\title{
Kernos
}

Revue internationale et pluridisciplinaire de religion grecque antique

16 | 2003

Varia

\section{Inventing Iphigeneia? On Euripides and the Cultic Construction of Brauron}

\section{Gunnel Ekroth}

\section{(2) OpenEdition \\ Journals}

Electronic version

URL: http://journals.openedition.org/kernos/811

DOI: 10.4000/kernos.811

ISSN: 2034-7871

\section{Publisher}

Centre international d'étude de la religion grecque antique

\section{Printed version}

Date of publication: 1 January 2003

Number of pages: $59-118$

ISSN: 0776-3824

\section{Electronic reference}

Gunnel Ekroth, «Inventing Iphigeneia? On Euripides and the Cultic Construction of Brauron », Kernos

[Online], 16 | 2003, Online since 14 April 2011, connection on 10 December 2020. URL : http:// journals.openedition.org/kernos/811 ; DOI : https://doi.org/10.4000/kernos.811 


\section{Inventing Iphigeneia?}

\section{On Euripides and the Cultic Construction of Brauron*}

The sanctuary of Artemis at Brauron on the east coast of Attica has long been thought to house a hero-cult, that of Iphigeneia. ${ }^{1}$ She has been connected with this site on the basis of literary evidence, which in its turn has led to the identification of certain structures as the tomb or the beroon of Iphigeneia and sections of other buildings as adapted to the particular needs of her cult.

The first aim of this paper is to evaluate the nature of Iphigeneia's presence at Brauron. It can be said from the outset that her cult at this site is not as clearly evidenced as is usually assumed. It is, in fact, possible to question to what extent Iphigeneia was a recipient of cult at this site altogether. Secondly, the wider methodological issue will also be of interest in this paper, namely the treatment and evaluation of literary versus archaeological evidence as source material for the study of Greek religion, in particular in the case of the identification and understanding of what a hero-cult is and how we are to recognize it. The notion of a cult of Iphigeneia at Brauron rests to a large extent on a passage in Euripides' Ipbigeneia among the Taurians (1462-1467). What follows here can be seen as an attempt to evaluate the validity of Euripides' statements. Instead of taking Euripides as confirming the evidence of an ancient cult of Iphigeneia at the site, it will be proposed that he may, in fact, have been the one who located her in Brauron in the first place.

The existence of a sanctuary at Brauron is well known from the ancient sources and the location of the site was identified as early as the late 19th century. ${ }^{2}$

I wish to thank Susanne Berndt-Ersöz, Kerstin Silfwerbrand, Ann-Louise Schallin and Berit Wells for valuable comments on earlier versions of this paper. Some of the aspects considererd here were presented at the Second Nordic symposium on women's lives in antiquity: Gender; culture and religion in antiquity at Helsinki, 20-22 October 2000, and the Eigbth international conference organized by the C.I.E.R.G.A. on Rbodes, 25-29 May 2001.

1 Whether Iphigeneia is to be regarded as a heroine or as a (facled) goddess, see below, n. 96. Such a classification seems to be more a question of modern definitions than a reflection of the ancient circumstances. She is usually included in surveys of hero-cult sites, see; for example, M. Deoud, Heroenkulte in homerischer Zeit, Oxford, 1999 (BAR IS, 806), p. 70-71; H. Abramson, Greek hero-shrines, Ph.D. Diss., University of California, Berkeley, 1978, p. 183-185. Here, I have followed the definition of a hero outlined in G. Eкrотн, The sacrificial rituals of Greek bero-cults in the Archaic to the early Hellenistic periods, Liège, 2002 (Kernos, suppl. 12), p. 20-22.

2 Hot., IV, 145; VI, 138; Paus., I, 23, 9; I, 33, 1; Рнот., s.v. Bpovpwvío (Theodoridis, B 264). Later sources use the name Brauron when referring to the whole deme, not just the sanctuary (e.g. Pomponius Mela, II, 46). The Classical deme, in which the sanctuary of Brauron was located, was Philaïdai, see D. Whitenead, The demes of Attica 508/7 - ca. 250 BC. A political and social study, Princeton, 1986, p. 24, n. 83; R. Osborne, Demos: The discovery of Classical Attica, Cambridge, 1985, 
Excavations were begun in 1948 under John Papadimitriou and continued until his death in 1963. During this period, annual reports appeared in Ergon and $\mathrm{BCH}$ and the excavator covered the excavation until 1959 in Praktika. ${ }^{3}$ He also wrote an extensive article, which appeared in Scientific American in $1963 .{ }^{4}$ Charalambos Bouras published the late-5th-century stoa in $1967 . .^{5}$ Parts of the ceramic material and the terracottas, as well as one major relief, have since been discussed by Lily Kahil. ${ }^{6}$ of particular interest are the inscriptions recovered from the site. Certain of these were briefly mentioned in Papadimitriou's reports and have also been commented upon by Dina Peppas-Delmousou, but they remain virtually unpublished. ${ }^{7}$ Some of the inscriptions, however, are said to be identical with texts deriving from the sanctuary of Artemis Brauronia on the Athenian Acropolis and these inscriptions, found in Athens and published in the $I G$, can therefore be used in the study of Brauron. ${ }^{8}$ In all, however, it has to be emphasized that dealing with Brauron entails proceeding with great care, since the excavation is still to a large extent known only from preliminary reports. The following discussion of Brauron and the cult of Iphigeneia may therefore be subject to many changes once the final publication of the site appears.

p. 193 and 215, fig. 12. For the earliest modern identifications of the sanctuary, see L. Ross, Arcbäologiscbe Aufsätze, vol. 1, Griechiscbe Gräber. Ausgrabungsbericbte aus Atben. Zur Kunstgeschichte und Topograpbie von Athen und Atlika, Leipzig, 1855, p. 222-229; A. MilchöfER, "Antikenbericht aus Attika", MDAI(A) 12 (1887), p. 291-292; cf. PAAH 1945-48, p. 81-84.

3 See Ergon 1955 , p. 33-34; 1956, p. 25-31; 1957, p. 20-22; 1958 , p. 30-39; 1959, p. 13-20; 1960, p. $21-$ $30 ; 1961$, p. $20-37 ; 1962$, p. $25-39 ; B C H 73$ (1949), p. $527 ; 74$ (1950), p. 298-300; 75 (1951), p. $110-111 ; 80$ (1956), p. 247; 81 (1957), p. 519-521; 82 (1958), p. 674-678; 83 (1959), p. 589-596; 84 (1960), p. 666-671; 85 (1961), p. 638-641; 86 (1962), p. 664-683; 87 (1963), p. 704-715; PAAH 1945-48 (pr. 1949), p. 81-90; 1949 (pr. 1951), p. 75-90; 1950 (pr. 1951), p. 173-187; 1955 (pr. 1960), p. 119-120; 1956 (pr. 1961), p. 7389; 1957 (pr. 1962), p. 42-47; 1958 (pr. 1965), p. 27; 1959 (pr. 1965), p. 19-20. See also J. Travlos,

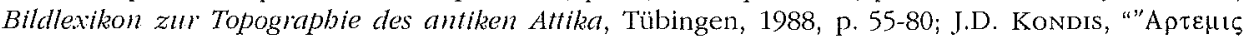
B poupwvía", AD 22 (1967), A, p. 156-206. The study by M. Giuman, La dea, la vergine, il sangue: Archaeologia di un cullo femminile, Milan, 1999 (Biblioleca di arcbeologia), reached me too late to be incorporated in this paper.

4 J. PApadimitriou, "The sanctuary of Artemis at Brauron", SciAm 208:6 (1963), p. 110-120.

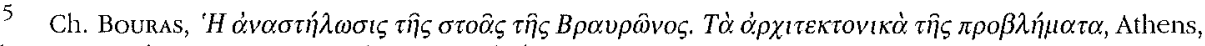

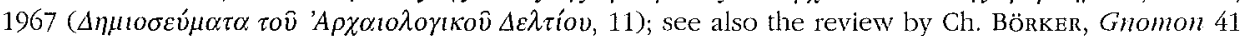
(1969), p. 802-806.

6 L. KaHIL, "Quelques vases du sanctuaire d'Artémis à Brauron", in Neue Ausgrabungen in Griecbenland, Olten, 1963 (AK Beibeft, 1), p. 5-29; Ead., "Autour de l'Artémis attique", AK 8 (1965), p. 20-33; Ead., "L'Artémis de Brauron: Rites et mystère", AK 20 (1977), p. 86-98; Ead., "Artemis", LIMC 2:1 (1984), p. 618-753; Ead., "Le relief des dieux du sanctuaire d'Artémis à Brauron. Essai d'interprétation", in J.-P. DEsceudres (ed.), EYMOY $I A$ : Ceramic and iconograpbic studies in bonour of Alexander Cambitoglou, Sydney, 1990 (Mediterranean Arcbaeology, suppl. 1), p, 113-117.

7 Papadimitriou, l.c. (n. 4), p. 118-120; Ergon 1958, p. 37; 1961, p. 21 and 24-26; PAAH 1949,

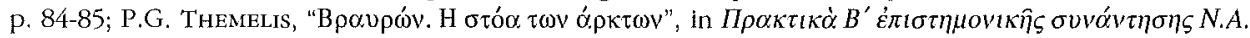

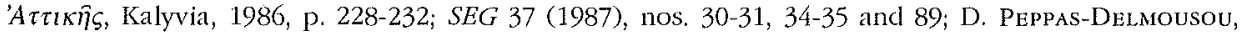
"Autour des inventaires de Brauron", in D. KNOEPFLER \& N. QuelLET (eds.), Comples et inventaires dans la cité grecque: Actes du colloque international d'épigrapbie tenu à Neuchâtel du 23 au 26 septembre 1986 en l'bonneur de Jacques Trébeux, Neuchâtel \& Geneva, 1988 (Université de Neucbâtel: Recueil de travaux publiés par la Faculté des Lellres, 40), p. 323-346; A.I. Antoniou,

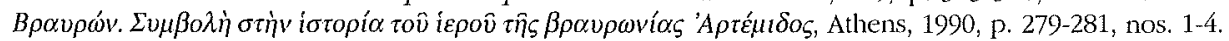

8 See $I G I^{2}, 15141525$ and 1528-1531; PAAH 1949, p. 84-85; 1956, p. 75-76; Ergon 1956, p. 28; $B C H$ 81 (1957), p. 521; 82 (1958), p. 300; T. Linders, Studies in the treasure records of Artemis Brauronia found in Athens, Stockholm, 1972 (ActaAtb-4ㅇ, 19), passim. 


\section{Iphigeneia at Brauron}

Myth clearly ties Iphigeneia to Aulis, where she was sacrificed by her father Agamemnon in order to procure favourable winds for the Greek fleet leaving for Troy. ${ }^{9}$ This story was told already in the 7th-century-BC Kypria by Stasinos and, according to the extant summary of the contents by Proklos as preserved in Photios, Artemis saved Iphigeneia, transported her to Tauris and made her immortal ( $\alpha \dot{\alpha} \alpha \alpha$ wov $\pi 01 \varepsilon \hat{\imath}) .{ }^{10}$ In the Hesiodic Catalogue of women, the girl was called Iphimede and after having been sacrificed and saved, she was given immortality and transformed into Artemis of the crossroads, i.e. Hekate. ${ }^{11}$ Both Aischylos and Sophokles mention the sacrifice of Iphigeneia at Aulis, but the story was particularly elaborated on by Euripides in the Ipbigeneia at Aulis. ${ }^{12}$

Her specific connection with Brauron is, however, less well documented. The most explicit source, which is also the earliest, is, in fact, Euripides. In his play Iphigeneia among the Taurians, Athena outlines the future relations of Iphigeneia and Orestes to two cults on the east coast of Attica. Orestes is to bring the cult image of Artemis Taurica back to Halai Araphenides and there to found a sanctuary of Artemis Tauropolos (IT, 1442-1461). Iphigeneia, for her part, is to be the priestess of Artemis at Brauron, where she is also to be buried after her death and receive as an offering the clothes of women who have died giving birth.

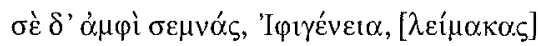

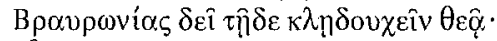

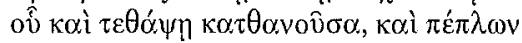

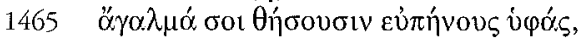

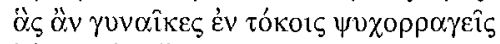

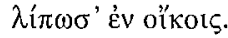

And you, Iphigeneia, in the holy meadows of Brauron must serve this goddess as her temple warder. When you die, you will lie buried here, and they will dedicate for your delight the finely woven garments which women who die in childbirth leave behind in their houses. ${ }^{13}$

9 For a summary and discussion of the sources, see F. Joun (ed.), Euripide. Tome VII ${ }^{1}$. Iphigénie à Aulis, Paris, 1983 (Collection des universités de France), p. 9-52; M.B. HollinsHEAD, "Against Iphigeneia's adyton in three mainland temples", A/A 89 (1985), p. 420-430; P. Brulé, La fille d'Atbènes. La religion des filles à Atbènes à l'époque classique. Mytbes, cultes et société, Paris, 1987 (Centre de recherches d'bistolre ancienne, 76), p. 180-203; K. DOwDEN, Deatb and the maiden: Girls' initiation riles in Greek mythology, London \& New York, 1989, p. 10-24; S. ArErz, Die Opjerming der Ipbigeneia in Aulis. Die Rezeption des Mytbos in antiken und modernen Dramen, Stuttgart \& Leipzig, 1999 (Beiträge zur Altertumskunde, 131), p. 47-229.

10 Proklos, Chrestomatbia (Allen, p. 104, 12-20); cf. Aretz, o.c. (n. 9), p. 47-51.

11 Fr. 23a, 17-26 and 23b (Merkelbach \& West); cf. STEsichoros, fr, $215(P M G)$. See also Hollinshead, l.c. (n. 9), p. 421, n. 5; Brulé, o.c. (n. 9), p. 182; Aretz, o.c. (n. 9), p. 60-61.

12 AEsch., Ag., 228-247; Soph., El, 537, 545 and 575-576; cf. JouAn, o.c. (n. 9), p. 12-14; ArETz, o.c. (11. 9), p. 62-86. At the beginning of the IT (1-31), Euripides gives a summary of Iphigeneia's role at Aulis. On the difficulties in the text of the $I A$ in which the sacrifice of Iphigeneia is outlined, see Jouna, o.c. (n. 9), p. 26-28; Id., "Autour du sacrifice d'Iphigénie", in Tente et image: Actes du colloque international de Chantilly (13 au 15 octobre 1982), Paris, 1984 (Centre de recherches de l'Universilé de Paris X), p. 61-74; Aretz, o.c. (n. 9), p. 110-114.

13 Eur., IT, 1462-1467, translation by D. Kovacs, Euripides, Trojan women. Iphigenia among the Taurians. Ion, Cambridge, Mass., \& London, 1999 (Loeb Classical Library). For the conjecture (line 
The rest of the information concerning Iphigeneia's presence at Brauron is to be found in the scholia to the Leiden MS of Aristophanes' Lysistrata. ${ }^{14}$

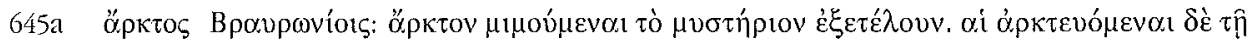

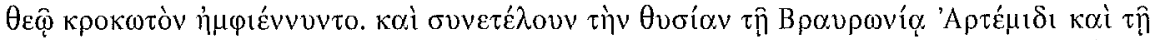

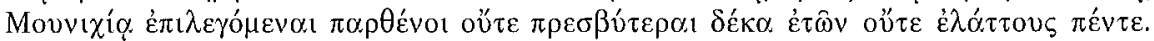

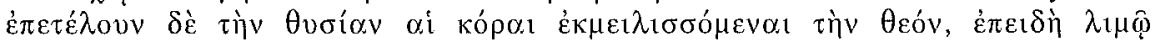

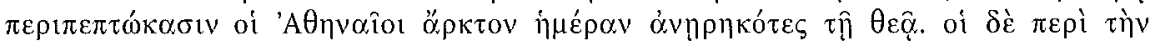

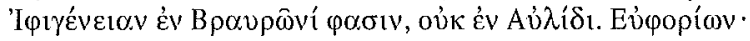

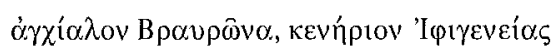

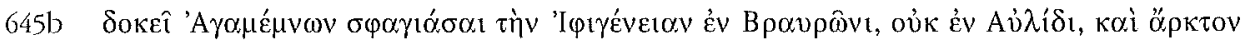

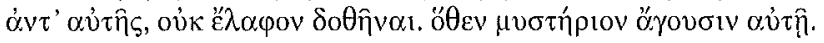

The main content of the scholion 645a-c concerns the cult of Artemis. At the end of 645a, however, it is stated that "what they say about Iphigeneia took place at Brauron, not at Aulis", i.e. referring to the story of her being sacrificed. As a support for this version, presumably, the scholiast quotes a line from the 3rd-century-BC writer Euphorion: "Brauron near the sea, the cenotaph of Iphigeneia". ${ }^{15}$ The next section of the scholion on the same line (645b) also explains that Agamemnon killed Iphigeneia at Brauron and not at Aulis and adds that she was replaced by a bear and not by a deer. Furthermore, a mysterion is celebrated to her there (i.e. to Iphigeneia at Brauron).

This is the extant evidence for Iphigeneia's presence at Brauron as given in the literary sources. The main problem concerns to what extent the information in the scholia, including the quotation from Euphorion, is to be regarded as providing evidence independently of Euripides, and therefore corroborating him, or whether these sources may have been influenced or inspired by the $I T{ }^{16}$ The information found in the various sources is not only of various dates and qualities but is also not entirely consistent, particularly when it comes to explaining why Iphigeneia was present at Brauron and what happened to her there.

However, the evidence for Iphigeneia's connection with Brauron is a little more complicated. Brauron was the seat of a ritual called the arkteia, probably performed on a penteteric basis and serving as an initiation into womanhood, during which young, Athenian girls stayed at the sanctuary. ${ }^{17}$ The aitia of the arkteia are complex

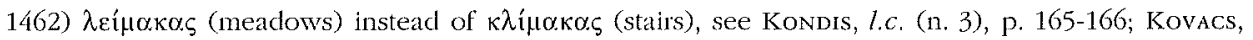
o.c., p. 307.

14 Schol. Ar., LyS., 645a-b (Hangard). This scholion is not preserved in the other MSS of the Lysistrata; for discussion and evidence, see W. SALE, "The temple-legends of the Arkteia", $R b M 118$ (1975), p. 265-284. The passage in Aristophanes concerns the chorus, describing its good educational background (Lys., 641-648) as a participant in various religious rites, among which was the Brauronia.

15 B.A. van Groningen, Eupborion, Amsterdam, 1977, no. 95. This line is also quoted by Nonnos, Dion. XIII, 186.

16 For Euripides' invention of cults or aspects of cults giving rise to a literary tradition in later sources rather than the later sources confirming Euripides' account, see S. Scullon, "Tradition and invention in Euripidean aitiology", ICS 24-25 (1999-2000), p. 222-223.

17 On the arkteia, see, for example, KaHIL (1965), l.c. (n. 6), p. 25-26; A. Brelich, Paides $e$ partbenoi, Rome, 1969 (Incumabula graecae, 36), p. 240-279; Ch. Sourvinou, "Aristophanes, Lysistrata, 641-647", CQ 65 (1971), p. 339-342; Kahil (1977), l.c. (n, 6), p. 86-98; A. Henrichs, "Human sacrifice in Greek religion: Three case studies", in J. RudHardT \& O. REverdin (eds.), Le sacrifice 
but can be said to concern the expiation for the killing of a bear sacred to Artemis. ${ }^{18}$ The goddess punished the Athenians with a plague, which was lifted by the execution of the instructions from Delphi to the Athenians to "sacrifice" their daughters to Artemis. This sacrifice was accomplished by letting the girls spend a period of time, probably less than a year, at her sanctuary. ${ }^{19}$ The culmination of this ritual has been suggested to have taken place during the Brauronia festival. ${ }^{20}$

What is the link between Iphigeneia and the arkteia, if any? There is, in fact, surprisingly little information on Iphigeneia's connection with this ritual at Brauron. It is interesting to note that Euripides seems to make no reference to the arkteia in the IT, when he outlines Iphigeneia's role at Brauron as a recipient of cult after her death. More explicit are the scholia to the Leiden MS of the Lysistrata which comment that a mysterion was performed to her. ${ }^{21}$ This mysterion has been taken to refer to the arkteia in some sense, since there are other testimonia speaking of the arkteia in similar terms. ${ }^{22}$ Still, it cannot be ruled out that the connection made in the scholion

dans l'antiquité, Geneva, 1981 (Entretiens sur l'antiquité classique, 27), p. 207-208; H. Luoyd-Jones, "Artemis and Iphigeneia", JHS 103 (1983), p. 92-93 and 97-98; P. PerLanan, "Plato Laws 833C-834D and the bears of Brauron", GRBS 24 (1983), p. 115-130; HollinsHeAd, l.c. (n. 9), p. 426-427; OsBorNe, o.c. (n. 2), p. 162-172; Brulé, o.c. (n. 9), p. 179-222; Ch. Sourvinou-Inwood, Studies $\mathrm{ll}$ gir/s transitions: Aspects of the arkteia and age representations in Attic iconography, Athens, 1988, passim; Dowden, o.c. (n. 9), p. 25-32; R. Hamilton, "Alkman and the Athenian arkteia", Hesperia 58 (1989), p. 449-472, esp. 459-462; Ch. Sourvinou Inwood, "Lire l'arkteia - lire les images, les textes, l'animalité", DHA 16:2 (1990), p. 45-60; Ch. Sourvinou-Inwood, "Ancient rites and modern constructs; On the Brauronian bears again", BICS 37 (1990), p. 1-14; P. BONNECHERE, Le sacrifice bumain en Grèce ancienne, Athens \& Liège, 1994 (Kemos, suppl. 3), p. 27-38.

18 Sourvinou-Inwood (1988), o.c. (n. 17); SAle, l.c. (n. 14); Hollinshead, l.c. (n. 9), p. 426-427.

19 For discussions on the age of the $a r k t o i$, suggestions ranging between five and ten years of age or ten to fourteen or fifteen, see Sourvinou-INwood (1988), o.c. (n. 17), p. 15 and 59-67; Sourvinou (1971), l.c. (n. 17), p. 339-342; T.C.W. STINTon, "Iphigeneia and the bears of Brauron", $C Q$ 70 (1976), p. 11-13; Perlman, l.c. (n. 17), p. 115-130; Hollinshead, l.c. (n. 9), p. 427; Dowden, o.c. (n. 9$)$, p. $28-31$.

20 For the Brauronia, see Ath. pol., 54.6; Ar., Pac., 873-874; schol. Ar., Pac., 874b (Holwerda). On its link with the arkteia, see L. Deubner, Attiscbe Feste, Berlin, 1932, p. 207-208; Sourvinou-Inwood (1988), o.c. (n. 17), p. 21; E. Simon, Festivals of Attica: An arcbaeological commentary, Madison, 1983 (Wisconsin Studies in Classics), p. 83-88; L. BoDson, "L'initiation artémisiaque", in J. Ries \& H. Limet (eds.), Les rites d'initiation: Actes du colloque de Liege et de Louvain-la-Nellve, 20-21 novembre 1984, Louvain-la-Neuve, 1986 (Homo religiosus, 13), p. 300-302; Dowden, o.c. (n. 9), p. 31; HAMILTON, l.c. (n. 17), p. 459-460.

21 The mysterion in the scholion presumably must be connected with Iphigeneia, although in the first part of the scholion (645a) a mysterion is said to be performed to Artemis.

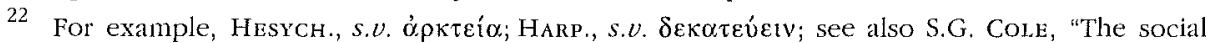
function of rituals of maturation: The koureion and the arkteia", $Z P E 55$ (1984), p. 240; Brulé, o.C. (n. 9), p. 184; cf. Osborne, o.c. (n. 2), p. 164-165; Sourvinou-Inwood (BICS 1990), /.c. (n. 17), p. 10-12. The mysterion is thought to be depicted on a red-figure krateriskos of the type connected with the arkteia. The scene shows Artemis and Apollon and a man and a woman with bear's heads or masks, taken by KAHIL ([1977] l.c. [n. 6], p. 86-98) to be the priestess and the priest at Brauron or a priestess and an acolyte; see Ead., "Le sanctuaire de Brauron et la religion grecque", CRAI 1988, p. 799-813. Others suggest that the scene shows the myth of Kallisto and Arkas (Simon, o.c. [n. 20], p. 87-88; Brulé, o.c. [n. 9], p. 255). To actually depict the central theme or action of a mysterion seems, however, to go against the whole idea of the secret character of such a ritual. Furthermore, there is no evidence for a priest of Artemis at Brauron. The inscriptions used to support such a notion (see, for example, B. Jordan, Servants of the gods: A study in the religion, history and literature of fiftb-century Athens, Göttingen, 1979 [Hypomnemata, 55], p. 33-34, and R.S.J. GARLAND, 
between the mysterion celebrated to Iphigeneia and the arkteia is a secondary development. These later sources may actually have conflated the arkteia and Euripides' version of the Iphigeneia legend.

The replacement of Iphigeneia by a bear instead of a deer at her sacrifice by Agamemnon has also been seen as a link between her and the arktoi of the arkteia. ${ }^{23}$ This variant of the story is, however, at the earliest evidenced in a post-Euripidean source and, more importantly, is there described as taking place at Aulis and not at Brauron. ${ }^{24}$

A further connection between Iphigeneia and the arkteia has been argued from language used in the description of her death at Aulis in the Agamemnon by Aischylos. Here, Iphigeneia is said to let her saffron-coloured dress (krokotos) slip to the ground before her being sacrificed, an action believed to echo the bears shedding the krokotos as part of the arkteia, as described in the Lysistrate by Aristophanes. ${ }^{25}$ The language used by both Aischylos and Aristophanes has been suggested to depend on ritual language and in the case of the Agamemnon to refer to Iphigeneia's role in the arkteia. ${ }^{26}$ However, since the krokotos was a bridal veil, it is possible that in Aischylos' play Iphigeneia was wearing the krokotos as a part of her preparation for the presumed marriage to Achilles. Aischylos may simply be applying the ritual terminology of the arkteia in order to allude to a ritual centring on the preparation of young girls for marriage without this necessarily implying that Iphigeneia actually formed part of this ritual at Brauron.

Finally, the most frequently evoked argument for Iphigeneia belonging to the arkteia has been to consider the structure of the Iphigeneia story as being paralleled by the aitia for the arkteia and therefore this ritual has been taken as an indication of Iphigeneia's presence at Brauron. ${ }^{27}$ On a general level, the expiation of the killing of the bear by the "sacrifice" of young girls can be said to be a counterpart to the story of Iphigeneia being sacrificed by her father in order to placate Artemis and to

"Religious authority in Archaic and Classical Athens", ABSA 79 (1984), p. 88-89), have been shown by Linders (o.c. [n. 8], p. 6) not actually to concern Brauron; cf. Bodson, l.c. (n. 20), p. 308.

23 Osbonne, o.c. (n. 2), p. 164; Brulé, o.c. (n. 9), p. 191-206; Ch. Wolff, "Euripides' Iphigeneia among the Taurians: Aetiology, ritual, and myth", ClAnt 11 (1992), p. 322-323.

24 See the 4th-century-BC writer Phanodemos, FGrHist, 325, F 14 (ap. Etym. Magn., s.u.

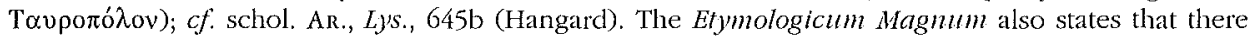
was a third version of this story, in which Iphigeneia was replaced by a bull. Bears are occasionally found as votive gifts in sanctuaries, but they were not exclusively dedicated to Artemis, as is shown by examples from the Argive Heraion and the sanctuary of Athena Alea at Tegea, see E. BEVAN, "The goddess Artemis, and the declication of bears in sanctuaries", ABSA 82 (1987), p. 17-21.

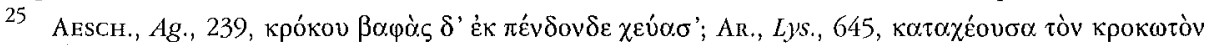

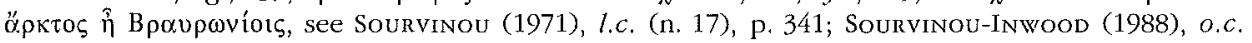
(n. 17), p. 132; Osborne, o.c. (n. 2), p. 164. For an alternative interpietation of the Agamemnon passage, see N.B. Воотн, "A further note on кро́коv ßo.фós in Aeschylus Ag. 239", Eranos 85 (1987), p. 64-65.

26 Sourvinou-Inwood (1988), o.c. (n. 17), p. 132-133; cf. D.D. Hughes, Himan sacrifice in ancient Greece, London \& New York, 1991, p. 84.

27 Sourvinou-Inwood (1988), o.c. (n. 17), p. 132; Ead. (DHA 1990), l.c. (n. 17), p. 52-53; Brulé, o.c. (n. 9), p. 179-222 and 249; Henrichs, l.c. (n. 17), p. 198-208; Lloyd-Jones, l.c. (n. 17), p. 91-96; Brelich, o.c. (n. 17), p. 242-246 and 277; Osborne, o.c. (n. 2), p. 162-169; Dowden, o.c. (n. 9), p. 9-47; L. KAHIL, "Iphigeneia", LIMC 5:1 (1990), p. 718-719; Hughes, o.c. (n. 26), p. 83-85; WolfF, l.c. (n. 23), p. 323; Bonnechere, o.c. (n. 17), p. 31-35; Scullion, l.c. (n. 16), p. 228; Aretz, o.c. (n. 9), p. 41-46, and 89. 
procure the desired winds. Although the replacement of the young girl by an animal victim occupies a central place in both stories, there are substantial differences. In the aetiological myths of the arkteia, the young girl interacts with the bear, presumably provoking it, and subsequently gets hurt, which leads to the bear being killed by her father, brothers or male members of the community, causing the anger of the goddess. In the case of Iphigeneia, she personally has no part in releasing the wrath of Artemis and she has no contact with any animal sacred to the goddess. It is Agamemnon who causes the divine hostility, either by acting with hubris or by killing a sacred animal. Futhermore, on a more concrete level, there is a great distinction between what the young girls did at the arkteia and what happened to Iphigeneia. The arkteia aimed at transforming the girls into marriageable young women and subsequently gynai, a process which can be said to be completed only when they had given birth to their first child. ${ }^{28}$ Though the pretext for Iphigeneia being brought to Aulis was marriage, her status at Brauron, as described by Euripides, the principal source of her presence at that site, was to serve the goddess, unmarried and without any children, at the sanctuary until her death. ${ }^{29}$ Therefore, it is difficult to perceive Iphigeneia as the direct prototype of the bears. ${ }^{30}$

One further problem in using the arkteia as an argument for Iphigeneia receiving a cult at Brauron is the fact that the ritual was not exclusively confined to this site but definitely also took place at the sanctuary of Artemis Mounychia in the Peiraieus, perhaps on a yearly basis. ${ }^{31}$ At Mounychia, the aitia for the ritual show many similarities to the aitia for the arkteia at Brauron and the stories are likely to have some connection, even though any certainty as to which one affected the other seems impossible, ${ }^{32}$ Of great interest in this context is a particular class of pottery considered to be connected with the arkteia: small, black-figure krateriskoi dated to the 6 th and the 5th centuries BC. They are decorated with scenes of running girls, altars and palm trees and are thought to show certain elements of the ritual. The function of the vases is unknown, but a red-figure sherd (c. 440-430 BC) found at Brauron shows an altar with a tumbling krateriskos in front of it, a scene which has been taken as evidence for these vessels being used for libations at the altar. ${ }^{33}$ A small number of krateriskoi show traces of ash inside and may perhaps have served as thymiateria. In any case, the krateriskoi were probably used for different purposes.

Quite a few krateriskoi have been found at Brauron and at Mounychia but they are also known from the sanctuary of Artemis Brauronia on the Athenian Acropolis,

28 DowDEN, O.c. (ก. 9), p. 201-202.

29 The aitia outlining the background of the arkteia does not comment upon the fate of the girl who was attacked by the bear.

30 On the distinctions between the a\%toi and Iphigeneia, see Sourvinou-INwoOD (1988), o.c. (n. 17), p. 52-54; E. Kearns, "The nature of heroines" in S. Blundell \& M. Williamson (eds.), Tbe sacred and the feminine in ancient Greece, London \& New York, 1998, p. 101. Iphigeneia being a prototype for the priestesses of Artemis at Brauron is also questionable, since some of these actually had children, see OsBorne, o.c. (n. 2), p. 160-161; Brulé, 0.C. (11. 9), p. 209.

31 On the arkteia at Brauron and Mounychia, respectively, see SALE, l.c. (n. 14), p. 265-284; Deubner, o.c. (n. 20), p. 204-208; E. KeArns, The beroes of Attica, London, 1989 (BICS, suppl. 57), p. 29-32; cf. Brelich, o.c. (n. 17), p. 245-256; Aretz, o.c. (n. 9), p. 44-45.

32 For possible lines of development, see SALE, l.c. (n. 14), p. 265-284; Henrichs, l.c. (n. 17), p. 199-203; Brulé, o.c. (n. 9), p. 182-186; DOWDEN, o.c. (n. 9), p. 20-23.

33 Kahil (1963), l.c. (n. 6), p. 25-26, no. 56 and pl. 14:3; Ead. (1977), l.c. (n. 6), p. 88; Ead., l.c. (n. 22), p. 806; Sourvinou-INwOOD (BICS 1990), l.c. (n. 17), p. 13. 
the sanctuary of Artemis Agrotera at Athens, the Athenian Agora and the cave of Pan and the Nymphs at Eleusis, though only in small numbers. ${ }^{34}$ The sanctuary of Artemis at Halai Araphenides seems to have yielded more of this particular kind of pottery. ${ }^{35}$

The spread of this class of pottery has been taken as an indication of the arkteia being widely practised. ${ }^{36}$ The differences in the quantities of krateriskoi found at Brauron and Mounychia, on the one hand, and at the other sites, on the other, are significant. Therefore, it seems more plausible to assume that, while the ritual was actually practised at Brauron and Mounychia, findings of krateriskot at other sanctuaries may be seen as dedications commemorating the participation in the arkteia at either of these two former sites or simply as dedications marking that the arkteia age had passed. ${ }^{37}$ In any case, the distribution of the krateriskot at such a number of sanctuaries actually weakens the link between Iphigeneia and the arkteia, since none of the other find-spots can be shown to have had any certain cultic connection with her. ${ }^{38}$

Most importantly, there is no connection between Iphigeneia and the sanctuary of Artemis at Mounychia. Even though the killing of a bear and a young girl either being hurt or sacrificed are part of the myth, both at Mounychia and at Brauron, that is not enough to postulate Iphigeneia's presence also at Mounychia. It has been suggested that the Mounychia arkteia may have been taken over from Brauron, but, if Iphigeneia formed part of this ritual, we then have to assume that she got lost on the way. ${ }^{39}$ Altogether, however, it seems equally possible that Iphigeneia was not a

34 Brauron and general: KAHI. (1965), l.c. (n. 6), p. 20-33, Ead., l.c. (n. 22), p. 804-805, all blackfigure examples; $c f$. Brulé, o.c. (n. 9), p. 250-256; Dowden, o.c. (n. 9), p. 31-34; Hamilton, 1.c. (n. 17), p. 449-472. The Athenian Acropolis and the Agora: L. KAHIL, "Le 'cratérisque' d'Artémis et le Brauronion de l'Acropole", Hesperia 50 (1981), p. 253-263. Mounychia: L. Palaiokrassa, "Neue Befunde aus dem Heiligtum der Artemis Munichia", AM 104 (1989), p. 1-40; L. Palaiokrassa, Tò iepó

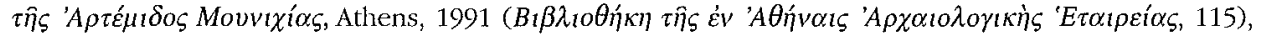
p. 74-82 and 147-162; Hamilton, l.c. (n. 17), p. 449-472. Three red-figure krateriskot of unknown provenience showing ritual scenes are also known; see KaHIL (1977), l.c. (n. 6), p. 86-98.

35 The krateriskoi were found in connection with a small building with a porch and a back room c. $200 \mathrm{~m}$ to the south of the main temple. Recovered were also figurines, jewellery and

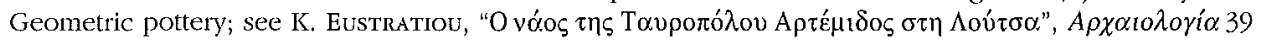
(1991), p. 73.

36 Cole, l.c. (n. 22), p. 242. Sinon (o.c. [n. 20], p. 86) thinks that all sanctuaries with krateriskoi also housed the arkteia, since all are sanctuaries of Artemis. She "fails" to mention the cave of Pan, however.

37 See Sourvinou-Inwood (1988), o.c. (n. 17), p. 116, who also argues that these sanctuaries are too disparate for all of them to have been the seats of the arkteia. If the krateriskoi were commemorative dedications, their spread and use can be seen as similar to that of Panathenaic prize amphorai.

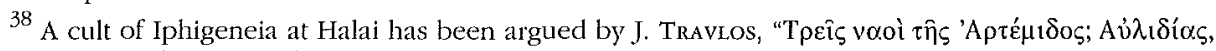

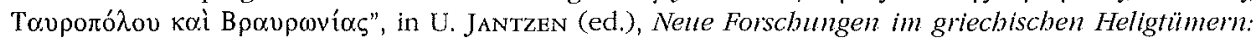
Intemationalen Symposion in Olympia vom 10. bis 12. Oktober 1974 anlässicb der Hundertjabrfeier der Abteilung Atben und der deutschen Ausgrabungen in Olympia, Tübingen, 1976, p. 197-205; Kahil (1977), l.c. (n. 6), p. 96; Brulé, o.c. (n. 9), p. 192-200. See, however, the arguments against this suggestion presented by HollinsHEAD, l.c. (n. 9), p. 427-428 and 435-438.

39 On Iphigeneia being absent from the cult of Artemis Mounychia, see L. KaHIL, "Artémis et Iphigénie: Artémis, les enfants et les animaux", in Tranquilitas: Mélanges en l'bonneur de Tran tam Tinb, Quebec, 1994 (Collection Hier pour aujourd'bui, 7), p. 284. For suggestions as to how the traditions at Brauron, Mounychia and Aulis may have developed and affected each other, see SALE, 
basic component of the arkteia. We may, in fact, be dealing with an early aition for the ritual consisting of a young girl and a bear, onto which at Brauron the Iphigeneia story has been grafted, since certain similarities in the stories facilitated such a match. ${ }^{40}$

On the basis of the evidence outlined above, and chiefly Euripides, the excavator of Brauron, John Papadimitriou, identified a series of structures in a cave or cleft to the south-east of the temple of Artemis as the tomb or beroon of Iphigeneia (Fig. 1, no. 7, and Figs. 2-3). ${ }^{41}$ The roof of this cave collapsed in the mid-5th century BC and the structures within were subsequently replaced by a small building at the northwestern entrance of the former cave (Fig. 1, no. 6, and Fig. 3). Papadimitriou's two main arguments for locating the tomb of Iphigeneia on this spot were the finding of four graves in the area, interpreted as the burials of later priestesses of Artemis, and his claim that a cave was particularly suitable for Iphigeneia, since heroes were often said to receive worship in caves. ${ }^{42}$

In the Iphigeneia among the Taurians, Euripides further stated that Iphigeneia was to be given the clothes of women who had died in childbirth. ${ }^{43}$ A shallow stoa situated along an open courtyard in the northern section of the great stoa at Brauron has been suggested to have housed these textile offerings, displayed on wooden boards placed in stone bases (Fig. 1, no. 12, and Figs. 4-5) ${ }^{44}$ This back part of the stoa, where the clothes allegedly were housed, only communicated with the central part of the sanctuary by a narrow passage, an arrangement suggested to be appropriate for the apotropaic character of these offerings, as well as for the negative and death-associated cult of Iphigeneia, which was separated from the more positive and life-embracing cult of Artemis. ${ }^{45}$

Iphigeneia's presence has also been recognized in the layout of the temple of Artemis (Fig. 1, no. 1). The cella of the temple had an adyton, a feature which has been considered as characteristic of the worship of a chthonian divinity, whose cult had to be set off and separated from the more public sphere of the rest of the sanctuary. ${ }^{46}$

l.c. (n. 14); DowDEN, o.c. (n. 9), p. 20-24. There is, however, neither literary nor archaeological evidence for a cult of Iphigeneia at Aulis; see Hollinshead, l.c. (n. 9), p. 423-424.

40 On arkteia being an old ritual, see Osborne, o.c. (n. 2), p. 163; K. Dowden, "Myth: Brauron and beyond", DHA 16:2 (1990), p. 33-36 and 42; cf. Id., o.c. (n. 9), p. 194-197.

41 PAAH 1955, p. 118-119; PAAH 1956, p. 75-77; PAAH 1957, p. 42-45; Ergon 1956, p. 25-28; Ergon 1957, p. 20-22; Papadimitriou, l.c. (n. 4), p. 113-115.

42 See PAAH 1955, p. 118-119 and pl. 38 a; PAAH 1956, p. $76-77$ and pl. 19 g; Ergon 1956, p. 27; Ergon 1957, p. 22; Papadimitriou, l.c. (n. 4), p. 115; for the burials, see further below, p. 77-78. Papadimitriou provided no evidence to support his assertion of the connection between heroes and caves.

43 EuR., IT, 1464-1467.

44 Ergon 1961, p. 29; Kondis, l.c. (n. 3), p. 173-175; Bouras, o.c. (n. 5), p. 122 and 182; Cole, l.c. (n. 22), p. 239; cf. Travlos, o.c. (n. 3), p. 55.

45 Kondis, l.c. (n. 3), p. 161-162 and 174-175.

46 Travlos, l.c. (n. 38), p. 197-205; cf. L. Kahil, "La déesse Artémis : Mythologie et iconographie", in J.N. Coldstream \& M.A.R. Colledge (eds.), Greece and Italy in the Classical world: Acta of the XItb Intemational Congress of Classical Arcbaeology. London, 3-9 September 1978, London, 1979, p. 77; Ead. (1977), l.c. (n. 6), p. 95-96; Brulé, o.c. (n. 9), p. 193-195; DOWden, o.c. (n. 9), p. 38; Kahil, l.c. (n, 27), p. 716; H. Lohmann, "Brauron", Nelue Pauly 2 (1997), p. 763. 


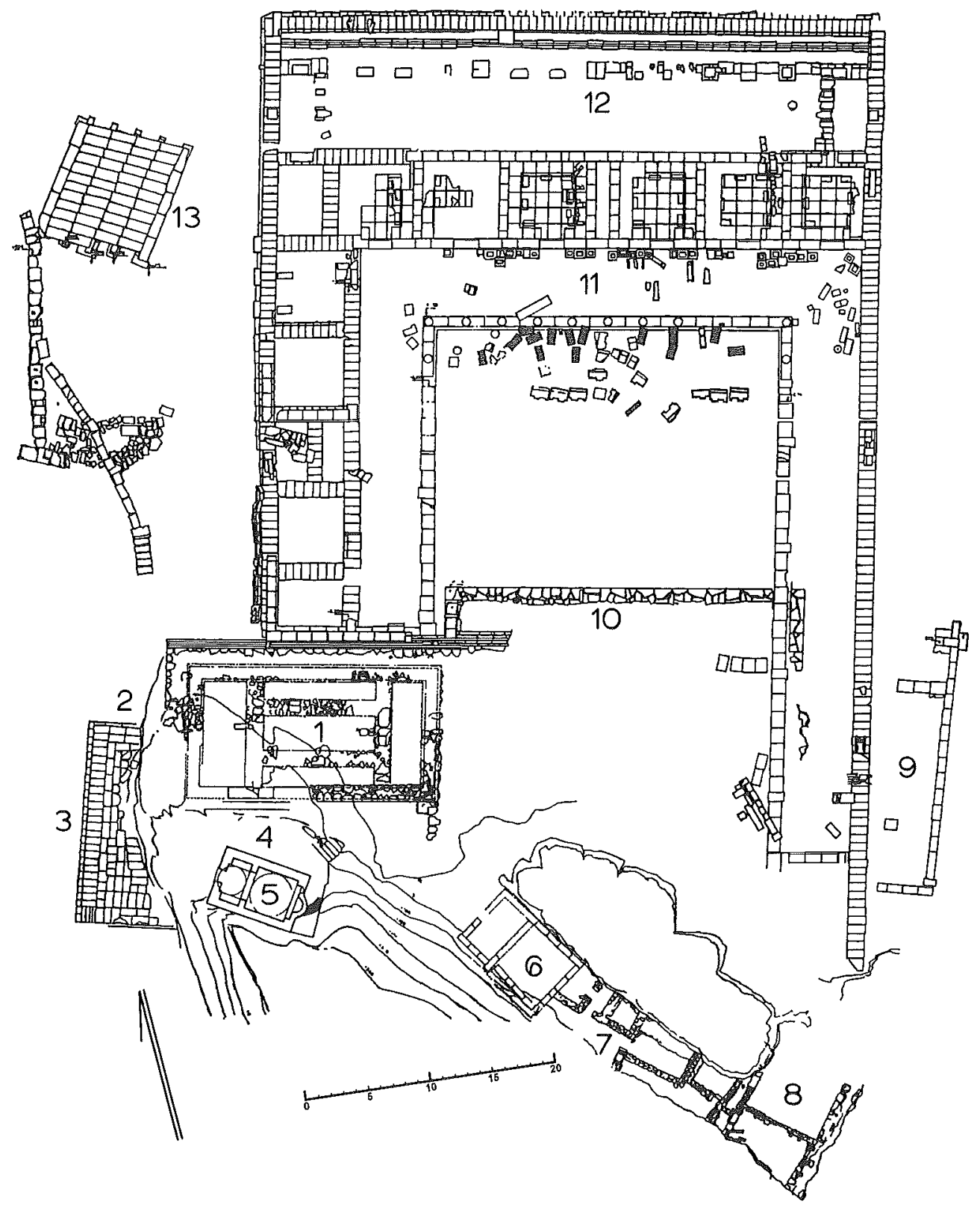

Fig. 1. Plan of the sanctuary of Artemis at Brauron (including both Archaic and Classical phases). From Bouras, o.c. (n. 5), fig. 1.

1. Temple of Artemis; 2. Spring; 3. Western terrace; 4. Rock-cut terrace; 5. Chapel of Ag. Georgios; 6. "Small Temple"; 7. Buildings within the cave area; 8. "Sacred House"; 9. Eastern building; 10. Polygonal terrace; 11 . Great stoa; 12 . Northern section of the stoa; 13 . Bridge. 
It is interesting to note that the linking of these archaeological remains with Iphigeneia is based not only on the written sources but also on the argument that she, as a heroine, had a chthonian character distinct from that of Artemis, who belonged to the Olympian sphere. What the literary sources tell us about the cult and rituals of Iphigeneia at Brauron has been interpreted along the lines of what is commonly assumed in the scholarly literature to be typical of a chthonian divinity and from this follows the assumption that the cult of chthonian divinities took certain expressions and that these are traceable in the archaeological record.

The division of Greek religion into an Olympian and a chthonian sphere is an approach which has gradually come to be questioned, most of all, since what constitutes the Olympian and the chthonian respectively seems to be more of a literary construct, both ancient and modern, than a basic feature of practised, ancient Greek cult. ${ }^{47}$ A further complication is the fact that many of the typically chthonian traits seem to be absent from the archaeological record. ${ }^{48}$ This should be kept in mind when studying the cult of Iphigeneia at Brauron.

\section{The archaeology of Iphigeneia}

The identification of the cave and its structures with the burial place of Iphigeneia mentioned by Euripides and of the northern section of the stoa and the adyton as connected with her cult have been more or less unanimously accepted among scholars. ${ }^{49}$ And is there, in fact, any reason for doubt? The starting-point in this identification has been to apply the literary sources to the archaeological evidence. To base the evaluation of Iphigeneia chiefly on the literary sources may seem to be the only course of action, since the archaeological material is still to a large extent only accessible from preliminary reports. ${ }^{50}$ On the other hand, the archaeological

47 See, for example, R. SCHLEsiEr, "Olympian versus Chthonian religion", SCI 11 (1991-92), p. 3851; F.T. van STRATEN, Hierà kalá. Images of animal sacrifice in Archaic and Classical Gieece, Leiden, 1995 (Religions in the Graeco-Roman world, 127), p. 165-167; K. Clin'Ton, "A new lex sacra from Selinus: Kindly Zeuses, Eumenides, impure and pure Tritopatores, and elasteroi", $C P b 91$ (1996), p. 159-179; Eкroth, o.c. (n. 1), passim. See also S. Scullion, "Olympian and chthonian", ClAnt 13 (1994), p. 75-119.

48 See, for example, the use and meaning of the terms eschara and botbros discussed in EкRотн, o.c. (n. 1), p. 23-74; Ead., "Altars in Greek hero-cults: A review of the archaeological evidence", in R. Ḧ̈GG (ed.), Ancient Greek cult-practice from the arcbacological evidence. Proceedings of the Fourth International Seminar on ancient Greek cult, organized by the Suedish Institute at Atbens, 22-24 October 1993, Stockholm, 1998 (ActaAtb-8', 15), p. 117-130; Ead, "Altars on Attic vases: The identification of bomos and eschara", in Ch. Scheffer (ed.), Ceramics in context: Proceedings of the Internordic colloquim on ancient pottery beld at Stockholm, 13-15 June 1997, Stockholm, 2001 (Stockbolm Studies in Classical Archaeology, 12), p. 115-126.

49 Kondis, l.c. (n. 3), p. 166; P.G. Themelis, Brawron: Fübrer durch das Heiligtum und das

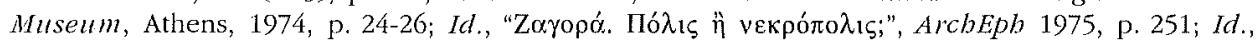
Frïhgriecbiscbe Grabbauten, Mainz am Rhein, 1976, p. 53; Abramson, o.c. (n. 1), p. 183-185; KahlL (1977), l.c. (n. 6), p. 96; Ead., "Mythological repertoire of Brauron", in W.G. Moon (ed.), Ancient Greek art and iconography, Madison \& London, 1983 (Wisconsin Studies in Classics), p. 232; Osborne, o.c. (n. 2), p. 156 and 164; Travlos, l.c. (n. 38), p. 198; Garland, l.c. (n. 22), p. 88-89; Bodson, l.c. (n. 20), p. 306; Brulé, o.c. (n. 9), p. 179; Travlos, o.c. (n. 3), p. 55; Dowden, o.c. (n. 9), p. 25,38 and 45 ; Hughes, o.c. (n. 26), p. 83.

50 For a certain scepticism towards the literary sources, see HollinsHEAD, l.c. (n. 9), p. 425; J. Mylonopoulos \& F. Bubenheimer, "Beiträge zur Topographie des Artemision von Brauron", $A A$ 1996, p. 15-16; Deoudi, o.c. (n. 1), p. 70-71. 
material so far known from Brauron offers such a variety of evidence (architectural remains, sculpture, pottery and other votive objects) that it seems fruitful at least to attempt the opposite procedure, namely to see whether archaeology can throw any light on the literary sources. Furthermore, it is also of interest to evaluate the archaeological material on its own conditions within its own particular context, both in relation to Brauron itself and in relation to Greek sanctuaries at large.

Are, in fact, the role and function ascribed to Iphigeneia on the basis of the literary sources really reflected in the archaeological material? A closer look at the evidence reveals that there are a number of problems, both in connection with Iphigeneia's presence at Brauron and with the identification of the cave area, the northern, back section of the stoa and the adyton of the temple as related to her cult. Most of all, if these areas and structures were connected with Iphigeneia, she must be considered to have been a major recipient of worship at the site. As such, she would be expected to be highly visible in the rest of the material record recovered from Brauron, such as votive offerings, inscriptions and iconography, and not only in the architecture. This, however, does not seem to be the case.

First of all, as far as we can tell today from the material known from Brauron, there is not a single mention of her name on any object found at the site. ${ }^{51}$ Even though the finds and the inscriptions remain largely unpublished, a number of dedications to Artemis are known on pottery, bronze objects and statue bases. ${ }^{52}$ Many of the unpublished stone inscriptions from Brauron seem to comprise of lists of offerings, mainly of clothes and jewellery. In the 4th century BC, copies of these inscriptions were housed in the sanctuary of Artemis Brauronia on the Acropolis and in these texts, published in the $I G$, Iphigeneia does not figure either. There are, however, a number of mentions of Artemis. ${ }^{53}$ It is, of course, possible that Iphigeneia will surface once the material is fully published, but it seems strange that, if she had been mentioned in any of the inscriptions or on any of the votives, Papadimitriou would have failed to comment that this was the case. ${ }^{54}$

Recently Sarah Johnston has argued that offerings to Iphigeneia are, in fact, to be found in the inventory inscriptions, though Iphigeneia herself is not named. Among the votive gifts, these texts list unfinished clothes and those are to be identified with the dedications from the dead women mentioned by Euripides. Johnston suggests that, when the women died, their unfinished weavings still in the loom would be dedicated at Brauron. ${ }^{55}$ This is an interesting proposal, but there is no evidence in

51 Hollinshead, l.C. (n. 9), p. 425.

52 Inscribed bronze mirror: Ergon 1961, p. 33 and 28, fig. 28; BCH 86 (1962), p. 676 and 679, fig. 11 (with Daux's corrections of the inscription); SEG 37 (1987), no. 45. Two stone pillars: R. OsbornE, Classical landscape with figures. The ancient Greek city and its countryside, London, 1987, p. 82, fig. 25; SEG 37 (1987), no. 137. Dedication on a stone base: BCH 83 (1959), p. 596 and 597, fig. 29. Pottery: PAAH 1949, p. 90.

53 See, for example, $I G \mathrm{II}^{2}, 1514,40-41(=1515,26-28 ; 1516,13-14) ; 1514,40-41,69$ and $52-53$. It is also interesting to note that Apollon is mentioned in one of the inscriptions recovered at Brauron, see Ergon 1958, p. 37; Peppas-Delmousov, l.c. (n. 7), p. 330-334; SEG 37 (1987), nos. 30 and 31.

54

4 Particularly so, since he mentions dedications to Artemis, see supra, n. 52. When Papadimitriou occasionally speaks of offerings or inscriptions to Artemis-Iphigeneia this is not to be taken as an indication of her name occurring at the site, since he considered Artemis to be identified with Iphigeneia at Brauron (1.c. [n. 4], p. 113).

55 S. Johnston, Restless dead: Encounters between the living and the dead in ancient Greece, Berkeley, 1999, p. 238-241; cf. Cole, l.c. (n. 22), p. 239; Brulé, o.c. (n. 9), p. 230. Dedications 
Euripides' text that the clothes he speaks of were unfinished. The poet simply states that the clothes are those that the women left behind in their houses: there is no mention of any looms or the actual weaving of cloth. Johnston states that Iphigeneia will receive as her agalma "fine-textured weavings, which women who die in childbed have left behind in their homes". ${ }^{56}$ This translation fails to account for the word $\pi \dot{\varepsilon} \pi \lambda \omega v$, "garments" (line 1464), and therefore gives the impression that Euripides was speaking of clothes still in the making, i.e. weavings. However, the

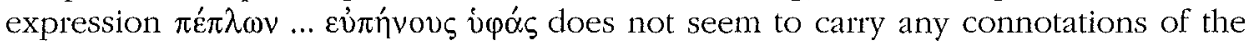
object in question being "unfinished", at least not in Euripides. The same wording is found also elsewhere in the same drama, where it refers to Pylades using his peplon eupenos byphas to shield Orestes from an attack by armed herdsmen. ${ }^{57}$ It seems strange that the terms used to describe a garment strong enough to withstand a violent assault are also to be understood as implying that a piece of clothing had not been finished and consisted more or less of weavings.

Another argument against identifying the unfinished textiles in the inscriptions with the garments that Euripides claims were dedicated to Iphigeneia is the fact that the offering of unfinished or even new clothes is contrary to the regular practice in textile dedications in Greek sanctuaries. The textiles given to Artemis, both at Brauron and elsewhere, were usually clothes that had been worn and in the Brauronian inscriptions the one object that was new is explicitly pointed out. ${ }^{58} \mathrm{~A}$ more plausible explanation of the unfinished items was put forward by Tullia Linders in her commentary on the inscriptions. ${ }^{59}$ Since the unfinished clothes in some cases

specified as unfinished: $I G \mathrm{II}^{2}, 1514,53-54(=1516,30 ; 1517,160-161)$, chitoniskos; 1514, 59 (= 1516, 35; 1518, 76; PAAH 1949, p. 85, line 3), cbitonion; 1514, $72(=1516,45 ; 1518,91)$, unknown garment and woof; $1518,53-54(=1524,162-163)$, woollen web, wool and woof; $1518,67-68$, bimation and wool; 1522, 26, tarantinon; 1524, 213, chitoniskos; 1524, 231, unknown garment; 1524, 234, pteryx.

56 Johnston, o.c. (n. 55), p. 238.

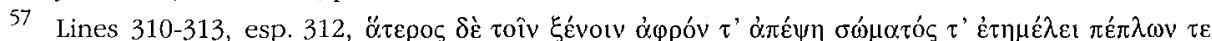

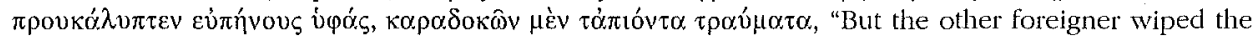
foam from his face, protected his body, and shielded him with the thick weave of his garments, anticipating the blows as they fell"; transl. Kovacs, o.c. (n. 13). See also Wolfr, l.c. (n. 23), p. 319,

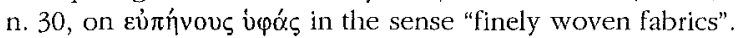

58 On the dedication of worn clothes, see Linders, o.c. (n. 8), p. 13; Brulé, o.c. (n. 9), p. 226-236; Kondis, l.c. (n. 3), p. 160-161; W.H.D. Rouse, Greek votive offerings: An essay in the bistory of Greek religion, Cambridge, 1902, p. 252. A newly found relief from Lamia shows the garments being displayed; see F. Dakoronia \& L. Gounaropoulou, "Artemiskult auf einem neuen Weihrelief aus Achinos bei Lamia", MDAl(A) 107 (1992), p. 217-227; cf. van STraten, o.c. (n. 47), p. 82-83. See also Anth. Pal., VI, nos. 200-202, 270-272 and 274; schol. Call., Hymm. I. In Iovem, 77-78; Hipp., De virg. morb., 468 (Littré, vol. 8, 1853); W. Günther, "Vieux et inutilisable' dans un inventaire inédit de Milet", in D. Knoepfler \& N. Quellet (eds.), Comples et inventaires dans la cité grecque: Actes du colloque international d'épigraphie tenu à Neuchâtel du 23 au 26 septembre 1986 en l'bonneur. de Jacques Trébeux, Neuchâtel \& Geneva, 1988 (Université de Nelıchâtel: Recuell de travaux publiés par la Faculté des Lettres, 40), p. 215-237, esp. 229-232 (2nd-century-BC inscription from Miletos listing a number of worn and tattered clothes); H. KNackruss, Milet I:7: Der Südmarkt und die benacbbarten Bauanlagen, mit eptgrapbiscbem Bettrag von Albert Rebm, Berlin, 1924, p. 287290, no. 202 = F. Sokolowski, Lois sacrées de l'Asie Mineure, Paris, 1955 (École française d'Athènes: Travaux et mémoires, 9), no. 51 (Lex sacra of Artemis Kithone, end of the 1st century BC). On the epiblema (coverlet) recorded as new in the Brauronian inscriptions, see $I G \mathrm{II}^{2}, 1514,30-32$.

59 Linders, o.c. (n. 8), p, 17-19; cf. Kondis, l.c. (n. 3), p. 189. Cf. the epinetra recovered from Brauron (KAHIL [1963], l.c. [n. 6], p. 12-13, nos. 21-24 and pl. 5), as well as the listing of weaving implements in the inscriptions, see Kondis, l.c. (n. 3), p. 189-190. For dedications of woof and wool, see supra, n. 55. 
occur together with woof and wool, she suggested they are to be seen as symbolic dedications to Artemis in her aspect as a protector of handicraft and weaving.

Secondly, apart from Iphigeneia's name not occurring in the material connected with Brauron, there seem to be no indisputable representations of her from the sanctuary. ${ }^{60}$ As Lily Kahil comments, on aimerait retrouver Ipbigénie sur les images de Brauron. ${ }^{61}$ The site has yielded a number of high-quality votive reliefs, some of which show worshippers approaching the divinity, which in all cases can be identified as Artemis. ${ }^{62}$ There are also a few examples of stone sculptures representing Artemis. ${ }^{63}$ The best candidate for a depiction of Iphigeneia is a relief from $c$. 400-350 BC showing a series of divinities (usually called the "Relief of the gods"). ${ }^{64}$ Seen from the left are a seated male, a standing female, a standing male and a running female. The right-hand part of the relief is missing, but to the left of the break are preserved the hoofs of two deer most likely pulling a chariot. A female head, presumably belonging to the figure riding the chariot, was also recovered.

The seated male is probably Zeus and the next two figures are usually identified as Leto and Apollon. ${ }^{65}$ Kahil, who published the relief, suggested that the missing character in the right-hand part of the relief riding the chariot drawn by deer was to be identified with Artemis, while the running figure just to the left of the break was Iphigeneia. ${ }^{66}$ Since there are no inscriptions naming the divinities shown, other candidates can also be argued for. In fact, Kahil does not exclude the possibility that the running figure is Hekate, with whom Iphigeneia was closely connected and even transformed into, according to one literary tradition. ${ }^{67}$

60 Iphigeneia's iconography at large is fairly restricted and concentrated in two types, neither of which is cultic nor relates to Bratron: (1) the Greeks' departure from Aulis (mainly Greek representations) and (2) Iphigeneia as a priestess at Tauris (mainly South Italian renderings, more or less inspired by Euripides' IT), see KaнIL, l.c. (n. 27), p. 708-718, esp. 717-718; Ead., "Le sacrifice d'Iphigénie", MEFRA 103 (1991), p. 183-196; Ead., l.c. (n. 22), p. 809-812.

61 KAHIL, l.c. (n. 22), p. 809.

62 Ergon 1958, p. 34-35, figs. 36-37; Ergon 1959, p. 17, fig. 18; van Straten, o.c. (n. 47), nos. R73-74; KAHIL (1984), l.c. (n. 6), nos, 234, 459, 463, 621, 673, 724, 974, 1036 a and 1127, clating from the late 5 th to the late 4 th century $\mathrm{BC}$.

63 KAHIL (1984), l.c. (n. 6), no. 140 (Hellenistic) and no. 361 (late 4th to late 3rd century); cf. no. 118, a statue of a young man holding an archaizing representation of Artemis (c. $330 \mathrm{BC}$ ). See also the bronze spbyrelaton figure, presumably of Artemis (late 7 th to early 6th century BC), ibid., no. 80 .

64 On the relief, see Ergon 1958, p. 35 and fig. 35; PApadinitriou, l.c. (n. 4), p. 120; KAHL (1990), l.c. (n. 6), p. 113-117; Ead., l.c. (n. 46), p. 79; Ead, l.c. (n. 27), no. 1225.

65 Papadimitriou, l.c. (n. 4), p. 120; Kahil (1990), l.c. (n. 6), p. 113-114; Themelis (1974), o.c. (n. 49), p. 58. As a less likely identification, Papadimitriou also suggested that the figures were Poseidon, Athena, Orestes and Iphigeneia; see Ergon 1958, p. 35.

66 Kahil (1990), l.c. (n. 6), p. 114-117; Ead, l.c. (n. 27), p. 716, no. 33, and p. 719; Ead., l.c. (n. 22), p. 809-812; Ead. (1984), l.c. (n. 6), no. 1225; Ead., l.c. (n. 49), p. 235. Themelis ([1974], o.c. [n. 49], p. 58) has proposed that the woman in the chariot was Iphigeneia and that the running female figure next to Apollon was Artemis. This seems improbable, since Iphigeneia would in this case be given a more prominent position than Artemis, who was undoubtedly the main divinity of Brauron.

67 KaHIL (1990), l.c. (n. 6), p. 116-117; Ead., l.c. (n. 27), p. 716, no. 33, and p. 719; H. SARIAN ("Hekate", LIMC 6:1 [1992], p. 993, no. 49) interprets the figure as Hekate, suggested to be Iphigeneia. The figure was probably holding a torch, a common attribute of Hekate. The Iphigeneia-Hekate merger, which was effectuated by Artemis, is mentioned in a fragment of 
The lack of clear iconographical evidence for Iphigeneia's presence is the more surprising considering the fact that representations of a number of other divinities have been found at Brauron. ${ }^{68}$ Zeus, Apollon, Leto and Hekate are most likely shown on the relief mentioned above. Apollon and Leto are also depicted, together with Artemis, on another votive relief. ${ }^{69}$ Hekate is present in the shape of a small, archaizing, trimorphous statue and the lower part of a small statue of Kybele has also been discovered at the site. ${ }^{70}$ Finally, several fragments of a large, cylindrical altar, discovered north of the temple, bear a relief showing Dionysos, Hermes, Eirene and Leto approaching Ariadne seated on a rock. ${ }^{71}$ It is, of course, possible that some of the female terracotta figurines and terracotta plaques and pinakes found at many places in the sanctuary may represent Iphigeneia, but they may just as well show Artemis or perhaps even the female dedicants themselves, since this was a sanctuary catering for women in particular. ${ }^{72}$

Altogether, Iphigeneia is curiously absent from Brauron. This fact has already been remarked upon and the most common remedy has been to view Iphigeneia as more or less united with Artemis and therefore not very visible in any sense. The connection between Iphigeneia and Artemis is not unique to Brauron but is

Stesichoros (fr. 215 PMG) and in Hesiod's Catalogue of women quoted by Pausanias (I, 43, 1); see also discussion by Johnston, o.c. (n. 55), p. 241-249; Hollinshead, l.c. (n. 9), p. 421-422.

68 Still, the iconography of Brauron, as compared with other sanctuaries, is unusually centred on Artemis, according to L. KAHIL, "Artémis en relation avec d'autres divinités à Athènes et en Attique", in Texte et image: Actes du colloque international de Cbantilly (13 au 15 octobre 1982), Paris, 1984 (Centre de recherches de l'université de Paris X), p. 53-60.

69 Relief dedicated by Peisis, see van Straten, o.c. (n. 47), no. R74; Ergon 1958, p. 36. A large, painted, terracotta kouros previously suggested to represent Apollon (Ergon 1961, p. 33 and 29, fig. 29) has recently been identified as a kore figure; see V. Mitsopoulos-Leon, "Tonstatuetten im

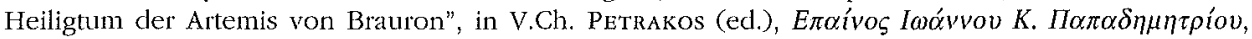

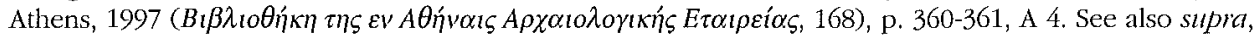
n. 53, for the epigraphical evidence for Apollon at Brauron.

70 Hekate: PAAH 1945-48, p. 88-89, fig. 6; BCH 73 (1949), p. 527, fig. 10; SARIAN, l.c. (n. 67), p. 998, no. 114 ( 3 rd century BC). Kybele: the statue is already mentioned by Ross, l.c. (n. 2), p. 255; Ergon 1960, p. 28-29, fig. 39; BCH 85 (1961), p. 639 and 643, fig. 10.

71 See $P A A H 1945-48$, p. 89, fig. 7; Ergon 1962, p. 32 and fig. 43; E. Vikelas \& W. Fuchs, "Zum Rundaltar mit archaistischen Götterzug für Dionysos in Brauron", Boreas 8 (1985), p. 41-48, dating the altar to $c$. 420-410. KaHIL ([1984], l.c. [n. 6], no. 1185) suggests that the seated female figure is Artemis and dates the altar to $c .500-450$ BC. A coverlet mentioned in the inventories of offerings, which incidentally is the only object listed as being new, is said to depict Dionysos and a woman pouring libations, see $I G \mathrm{II}^{2}, 1514,30-32 ; 1515,22-24 ; 1516,10-11$; LINDERs, o.c. (n. 8), p. 13. On the possibility of the performance of rural Dionysia at Brauron, mentioned in a scholion to Ar., PaC., 874 b (Holwerda), see Deubner, o.c. (n. 20), p. 138 and 208, n. 6; Whitehead, o.c. (n. 2), p. 212-213; Brulé, o.c. (n. 9), p. 310-313; Peppas-Delmousou, l.c. (n. 7), p. 327.

72 For the terracotta reliefs, pinakes and figurines, see LIMC, Indices, vol. 1, s. $v$. Brauron; KAHIL, l.c. (n. 49), p. 233-234 and figs. 15.3 and 15.4; Mitsopoulos-Leon, l.c. (n. 69), p. 357-378. A relief plaque with two enthroned females has been suggested to represent Artemis and Iphigeneia (Ead., l.c. [n. 69], p. 368 and fig. 5). The bulk of the Brauron figurines have no attributes or characteristics but many represent distinct types of Artemis, such as the goddess seated on a bull (Tauropolos), playing the kithara, carrying a deer, lion or other quadruped, holding a torch and accompanied by a dog, shooting her bow, holding a small girl or being enthroned holding a flower. Some of the terracottas show Artemis as a kourotrophos, an aspect of the goddess particularly strong at Brauron (see KaHIL, l.c. [n. 22], p. 802; Ead., l.c. [n. 68], p. 53-60; Ead. [1984], l.c. [n. 6], p. 676, no. 721; Ead., l.c. [n. 49], p. 233, fig. 15.3). Such a role is not characteristic of Iphigeneia (see KEarNs, o.c. [n. 31], p. 27). 
documented also at other sanctuaries and she was even said to have had a grave at Megara. This information, however, is only reported in late sources. ${ }^{73}$ At Brauron, some have seen Iphigeneia as an older, perhaps even a prehistoric, goddess gradually taken over by Artemis. ${ }^{74}$ Others have recognized in Iphigeneia an aspect of the character of Artemis or simply an epithet of the goddess, which in time developed into a separate divinity. ${ }^{75}$ Whatever her original relation to Artemis, this earlier Iphigeneia has also been viewed as being overshadowed or supplanted by the epic Iphigeneia, daughter of Agamemnon. ${ }^{76}$

In any case, the existence of a cult of Iphigeneia at Brauron rests to a large extent on the archaeological evidence, in particular, the structures considered as being her tomb or beroon, but also on the interpretation of the northern section of the stoa and the adyton of the temple as connected with her cult. These archaeological remains have then been used to back up the validity of literary evidence, Euripides in particular. It has even been claimed that Iphigeneia's role at Brauron may have been a literary invention by Euripides, had it not been confirmed by the excavations. ${ }^{77}$ This is clearly a circular argument, since it is on the basis of Euripides that these structures were identified as belonging to Iphigeneia in the first place. Since Iphigeneia's presence at Brauron, as known from the literary sources, seems to be supported neither by the epigraphical nor by the iconographical evidence, it is of interest to take a closer look at the archaeological material interpreted as connected with her cult.

\section{The tomb and beroon of Iphigeneia}

The area chiefly connected with Iphigeneia at Brauron and identified as her tomb and beroon lies to the south-east of the temple of Artemis at the foot of the acropolis which makes up the southern extension of the sanctuary (Fig. 1, nos. 6-7, and Figs. 2-3). ${ }^{78}$ This part of the sanctuary can be divided into three entities: (1) a cave or cleft-

73 According to Pausanias, there was a sanctuary of the Iphigeneian Artemis at Hermione (II, 35,2 ), an ancient statue of Iphigeneia in the temple of Artemis at Aigeira (VII, 26, 5) and a burial tumulus belonging to Iphigeneia at Megara (I, 43, 1); see also Hollinshead, l.c. (n. 9), p. 428; Brulé, o.c. (n. 9), p. 186-200, esp. 199, fig. 27 and table 5; DowDEN, o.c. (n. 9), p. 9-24, esp. 19-20. Since the name Iphigeneia occurs elsewhere than in Attica, she cannot have been a purely local deity; see KeARns, o.c. (n. 31), p. 32.

74 L.R. FARNELL, Greek bero cults and ideas of immortality, Oxford, 1921, p. 18 and 55-58; Papadimitriou, l.c. (n. 4), p. 113; Kondis, l.c. (n. 3), p. 160-162; Sale, l.c. (n. 14), p. 274́; Henrichs, l.c. (n. 17), p. 202; Kahil, l.c. (n. 49), p. 233; Llor'D-Jones, l.c. (n. 17), p. 95; JouAN, o.c. (n. 9), p. 10-11; Hollinshead, l.c. (n. 9), p. 425-426; Dowden, o.c. (n. 9), p. 45-46; Mylonopoulos \& Bubenheimer, l.c. (n. 50), p. 16. An I-pe-de-me-ja is known from the Linear B texts; see M. Rocchi, "Osservazioni a proposito de I-pe-me-de-ja", in E. DE Miro, L. Godar'r \& A. SACCONi (eds.), Atti e memorie del secondo congresso internazionale di micenologie, Roma-Napoli, 14-20 ottobre 1991, Rome, 1996 (Incumabula graeca, 98:2), p. 861-867; cf. AreTz, o.c. (n. 9), p. 33-36, esp. 35. On her name referring to "birth", see below, n. 183.

75 Sourvinou, l.c. (n. 17), p. 340; M. Platwauer (ed.), Euripides, Iphigeneia in Tauris: With introduction and commentary, Oxford, 1938, p. Ix; KEARns, o.c. (n. 31), p. 32; Bodson, l.c. (n. 20), p. 306.

76 KaHIL, l.c. (n. 49), p. 233; Jouan, o.c. (n. 9), p. 10-11; Hollinshead, l.c. (n. 9), p. 426; Dowden, o.c. (n. 9), p. 5 and 47; Mýonopoulos \& Bubenheimer, l.c. (n. 50), p. 16; Kearns, o.c. (n. 31), p. 27.

77 Kahil, l.c. (n. 27), p. 719; see also OsBorne, o.c. (n. 2), p. 164.

78 PAAH 1956, p. 75-77; PAAH 1957, p. 42-45, fig. 1; Ergon 1956, p. 25-28; Ergon 1957, p. 20-22; see also $P A A H 1949$, p. $79-83, P A A H 1950$, p. $175-177$, and $P A A H 1955$, p. $118-119$. 
like area housing a series of rooms, (2) a building at the north-western entrance of the cave, the "Small Temple", and (3) a building outside the cave to the south-east, the "Sacred House". The designations of the three parts vary considerably among scholars, as is clear from Table 1, but to facilitate the discussion of these remains, the designations proposed by Papadimitriou have been adopted here, though I do not necessarily agree with the functions they imply (see further below). ${ }^{79}$

Table 1. Suggested designations of structures connected with Iphigeneia to the south-east of the temple of Artemis.

\begin{tabular}{|c|c|c|c|}
\hline Scholar & Cave & "Small Temple" & "Sacred House" \\
\hline $\begin{array}{l}\text { Papadimitriou, } P A A H 1955, \\
\text { p. } 119 ; P A A H 1956, \text { p. } 76\end{array}$ & $\begin{array}{c}\text { Tomb-kenerion of the } \\
\text { heroine Iphigeneia; } \\
\text { kenerion of Iphigeneia }\end{array}$ & Mikron bieron & Hera oikia \\
\hline Papadimitriou (n. 4), p. 114 & - & Tomb of Iphigeneia & - \\
\hline $\begin{array}{l}\text { Kahil (1963), (n. 6), p. 5-6 with } \\
\text { n. } 5\end{array}$ & - & Heroon of Iphigeneia & - \\
\hline Kondis (n. 3), p. 166 & Tomb of Ipbigeneia & Mikron bieron & Oikos \\
\hline Boersma (n. 135), p. 38, no. 132 & - & Tomb of Iphigeneia & - \\
\hline Hollinshead (n. 9), p. 433, fig. 5 & - & Mikjon bieron & - \\
\hline Themelis (n. 7), fig. 2 & \multicolumn{3}{|c|}{ So-called beroon of Iphigeneia and Sacred House } \\
\hline $\begin{array}{l}\text { Brulé (n. 9), p. } 239 \text { and } 243 \text {, } \\
\text { fig. } 28\end{array}$ & Hieron & $\begin{array}{l}\text { Heroon or cenotaph } \\
\text { of Iphigeneia }\end{array}$ & Sacred House \\
\hline Travlos (n. 3), p. 55 & - & Tomb of Iphigeneia & - \\
\hline Antoniou (n. 7), p. 146-147 & $\begin{array}{c}\text { Tomb or cenotaph of } \\
\text { Iphigeneia }\end{array}$ & Hieron of Iphigeneia & $\begin{array}{l}\text { Sacred House } \\
(\text { olkia })\end{array}$ \\
\hline Eustratiou (n. 87), p. 80 & $\begin{array}{l}\text { Tomb of Iphigeneia, } \\
\text { the kenerion }\end{array}$ & Heroon of Iphigeneia & - \\
\hline $\begin{array}{l}\text { Mylonopoulos \& } \\
\text { Bubenheimer (n. } 50 \text { ), p. } 9 \text {, } \\
\text { fig. } 1\end{array}$ & $\begin{array}{c}\text { Structures within cave } \\
\text { area }\end{array}$ & $\begin{array}{l}\text { So-called Mikron } \\
\text { bieron or beroon of } \\
\text { Iphigeneia }\end{array}$ & $\begin{array}{l}\text { So-called Hiera } \\
\text { oikia }\end{array}$ \\
\hline
\end{tabular}

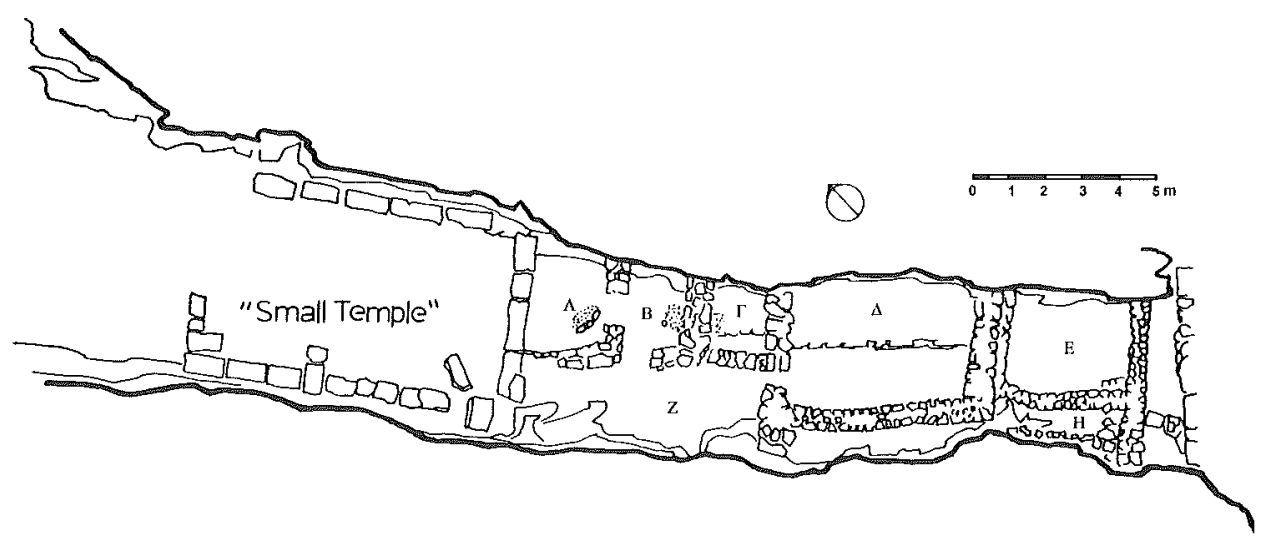

Fig. 2. The cave area to the south-east of the temple of Artemis. From PAAH 1957, p. 43, fig. 1.

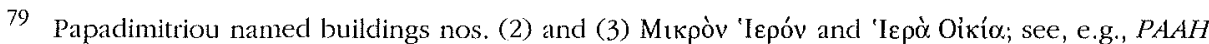
1955 , p. 119. 


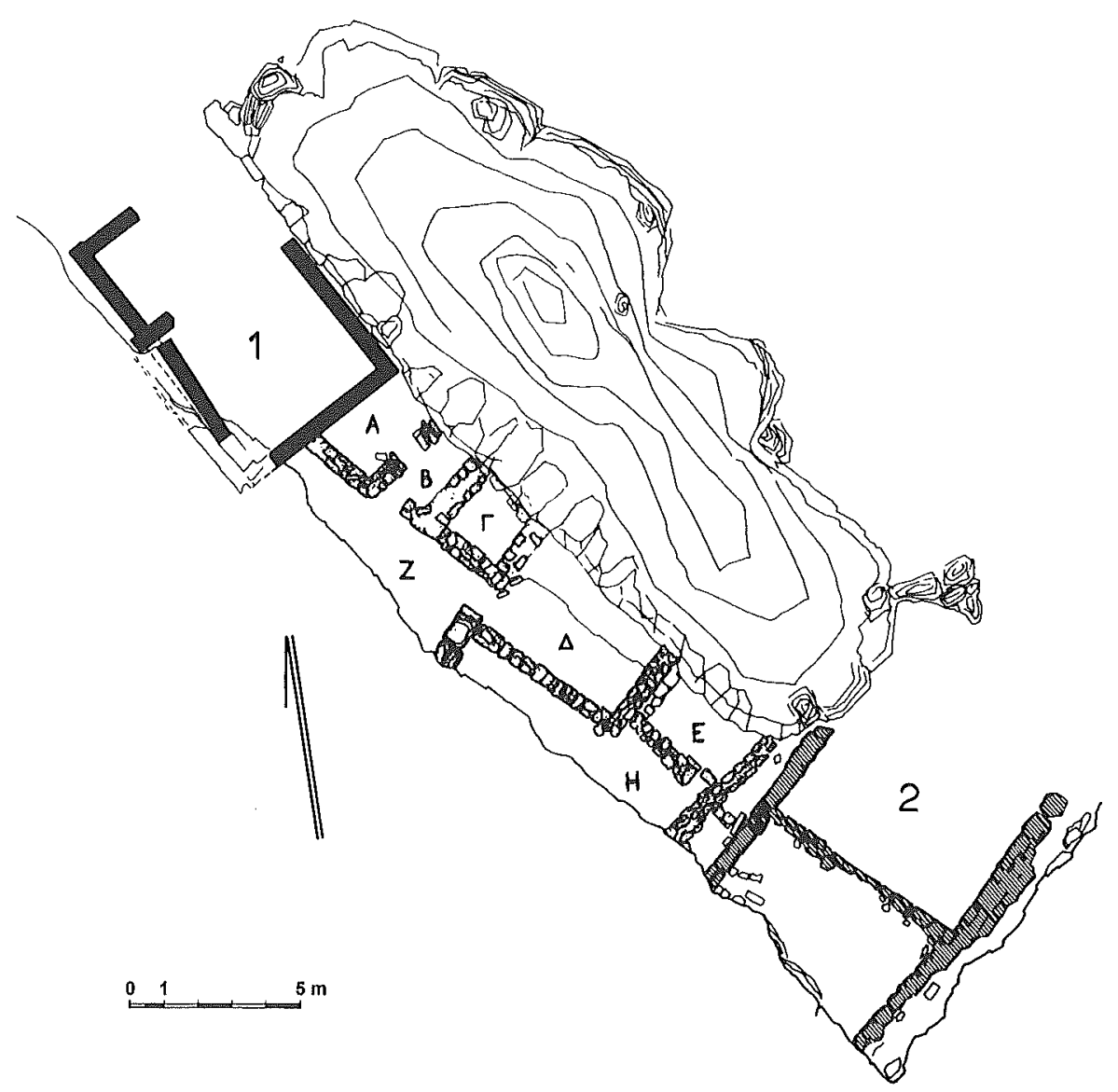

Fig. 3. The cave area to the south-east of the temple of Artemis.

From Themelis, 1976, o.c. (n. 49), fig. 11: 1. "Small Temple"; 2. "Sacred House".

\section{The cave}

The cave itself, which in antiquity was perhaps more like a cleft, was originally $c$. $25 \mathrm{~m}$ long and c. $5 \mathrm{~m}$ wide. It was entered from the north-west, i.e. from the direction of the temple of Artemis. Initially, there seem to have been four rooms within the cave, connected by a corridor $(\mathrm{Z}-\mathrm{H})$ to the south-west along the edge of the cliff (Figs. 2-3). The constructions were of a simple kind with walls built of small stones and clay. ${ }^{80}$ The layout of the two rooms which were constructed first, $A$ and $\Gamma$, is not entirely clear. ${ }^{81}$ Room $A$ was entered from the south-west and must originally have continued further to the north-west, later to be covered by the eastern part of the "Small Temple". The length of room A was at least $4 \mathrm{~m}$ and it was divided by a large opening into two sections. The entire floor of this room was found covered by ashy

$80 \quad P A A H 1956$, p. 75.

81 See especially $P A A H$ 1957, p. 42-44; Ergon 1957, p. 21. 
soil, which continued to the north-west, in under the "Small Temple". ${ }^{2}$ Spread all over the room were a number of small pits, filled with ash and black soil and covered by sea-pebbles. ${ }^{83}$ From these pits were recovered a quantity of sherds of goodquality, 6th- and 5th-century pottery, parts of marble vessels, many terracotta figurines and more than ten simple, bronze mirrors.

Facing room A to the south-east lay room $\Gamma$, which was $c .3 \mathrm{~m}$ long and $c .2 \mathrm{~m}$ wide and was entered from the north-west. In the centre of this room, there seems to have been a hearth or pyre. At a later stage, the layout of this part of the cave was transformed. New walls were built and room A seems to have been divided into two smaller sections, $\mathrm{A}$ and $\mathrm{B}$, by the construction of two short, transversal walls. Room $\Gamma$ was separated from room $A$ by a transversal wall, which was constructed on top of the hearth or pyre in room $\Gamma$ (see Fig. 2). The construction of this wall created a room of smaller size, $2.05 \times 1.98 \mathrm{~m}$, and it is not clear from which direction this room was accessible. ${ }^{84}$

Further to the south-east lay two more rooms, $\Delta, c .5 \times 3.5 \mathrm{~m}$, and E, $c .3 \times 3 \mathrm{~m}$, which seem to have had a higher floor level than the rooms to the north-west. ${ }^{85}$ Also here were found spots of ash and ashy soil with a number of sherds and figurines. In the southern part of room $\Delta$ was discovered a pit surrounded by stones and filled with dark soil (not indicated on any plans). In the corridor to the south-west of room $\Delta$ was found a channel full of black soil and 6th-5th-century pottery, leading up to a small pit, filled with sea-sand and gravel. ${ }^{86}$ This channel was probably connected also to the pit within room $\Delta$, since the south-western wall of this room had an opening close to this pit, presumably serving as an outlet. The easternmost room $\mathrm{E}$, finally, lay at the end of the corridor and the cave, but nothing is known of the interior arrangements. This room seems to have been accessible only from the south-west by the corridor $\mathrm{H}$ and there was apparently no communication between this room and the "Sacred House" situated further to the south-east (Fig. 3).

The earliest pottery reported from within the cave is said to date from the 8th century $\mathrm{BC}$ and these finds are probably to be associated with the rooms $\mathrm{A}, \mathrm{E}$ and $\Delta .{ }^{87}$ No material found is reported to be later than the 5 th century BC. The excavator suggested that the cave must have gone out of use sometime during this century when its roof collapsed and covered the structures within ${ }^{88}$ No attempt seems to have been made to clear the area in antiquity.

Papadimitriou suggested that the cave had two functions corresponding to Euripides' statements, namely being both the beroon or burial place of Iphigeneia and

82 PAAH, 1957, p. 42.

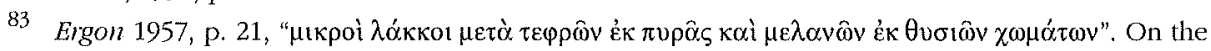
plan in PAAH 1957, p. 43, fig. 1 (= my Fig. 2), a spot of ash bordered by stones on its southern side is indicated in room $A$.

84 Ergon 1957, p. 20.

85 PAAH 1957, p. 44.

86 Engon 1957, p. 21.

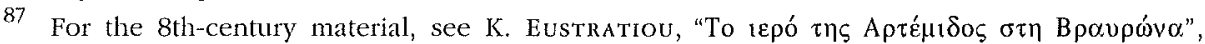

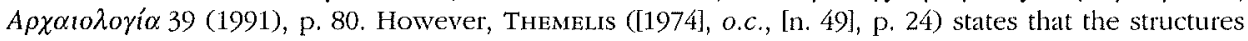
within the cave are no earlier than $c .700 \mathrm{BC}$. The earliest pottery published from this area by KaHIL ([1963], l.c. [n. 6], p. 6, no. 1) is a fragment of a Protoattic amphora dated to around $700 \mathrm{BC}$.

88 PAAH 1955, p. 119; PAAH 1956, p. 75-76; PAAH 1957, p. 45; PAPADIMITRIOU, l.c. (n. 4), p. 115; cf. Themelis (1974), o.c., (n. 49), p. 26; Eustratrou, l.c. (n. 87), p. 80. 
a storage space for offerings made to her. ${ }^{89}$ The excavator supported his assertation that the cave area was the site of Iphigeneia's tomb with the fact that four inhumations were actually found in this area. ${ }^{90} \mathrm{He}$ suggested that these were the graves of later priestesses of Artemis-Iphigeneia, who had been buried here just as their predecessor in office, Iphigeneia, was. This interpretation is unlikely for several reasons. First of all, burial within a sacred area in the historical period, even of religious office-holders, seems highly implausible. ${ }^{91}$ Secondly, as far as it is possible to date these tombs, it seems clear that they belong to the Roman period. While two of these burials yielded no finds at all, a coin dated to AD 104 was found in the third tomb and the fourth burial was covered by large roof-tiles, a kind of tomb construction common in later periods. ${ }^{92}$ Thus, one burial was definitely Roman, the tile grave probably so and the remaining two are also plausibly assigned to the same period, presumably the 2nd century $\mathrm{AD}$, when the site had been long abandoned as a functioning sanctuary. The graves are therefore best taken to be of no relevance to the cult of Iphigeneia.

The absence of any prehistoric remains within the cave area is also to be noted. ${ }^{93}$ There are no traces of Bronze Age burials or habitation, which in the historical period may have been identified as the "tomb of Iphigeneia" or inspired the idea of her being buried there and triggered a cult directed to her at this location. ${ }^{94}$ Any argument for

89 PAAH 1956, p. 76.

90 PAAH 1955, p. 118-119; PAAH 1956, p. 76-77; PAAH 1957, p. 44-45.

91 On the relation sanctuaries and death, see R. PARKER, Miasma: Pollution and purification in early Greek religion, Oxford, 1983 , p. 32-48, esp. 33-34. There is no information as to whether any osteological examination of the bones has been undertaken in order to decide the sex of the deceased persons.

92 The dated grave, having walls of poros stones, was located just outside the south-western corner of the "Sacred House" close to its wall. Next to the outstretched skeleton was found a small glass phiale with a long neck, while two bronze coins, both worn, had been placed in the mouth of the dead person; see PAAH 1955, p. 118-119, pl. 38 a; Ergon 1956, p. 28. Of the two graves lacking finds, one was found behind the back wall of the "Small Temple" (PAAH 1955, p. 119; Ergon 1956, p. 28) and the other one in the south-western section of the "Sacred House", between this building and the rock of the acropolis ( $P A A H$ 1956, p. 76-77). The tile grave was also located in the area between the "Sacred House" and the rock of the acropolis; see PAAH 1956, p. 76-77, pl. $19 \mathrm{~g}$.

93 The sanctuary of Brauron has yielded traces of human activity from as early as the Neolithic period. On the crescent-shaped hill delimiting the sanctuary to the south, substantial MH and LH remains have been found, in the form both of a settlement with a defence wall and of burials, and further LH burials are known from the region; see $P A A H 1950$, p. 187; PAAH 1955, p. 119-120; PAAH 1956, p. 77-89; Ergon 1956, p. 28-31. A few MH and LH sherds have come to light in the excavation of the sanctuary; see Ergon 1960, p. 23. Two Mycenaean, female, terracotta figurines are reported from later cult deposits within the site, but there is no information as to their exact find-spots (E. FreNCH, "The development of Mycenaean terracotta figurines", ABSA 66 [1971], p. 179; French, personal communication). These prehistoric finds probably stem from the acropolis and there is no trace of the site being used in the BA period either as a settlement or for religious purposes.

94 Though the earliest hero-cults do not seem to be located in connection with Bronze Age tombs, there are in several cases other prehistoric remains nearby which may have inspired the cult or been decisive for its location. The Menelaion at Sparta, for example, was located near the ruins of a Mycenaean mansion (see H. CATLing, "Excavations at the Menelaion", $A R$ 1976-77, p. 2542), while the Agamemnoneion at Mycenae is situated next to a Mycenaean bridge or dam across the Chaos ravine (see J.M. Соoк, "Mycenae, 1939-1952. Part III. The Agamemnoneion", ABSA 48 [1953], p. 30-66; J. KNauss, "Agamemnóneion phréar': Der Stausee der Mykener", AntW 28 [1997], p. 381-395). See also, see C.M. ANTronaccio, An archaeology of ancestors: Tomb cult and bero cult in 
Iphigeneia being worshipped at this site as the continuation of a cult of a Bronze Age, cave-dwelling goddess is based solely on inference and has no support in the archaeological evidence. ${ }^{95}$

In all, there is no part of the cave and its structures which sticks out as a suitable candidate for the tomb of Iphigeneia, corroborating Euripides' statement that she was to be buried at Brauron after serving there as the first priestess of Artemis. ${ }^{96}$

\section{The finds}

Considering the richness and variety of the material found in the cave area, the second function proposed by Papadimitriou, as a space for storing offerings, seems more plausible. In the cave itself, as well as in the open space in front of it to the east, were recovered fragments of inventory inscriptions and it is likely that these were displayed close to the locations where the offerings were kept. ${ }^{97}$ If this was the case, the cave may also have housed textile offerings.

In order to evaluate the current interpretation of this area as connected with Iphigeneia, it is of interest to take a closer look at the finds recovered here and compare them with the finds made elsewhere in the sanctuary (see Table 2). ${ }^{98}$ Within the cave itself was found pottery dating from the 8 th to the 5 th centuries BC. ${ }^{99}$ It is of high quality and included good pieces of Protoattic, black-figure, red-figure and white ground, as well as a considerable number of krateriskoi of the kind usually connected with the arkteia ${ }^{100}$ Many of the pottery shapes are related to eating and drinking, such as amphorai, kraters, cups and plates, but there are also several examples of "female" vessels, pyxides and epinetra, for example. ${ }^{101}$ A substantial number of terracotta figurines was also found. ${ }^{102}$ No information as to their appearance is given, but it is said that the date seems to be mainly the 6th and 5 th

Early Greece, Lanham, 1995 (Greek studies: Interdisciplinary approacbes), p. 146-152, $155-166$ and 245-252.

95 A prehistoric origin of Iphigeneia was suggested by Papadimitriou, l.c. (n. 4), p. 113; $c f$. BODSON, l.c. (n. 20), p. 306.

96 The argument that Iphigeneia may have lacked a tomb, since she was originally a goddess, is not of importance in this context, considering the fact that Euripides states that she was to die and be buried. Furthermore, the distinctions between gods and heroes seem to have been more blurred in antiquity than most modern scholars have been willing to admit, in particular, as regards the sacrificial practices; see Екrотн, o.c. (n. 1), passim.

97 Linders, o.c. (n. 8), p. 72; Hollinshead, l.c. (n. 9), p. 434. Mŕlonopoulos \& Bubenheimer (l.c. [n. 50], p. 21) suggest that bronzes were stored in the "Small Temple". On the problems concerning the chronology of these inscriptions, see infra, n. 107.

98 The difficulties of establishing a divinity's identity from the finds and votive material alone have been pointed out by a number of scholars; see, for example, B. Alroth, "Visiting gods - who and why?", in 'T. Linders \& G. Nordquist (eds.), Gifts to the gods: Proceedings of the Uppsala symposium 1985, Uppsala, 1987 (Boreas, 15), p. 9-19; D.B. Thonpson, Troy: The terracotta figurines of the Hellenistic period, Princeton, 1963 (Troy supplementary monograph, 3), p. 56; Deovor, o.c. (n. 1), p. 49. Still, a discussion of the finds from a certain site in a wider context can surely supply important insights as to the use and function of a structure or a building.

99 8th-century material from this area is reported only by Eustratiou, l.c. (n. 87), p. 80.

${ }^{100}$ On the krateriskoi, see Kanil (1965), l.c. (n. 6), p. 20-32, esp. 20.

101 For the pottery, see KaHIL (1963), l.c. (n. 6), p. 5-29; PAAH 1949, p. 87-90; PAAH 1956, p. 75-76;

PAAH 1957, p. 44-45; Ergon 1955, p. 33; Eigon 1956, p. 27; Eigon 1957, p. 21.

102 PAAH 1956, p. 75; PAAH 1957, p. 45; Ergon 1957, p. 21. 
centuries. Fragments of marble vessels were also recovered, ${ }^{103}$ as well as bronze mirrors, ${ }^{104}$ bronze rings, gold ornaments, gems and other pieces of jewellery ${ }^{105}$ and fragments of reliefs and sculptures. ${ }^{106}$ The site is also said to have yielded inscriptions, some of which were catalogues of votive offerings and identical with those originating from the sanctuary of Artemis Brauronia at Athens. ${ }^{107}$

The material from the cave area at Brauron can no doubt be considered as being suitable gifts for a heroine who, according to Euripides, was to receive the clothes of women who died in childbirth and therefore had a particular interest in the female sphere. On the other hand, the finds are just as appropriate as dedications to Artemis and do, in fact, correspond closely with the offerings mentioned in the inventories. Furthermore, the find assemblage from the cave area shows many similarities to the material recovered at two other locations within the sanctuary, both usually viewed as connected with the cult of Artemis: the spring to the north-west of the temple and a building to the east of the late-5th-century stoa (see Fig. 1, nos. 2 and 9).

At the spring, the material dates back to before $700 \mathrm{BC}$, but the bulk dates to the 7 th, 6th and early 5 th centuries $B C{ }^{108}$ The excavator suggested that the area west of the temple at the spring must have been the main focus of the sanctuary and the holiest of holies, so to speak, particularly in the period prior to the sacking by the Persians. ${ }^{109}$ The importance of this location would account for the abundance and quality of the material recovered, but, in general, the composition of the spring assemblage is in many aspects similar to that of the cave area (see Table 2). Abundant pottery was found, including krateriskoi, as well as terracotta figurines and painted terracotta relief plaques. ${ }^{110}$ Bronze mirrors and other bronze objects were among the finds, as well as pieces of jewellery, rings, seal stones and fragments of gold. ${ }^{111}$ Glass

103 PAAH 1956, p. 76; Ergon 1957, p. 21.

104 PAAH 1956, p. 75; PAAH 1956, p. 76; PAAH 1957, p. 45; Ergon 1957, p. 21.

105 PAAH 1957, p. 45; Papadimitriou, l.c. (n. 4), p. 115.

106 PAAH 1957, p. 45; Ergon 1957, p. 21.

107 PAAH 1956, p. 75-76; the inscriptions found are said to be identical with $I G \mathrm{II}^{2}, 1517,1524$, 1529; cf. PAAH 1957, p. 45; Ergon 1956, p. 27-28; Ergon 1957, p. 21-22. This would mean that these Brauronian texts also date from the 4 th century $\mathrm{BC}$. This is problematic, since Papadimitriou states that no material later than the 5 th century was recovered from the cave area $(P A A H 1955$, p. 77). However, inscriptions or catalogues were also recovered in front of the cave, an area where votives and stelai were displayed and which was not affected by the collapse of the cave in the 5th century. Is it possible that some of the 4th-century inscriptions said to derive from the cave may have come from the area in front of it? Perhaps broken inscriptions may have been dumped on top of the rubble where the cave used to be.

108 Ergon 1961, p. 30-34; PAAH 1959, p. 19; Ergon 1959, p. 16; cf. Ergon 1962, p. 27-28. Parts of the material must have been intentionally deposited, since it is said to have been stratigraphically recovered. However, the top levels may derive from the destruction and plundering of the first temple by the Persians and the cleaning up that took place afterwards in the mid-5th century BC. Along the northern terrace wall supporting the platform of the temple, a layer of ash mixed with small fragments of pottery and other finds was found under the 4th-century-BC, stele bases (PAAH 1950, p. 177). Papadimitriou suggested that material from an older altar area had been used to level the ground. However, it is possible that this ashy soil may be the destruction debris of the first temple, razed by the Persians.

109 Ergon 1961, p. 31-32.

110 PAAH 1959, p. 19; Ergon 1961, p. $32-33$ and figs. 33 and 36-37; KAHIL (1963), l.c. (n. 6), nos. 12, 22, 28, 29, 36, 44, 53 and 58; Ead. (1965), l.c. (n. 6), p. 20.

111 PAAH 1959, p. 19; Ergon 1961, p. 32-33 and figs. 28 and 30-32. 
objects were recovered and, owing to the wet conditions in the area, wooden boxes and vases and bone implements, such as a flute. ${ }^{112}$ Parts of sculptures, such as heads of arktoi, and reliefs were also found, together with inscriptions, many of which seem to have been catalogues of votive offerings. ${ }^{113}$ The deposit may also have yielded marble vessels. ${ }^{114}$

Table 2

Comparison of the find assemblages from the cave area, the spring north-west of the temple and the building to the east of the 5th-century stoa. It should be noted that heads of arkto $i$ and the marble reliefs found at the spring may originally have been placed on top of the terrace to the north of the temple and arrived in the spring area as a result of the plundering and destruction of the temple rather than being intentionally deposited there (see further, n. 108).

\begin{tabular}{|l|c|c|c|}
\hline \multicolumn{1}{|c|}{ Find category } & Cave area & Spring & Eastern building \\
\hline 8th-century pottery & $\times$ & $\times$ & \\
7th-century pottery & $\times$ & $\times$ & $\times$ \\
Gtb-century pottery & $\times$ & $\times$ & $\times$ \\
5th-century pottery & $\times$ & $\times$ & $\times ?$ \\
Krateriskoi & $\times$ & $\times$ & $\times$ \\
Terracotta figurines & $\times$ & $\times$ & \\
Terracotta plaques & $\times$ & $\times ?$ & $\times ?$ \\
Marble vessels & & $\times$ & \\
Heads of arktoi & $\times$ & $\times$ & \\
Marble reliefs & $\times$ & $\times$ & \\
Fragm. of sculpture & $\times$ & $\times$ & \\
Bronze mirrors & $\times$ & $\times$ & \\
Bronze objects & $\times$ & $\times$ & $\times$ \\
Jewellery & $\times$ & $\times$ & $\times$ \\
Seal stones & & $\times$ & $\times$ \\
Gold & & $\times$ & $\times$ \\
Wooden objects & $\times$ & $\times$ & \\
Bone objects & & & \\
Glass objects & & $\times$ & \\
Inscriptions & & $\times$ & \\
\hline
\end{tabular}

The second area of interest lies east of the 5th-century stoa, where the remains of an earlier building were discovered, probably dating to the Archaic period (Fig. 1, no. 9). ${ }^{115}$ Pottery of 7 th- and 6th-century date, some of which was of Corinthian origin,

112 Ergon 1961, p. 32-33, and figs. 26-26 and 34-35. Certain material categories, such as wood and bone, probably had a better chance of survival in the moist layers at the spring than elsewhere in the sanctuary.

113 PAAH 1959, p. 19 and pl, 12 b-d and 13 a; Ergon 1959, p. 16-17, figs. 15-17. These objects seem mainly to have been recovered in the upper levels of the area and may belong to the post-Persian period (see above, n. 108).

114 Cf. Ergon 1962, p. 32 and fig. 41.

115 Ergon 1960 , p. $21-22$; Ergon 1962 , p. $28-32$ and fig. 36 . For the layout and function of this building, see below, p. 107-108. 
and terracotta figurines were recovered from the building, but also jewellery, decorated gold objects, seal stones and glass vessels (see Table 2). ${ }^{116}$ No marble sculpture or reliefs are reported, but two terracotta, female heads with gildect hair were found, as well as the upper part of the body of a large, wooden, female statuette. ${ }^{117}$ Fragments of inscriptions were recovered and marble vessels may also have been found in connection with this building. ${ }^{118}$

In all, there is nothing in the votive material recovered from the cave that indicates that this location housed the worship of a particular divinity distinct from Artemis, the principal recipient of worship at the sanctuary. As stated above, there seems to be no mention of Iphigeneia on any of the artefacts recovered from the cave and the material cannot be said to offer any independent support for Iphigeneia being worshipped here, although the area may certainly have been used for the storage of dedications. ${ }^{119}$ The similarity between the finds from the cave and the finds from the spring area and the eastern building rather points in the direction of all three areas being connected with the same divinity.

\section{The function of the cave, the "Sacred House" and the "Small Temple"}

Thus, there seems to be no trace of any burial within the cave which may have been identified as Iphigeneia's tomb in antiquity and the find assemblage from this area offers no independent support for her cult being housed there. The conclusion that this part of the sanctuary was reserved for Iphigeneia seems rather to be the result of the search for suitable evidence to match Euripides' statements in the $I T$, in combination with the general assumptions on what characterizes a hero-shrine, for example, a location within a cave. If, on the other hand, the cave area was used for storing offerings, which seems likely, it may just as well have been the dedications to Artemis.

However, a storage function has to be correlated to the rest of the archaeological evidence from this area, in particular, the ash and the ash-filled pits. The storing of dedications, especially of textiles, is hardly compatible with the use of fire within rooms of fairly limited sizes, such as those in the cave.

The features discovered within the cave, such as the ash-filled pits and the drain, suggested to be an offering trench, are installations which have often been considered as typical of hero-cults and chthonian cults in general. ${ }^{120}$ As stated above, the understanding of what is meant by a chthonian cult and how it is to be

116 Ergon 1961, p. 21-22; Ergon 1962, p. 31-32 and fig. 37; KAHIL (1965), l.c. (n. 6), p. 20. Krateriskoi may also have been found in this part of the sanctuary; see Ead. (1965), l.c. (n. 6), p. 20.

117 Ergon 1962, p. 30-31, figs. 38-39.

118 Eigon 1961, p. 21; Ergon 1962, p. 32.

119 Some of the pottery bearing dedications to Artemis may have come from the cave area; see PAAH 1949, p. 90. Mrlonopoulos \& Bubenheimer (1.c. [n. 50], p. 16) claim that this area yielded material typical of a chthonian divinity, such as aryballoi and lekythoi. As far as it is possible to tell from the preliminary reports, no aryballoi have been recovered from the cave, only from the building to the east of the stoa (Ergon 1961, p. 21) and from deep levels to the east of the great stoa, probably brought there by erosion (Ergon 1961, p. 28-29).

120 Mylonopoulos \& Bubenheimer, l.c. (n. 50), p. 16; cf. silpia, n. 119. Papadimitriou (l.c. [n. 4], p. 116) considered caves as particularly connected with hero-cults (see further supra, n. 42). C/. Kondis, l.c. (n. 3), p. 166, arguing that the "Small Temple" having an entrance facing west confirms the chthonian character of the heroine worshipped there. 
recognized in the archaeological record are questions which have recently been under debate. ${ }^{121}$ It seems increasingly clear that our modern definitions of the installations usually considered as typically chthonian arrangements for cultic actions are based more on the armchair speculations of late antiquity than on the cultic reality of the Archaic and Classical periods. ${ }^{122}$ Alternative explanations of the use and function of the structures within the cave are therefore be considered, by analogy with the practical, cultic installations known from other Greek sanctuaries.

One of the principal activities in a Greek sanctuary was ritual dining and there is an increasing amount of evidence showing that dining facilities may have been among the earliest or even the earliest constructions at a sacred site, perhaps even earlier than the temple itself. ${ }^{123}$ Ash-filled pits are features commonly found where dining took place, the pits being used for cooking, either as in a proper kitchen or for simpler grilling or roasting in connection with the actual dining. ${ }^{124}$ In some cases, pits were filled with the debris from dining, as well as with cooking ware and votive gifts, and the deposit was sealed after the ceremony was concluded. ${ }^{125}$ The pits in rooms $A, \Gamma$ and $\Delta$ may have served as hearths (in particular, the pit bordered by stones in room $\Delta$ ) or constitute deposits left behind after ritual meals. The ash was particularly abundant in room $\mathrm{A}$ and was concentrated to a large spot bordered by stones, which may suggest a kitchen function.

The identification of the channel under the south-western wall in room $\Delta$ as an Opferrinne is also doubtful. Neither its construction nor its location fits what is known of offering trenches at other locations. ${ }^{126}$ On the other hand, drains are commonly found in dining-rooms as a means of facilitating the cleaning of the floor from dinner debris and this may have been the function of this channel as well. ${ }^{127}$ The ash, the ash-filled pits and the drain can therefore be taken as indications of the structures within the cave having been used for the preparation and consumption of meals, an activity concluding most sacrifices. However, archaeological evidence of this kind may also constitute the remains of a domestic use, i.e. by somebody living at this location. Admittedly, no cooking ware is reported from the Brauron cave, but the

121 See above, n. 47.

122 For references, see above, n. 48.

123 See B. Bergquist, "Feasting of worshippers or temple and sacrifice? The case of the Herakleion on Thasos", in HäGG, o.c. (n. 48), p. 57-72; Ead., "A particular, Western Greek cult practice? The significance of stele-crowned, sacrificial deposits", OAth 19 (1992), p. 41-47; C. Morgan, Isthmia VII: The Late Bronze Age settlement and Early Iron Age sanctuary, Princeton, 1999 , p. 374-375. Several "hearth temples" often considered as earlier, chthonian predecessors of later, proper, Olympian temples have now been re-interpreted as bestiatoria.

${ }^{124}$ On cooking pits, see, for example, the ones found near the Tholos in the Athenian Agora (H.A. Thompson, The Tholos of Athens and its predecessors, Athens, 1940 [Hesperia, suppl. 4], p. 2527 and figs. 13 and 42). For barbecue sites located directly on the ground, see B. Bergquist, "The archaeology of sacrifice: Minoan-Mycenaean versus Greek. A brief query into two sites with contrary evidence", in R. HäGG, N. Marinatos \& G.C. NordQUisT (eds.), Early Greek cult practice: Proceedings of the Fifth International Symposiam at the Swedisb Institute at Athens, 26-29 June, 1986, Stockholm, 1988 (ActaAtb-4ㅇ 38), p. 30-31, and Ead. (1992), l.c. (n. 123), p. 46.

125 On this particular practice, see Bergquist (1992), l.c. (n. 123), p. 41-47.

${ }^{126}$ On the use and appearance of offering trenches, see E. KISTLER, Die Opferrinne-'Zeremonie': Bankettenideologie am Grab, Orientalisierung und Formierming einer Adelsgesellschaft in Athen, Stuttgart, 1998, p. 20-50 and 177-180.

127 The sand and gravel in the pit in the corridor to the south-rvest of room $\Delta$ may perhaps be the result of repeated outpourings of water, draining away the soil. 
pottery assemblage included a number of shapes used for eating and drinking, such as amphorai, kraters, cups and plates. ${ }^{128}$ Dining in caves is known from other sanctuaries, the best-known case being the Theatre and North-eastern caves at the sanctuary of Poseidon at Isthmia, to which can be added examples from Thera and Crete. ${ }^{129}$ These caves housed both the actual dining-rooms, the kitchen and storage space for the utensils.

Thus, the cave at Brauron may have had two functions, on the one hand, to house various kinds of offerings made to Artemis and, on the other, to serve as a dining space or residential quarter. Bearing in mind the scarcity of the information available and the fact that the structures in the cave were severely damaged when the roof collapsed, it may tentatively be suggested that the cave may have had two phases of use and that both functions occurred in each phase.

In the first phase, the cave consisted of the rooms A, $\Gamma, \Delta$ and $E$ (Figs, 2-3). The finding of ash in small pits all over room $A$ and in more central pits in rooms $\Gamma$ and $\Delta$ may be taken as an indication of these areas being used for ritual dining or residential use. ${ }^{130}$ Room $\mathrm{E}$ seems to have no traces of ash and may have been reserved for the storing of offerings.

In the second phase, room $\mathrm{A}$ was divided by a transversal wall into two smaller sections, A and B, while $\Gamma$ was separated from A by an additional, transversal wall. The latter wall runs across the ash-spot in the centre of room $\Gamma$, indicating that the area may now have been given a different function, since the hearth could no longer be used. Perhaps this entire section ( $A, B$ and $\Gamma$ ) was now reserved for the storing of offerings, such as pottery, jewellery, bronzes, marble vessels and perishable goods, textiles, for example. Dining or living may still have continued in room $\Delta$, while room E was perhaps still also used for storage.

Of interest as regards the function of the cave is also the so-called "Sacred House", which occupied the space to the south-east of the cave. This rectangular building was partly cut out of the rock at the foot of the acropolis and had walls with

128 No findings of animal bones are mentioned either. Whether this is due to an absence of this kind of material or is simply a result of the preliminary state of publication cannot be decided at present.

129 For dining-rooms in caves, see O. BroneEr, Istbmia II: Topograpby and arcbitecture, Princeton, 1973, p. 33-46. For animal sacrifice and cult meals at the Psychro and Idean caves on Crete, see L.V. Watrous, The cave sanctuary of Zeus at Psycbro: A study of extra-urban sanctuaries in Minoan and Early Iron Age Crete, Liège \& Austin, 1996 (Aegaeum, 15), p. 54, 59 and 104; MorgAN, o.c. (n. 123), p. 319. See also the evidence from the Pilarou cave on Thera and the rock-cut chamber on the same site, probably used for seated meals and published by A. Kose, "Die Höhle Pilarou beim Felsheiligtum Christos", in W. HoEpFner (ed.), Das dorische Thera V: Stadtgeschicbte und Kultstätten am nördlichen Stadtrand, Berlin, 1997, P. 73-149, esp. 92-95; C. BECKER, "Knochenfunde aus der Höhle Pilarou - Reste von Tieropfern oder profane Schlacht- und Speiseabfälle?", in ibid., p. 151-183, esp. 165-170; N. Giallelis \& M. AntKowiak, "Die Kultstätte im Bezirk Christos", in ibid., p. 47-67, esp. 60-61.

130 Admittedly, the space for the diners is rather limited. However, in Early Archaic times, the participants may have been seated rather than reclining; see B. BERgquist, "Primary or secondary temple function: The case of Halieis", OAtb 18 (1990), p. 36, and $c f$. the rock-cut chamber at Thera, $2.82 \mathrm{~m}$ wide and $2.88 \mathrm{~m}$ deep, with a bench carved out of the rock on three sides, suggested to accommodate nine to eleven seated diners (see Giallelis \& ANTKOWIak, l.c. [n. 129], p. $48-49$ and 59-61). 
poros foundations (Fig. 1, no. 8, and Fig. 3, no. 2). ${ }^{131}$ The northern part of the "Sacred House" consisted of an apparently square room, c. $6.35 \mathrm{~m}$ wide, probably only accessible from the north and not communicating with the cave. The southern part of the building, the back wall of which was made up by the acropolis rock, measured c. $6 \times 2.5 \mathrm{~m}$ and has not been fully excavated. There is no sign of an entrance and perhaps this section was not a room but more of a buttress towards the rock. The "Sacred House" yielded material from the 6th and 5th centuries (pottery and terracotta figurines) and must have been contemporary in use with the cave. ${ }^{132}$

The function of the "Sacred House" is difficult to ascertain and Papadimitriou suggested that it may have been a house for the priestesses, hence the denomination Hiera oikia. ${ }^{133}$ However, if the cave to the north-west was gradually and to a greater extent used for the storing of votives, as was suggested above, this building may have taken over the dining functions of the cave. Since only pottery and figurines are said to have been found here, the difference in material recovered, as compared with the cave, may indicate a different function. The main argument for this building being used as a dining-room, however, is its proportions. The northern room of the "Sacred House", if reconstructed as being square in plan, has the dimensions that would fit eleven klinai of the size used in the dining-rooms in the stoa constructed to the north around $420 \mathrm{BC} .{ }^{134}$ If this interpretation of its function is correct, the meals for certain persons, perhaps important worshippers and religious office-holders, which previously took place within the cave, could at a later period have been transferred to the "Sacred House".

The construction of the "Small Temple" at the north-western entrance of the cave has been linked to the collapse of the roof of the cave, an event which has been dated to the mid-5th century BC (Fig. 1, no, 6, and Fig. 3, no. 1). ${ }^{135}$ This building must have been constructed after the structures in the cave went out of use, since the "Small Temple" partly covers the western part of room A and also spans the whole width of the cave, blocking any access into it. The inner dimensions of this building were $7.75 \times 4.45 \mathrm{~m}$ and the interior space was divided into a square back room, $4.65 \times 4.65 \mathrm{~m}$, and a rectangular front room, $4.65 \mathrm{~m}$ wide and $2.60 \mathrm{~m}$ deep. ${ }^{136}$ The foundations of the walls were built of poros blocks and the upper walls were apparently of mud-brick, since the interior space was found to be filled with soft, reddish soil. In the inner room was discovered a spot of black soil, $2.35 \times 1.25 \mathrm{~m}$, taken to be the remains of a hearth. Among the few finds reported from this structure is the head of a terracotta figurine of a young girl, dated to the first half of the 4 th century BC. ${ }^{137}$

131 PAAH 1950, p. 175-177; PAAH 1955, p. 118. On the possibility of a doorway in the southern part of the west wall, see $P A A H 1950$, p. 177.

132 PAAH 1950, p. 177; PAAH 1955, p. 118.

133 PAAH 1950, p. 175.

134 On the sizes of the stoa dining-rooms and its klinai, see Bouras, o.c. (n. 5), p. 71-78 and 9294.

135 Papadimtriou, l.c. (n. 4), p. 116; J.S. BoERsma (Athenian building policy from $561 / 0$ to $405 / 4$ $B C$, Groningen, 1970, p. 62 and 238, no. 132) suggests a construction date around $450 \mathrm{BC}$.

136 PAAH 1949, p. 83.

137 PAAH 1949, p. 90 and fig. 19, suggested to represent an arktos. 
This building has commonly been regarded as the bieron, beroon or tomb of Iphigeneia. ${ }^{138}$ It has also been suggested that it housed dedications, perhaps the bronzes mentioned in some of the inventories. ${ }^{139}$ The spot of ash found in the centre of this building raises obstacles to the latter function, though. If this ash was the remains of a hearth, the "Small Temple" may in fact have been used as a bestiatorion, having room for seven couches of the same size as those apparently used in the large stoa to the north. ${ }^{140}$ This small dining-room may have been used for a select group of diners and perhaps replaced one of the rooms within the cave. It is also possible that the "Sacred House" to the east was no longer in use in the late 5th century, perhaps having been damaged in the collapse of the cave, and the ritual meals suggested to have taken place there were now staged in the "Small Temple". ${ }^{41}$

The chronological relations between the structures in the cave and the "Small Temple" are not without complications, since the information in the preliminary reports is conflicting. The terminus post quem for the construction of the "Small Temple" has been the collapse of the cave, which has been set in the mid-5th century, since no objects recovered here are said to date later than the 5th century. However, the situation is complicated by the findings within the cave of inscriptions reported to be identical with the Artemis Brauronia texts from the Athenian Acropolis, which are dated to the mid-4th century BC. ${ }^{142}$ Furthermore, the "Small Temple" was apparently also covered by a heavy rockfall and if this is to be taken as the same disaster as that which destroyed the structures within the cave, the "Small Temple" must have been built before the mid-5th century. ${ }^{143}$ Such an early date is supported by the recovery of 6th- and 5th-century material from the cleaning of this building the season after it had been excavated. ${ }^{144}$ On the other hand, since a 4 thcentury, terracotta head was apparently recovered from within the "Small Temple", the building seems to have been in use as late as that. ${ }^{145}$

It seems impossible to reconcile all this conflicting information on the basis of the present evidence. However, a partial solution would be to connect the destruction of the structures within the cave with the plundering of the sanctuary by the Persians in $480 \mathrm{BC}$. At this period, the roof of the cave may still have been intact, but the structures within were damaged by the Persians. After this event, it was decided to abandon the cave and to replace it with the "Small Temple", which was erected in the second half of the 5th century. The 6th- and 5th-century material recovered from within the "Small Temple" then needs to be accounted for, but it may derive from the decayed, mud-brick walls of this building. The "Small Temple" was in use into the 4th

\footnotetext{
138 For the various proposals, see Table 1.

139 Mylonopoulos \& Bubenheimer, l.c. (n. 50), p. 21, arguing for a similarity in plan and proportions between this building and some of the treasuries at Olympia and Delphi.

140 The "Small Temple" is close in scale and layout to the small building at the West Gate beroon at Eretria, often suggested to have been a dining-room; see P. AUBERSON \& K. SCHEFOLD, Fübrer durch Eretria, Berne, 1972, p. 78-80, and C. BÉrard, "Note sur la fouille au sud de l'Hérôon", $A K 12$ (1969), p.75-76.

141 For the "Sacred House", see above, p. 85. Only 6th-and 5th-century material is reported from this building. In the late 5 th century, the diners may also have been moved to the new stoa.

142 See above, n. 8.

143 PAAH 1949, p. 81-83.

144 Ergon 1955, p. 33.

145 PAAH 1949, p. 90 and fig. 19.
} 
century, when there was a major rockfall from the acropolis, destroying the "Small Temple" and causing the cave to collapse and burying the whole area under a layer of boulders. All of this is, of course, very hypothetical and the final publication of the area will clarify these matters.

To conclude this section, the identification of the cave area and the "Small Temple" at its north-western entrance as the tomb and cult place of Iphigeneia on the basis of Euripides' statement in the IT cannot be said to be substantiated by the archaeological evidence, as known at present. Instead, an analysis of the archaeological remains leads to the suggestion that the area was used for the storage of offerings to Artemis and for ritual dining for a certain group of participants or perhaps as accommodation, for example, of the religious office-holders or some of the arktoi (see below, p. 104).

\section{The northern section of the stoa}

The second area which has been connected with the cult of Iphigeneia is located in the late-5th-century stoa, framing the northern section of the sanctuary (Fig. 1, no. 11). The northern part of this building consisted of an open, narrow courtyard or corridor, c. $39.80 \mathrm{~m}$ long and c. $6 \mathrm{~m}$ wide, oriented in an east-west direction and entered by a propylon at each end. Its northern side was formed by a shallow stoa or one-aisled portico facing south, c. $48.35 \mathrm{~m}$ long and $4.35 \mathrm{~m}$ wide (Fig. 1, no. 12, and Figs, $4-5) .{ }^{146}$ Within this stoa was found a row of 37 poros slabs with a central cutting (c. $0.80 \times 0.17 \mathrm{~m}$ ), most likely for some kind of stelai (Fig. 4) ${ }^{147}$ No stone stelai or slabs, whole or fragmentary, seem to have been recovered in the stele bases or in their vicinity. ${ }^{148}$ Furthermore, within the central cuttings of the poros slabs, there seem to have been no traces of lead for fastening stone stelai, as was observed in many of the stele bases along the northern side of the temple terrace and along the west wall of the western wing of the stoa.

Since these bases do not seem to have been regular stele bases for stone stelai, Papadimitriou suggested that wooden boards were inserted into the bases and that the clothes of women who had died when giving birth were displayed on these boards as dedications to Iphigeneia. ${ }^{149}$ Moreover, Kondis remarked that, owing to the width of the boards, the only garments that could have been shown here were peploi, thus constituting a further corroboration of Euripides. ${ }^{150}$ The comparative

146 For the architecture, see Bouras, o.c. (n. 5), p. 127-140, pls. $11 \mathrm{a}-\mathrm{b}$ and $12 \mathrm{~g}$, figs. 96-97; Travlos, o.c. (n. 3), p. 55-56; J.J. Coulton, The arcbitectural development of the Greek stoa, Oxford, 1976 (Oxford monographs on Classical archaeology), p. $42-43$ and 226-227. Excavation reports: PAAH 1949, p. 83-84; PAAH 1959, p. 18-19; Ergon 1956, p. 28; Ergon 1958, p. 31-38; Ergon 1959, p. 13-15; Ergon 1960, p. 21-25; Ergon 1961, p. 20-29; Ergon 1962, p. 37-39.

147 Ergon 1960, p. 25; Eigon 1961, p. 29; Bouras, o.c. (n. 5), p. 124; Kondis, l.c. (n. 3), p. 124.

148 Bouras, o.c. (n. 5), p. 124; Mylonopoulos \& Bubenheimer, l.c. (n. 50), p. 21. However, Hollinshead (l.c. [n. 9], p. 434) claims that this part of the stoa is one of the areas of the sanctuary that has yielded many inscriptions.

149 Ergon 1961, p. 29; Bouras, o.c. (n. 5), p. 124; Cole, l.c. (n. 22), p. 239; Brulé, o.c. (n. 9), p. 236237; Travlos, o.c. (n. 3), p. 55. Others have argued that the bases were for regular stone stelai (e.g. Hollinshead, l.c. [n. 9], p. 434), although this area is curiously devoid of such fragments, particularly compared with the number of stelai fragnents recoverd near the bases to the north of the temple terrace and west of the cave area, where poros bases were found and the bedrock has a number of cuttings suitable for the placing of stone stelai.

150 Kondis, l.c. (n. 3), p. 173-175. 
isolation of this area from the rest of the sanctuary would also argue in favour of its connection with Iphigeneia, since these offerings had an apotropaic function different from the textile offerings to Artemis, given to the divinity dealing with the positive side of childbirth.
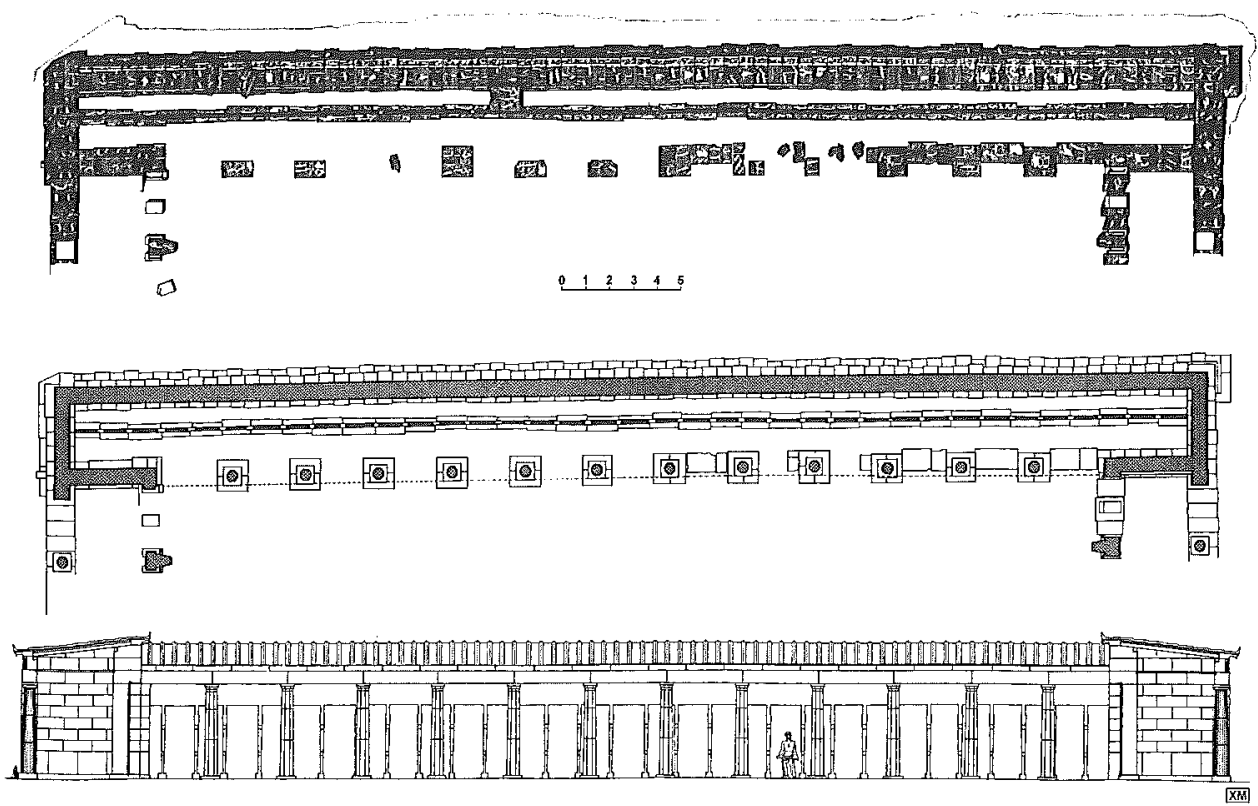

Fig. 4. The northern section of the late-5th-century stoa at Brauron. From Bouras, o.c. (n. 5), figs. 96-97.

Several objections can be raised against this interpretation. First of all, there is no evidence for clothes being displayed on wooden boards in Greek sanctuaries in this manner. Secondly, to exhibit the garments purportedly dedicated to Iphigeneia in this part of the stoa would, in a way, have given the offerings to the heroine a more prominent position than those made to the goddess. Of the clothes given to Artemis, some were displayed on the cult statues standing within the cella of the temple, while other textile gifts also seem to have been housed in the temple, some kept in wooden boxes or trays. ${ }^{151}$ Although storage within the temple must be considered as a prestigious location for votive gifts, the dedications to Iphigeneia would have been far more accessible and noted than those to Artemis, which were perhaps only seen by the religious office-holders. Furthermore, to display the clothes in the open stoa would have exposed them to wind and weather in a manner hardly suitable for textile offerings.

The use of the northern section of the stoa as an exhibition hall for the dead women's clothes has been connected with the parastas and toichos mentioned in

151 Linders, o.c. (n. 8), p. 10-11 and 72; Mylonopoulos \& Bubenhemer, l.c. (n. 50), p. 21. On the number of cult statues, two or three, see Linders, o.c. (n. 8), p. 14-16; 1.B. Romano, "Early Greek cult images and cult practices", in HäGG, Marinatos \& Nordquist, o.c. (n. 124), p. 131-132; J. Tréheux, "Sur le nombre des statues cultuelles du Brauronion et la date de l'Artémis Brauronia de Praxitèle", RA 1964, p. 1-6. 
some of the inscriptions recording dedications. ${ }^{152}$ The identification of the northern section of the stoa as the parastas and the toichos as its back wall is dubious on both epigraphical and practical grounds. ${ }^{153}$ If the contents of the offerings mentioned in the relevant inscriptions are considered, it is clear that they were of a valuable kind. The shallow stoa was an open area, which could not be locked and was thus highly unsuitable for the storing of such dedications. ${ }^{154}$ Furthermore, if the parastas and the toichos are to be located in this part of the stoa, offerings to Artemis must also have been displayed here, since the same inscriptions also list dedications to the goddess. ${ }^{155}$

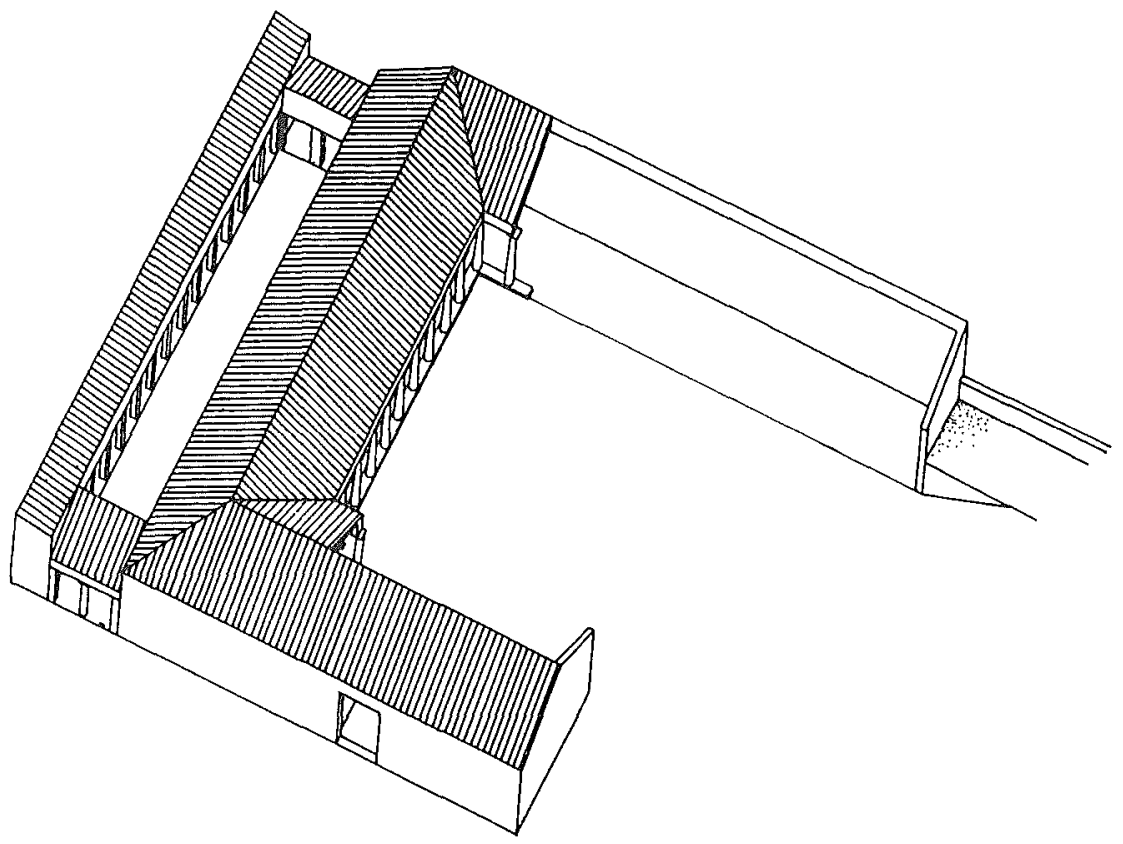

Fig. 5. Isometric reconstruction of the stoa at Brauron.

From Bouras, o.c. (n. 5), fig. 76 b.

On the whole, the interpretation of the northern stoa as an exhibition hall for garments dedicated to Iphigeneia seems implausible, and other possible functions are therefore to be examined. ${ }^{156}$ Considering the coherent layout of the building and the

152 Ergon 1960, p. 25; Ergon 1961, p. 29; Bouras, o.c. (n. 5), p. 122 and 182. For parastas in the epigraphical evidence, see $I G \mathrm{II}^{2}, 1517,52-53 ; 1524,118$ and 123 ; for the toicbos, see $I G \mathrm{II}^{2}, 1517,43$; $1514,23-24(=1515,15-16 ; 1516,3-5)$.

153 LiNDers (o.c. [n. 8], p. 37 and 57) points out that the inscriptions speak of offerings being on or against the door-post pilaster, as well as being on the wall. Parastas can therefore not be a room or a building in these cases.

154 LINDERS, o.c. (n. 8), p. 72, n. 33.

$155 I G \mathrm{II}^{2}, 1514,22-24$ : "clothes [displayed] on the Old Statue, a mirror on the wall, clothes on the Marble Statue". All the offerings recorded in this part of the inscription come from one locality, probably one building; see Linders, o.c. (n. 8), p. 14-15 and 17.

156 A less likely interpretation of this structure is to identify it with the stable known from two inscriptions recovered at Brauron; see Themelis (1974), o.c. (n. 49), p. 20; Id., l.c. (n. 7), p. 230 and 
fact that it must have been constructed to house the entire row of rectangular bases and what was placed in them, a function is to be sought explaining the whole complex. Moreover, all the bases in the stoa seem to have been put into place on one occasion, as a deliberate installation, while the rest of the stele bases found in the sanctuary seem to have been erected there when required. ${ }^{157}$

The suggestion that the bases once held wooden boards is attractive. The use of whitened wooden boards, leukomata or peteura, is known from other sanctuaries, where they were used to record cult regulations, announcements and lists of names and priests, for example. ${ }^{158}$ A further argument for wooden boards is the fact that these bases are placed under a roof, unlike the other stele bases recovered from the sanctuary, most of which are located in the open. ${ }^{159}$ Wooden boards covered with gypsum and with painted or scratched text had, of course, to be protected from the rain. ${ }^{160}$

The courtyard is set off from the central part of the sanctuary and can only be reached from this area by a narrow passage in the centre of the north wing of the stoa. It is easily accessible from the outside, however, having two entrances, one facing west and the main route to Athens and one facing east and the road to the coast and the sanctuary of Artemis Tauropolos at Halai (see Fig. 4). Therefore, whatever was displayed here was meant to be seen and to be easily accessible, though perhaps not directly part of the ritual actions, such as sacrifices and other ritual performances, which presumably took place in front of the temple and in the open area framed by the stoa.

Instead of linking the northern section of the stoa with Iphigeneia, my suggestion is to connect the use of this building with the arkteia, a ritual constituting one of the main features of the religious activity at Brauron and the performance of which is supported by both the literary and the archaeological evidence. I would propose that a possible function of the stele bases in the northern section of the stoa could have

236, n. 36; SEG 37 (1987), no. 35; H. LAUTER, Die Alkitehtur des Hellenismus, Darmstadt, 1985, p. 45. See also Mrlonopoulos \& Bubenhemen, l.c. (n. 50), p. 19.

157 See, for example, the placing of the stele bases along the northern side of the temple terrace and the west wing of the stoa (Bouras, o.c. [n. 5], p. 95, fig. 69).

158 F. Sokolowski, Lois sacrées des citês grecques, Paris, 1969 (École française d'Atbènes: Travaux et mémoires, 18), no, 69, lines 42-43; A. Petropoulou, "The eparcbe documents and the early oracle at Oropus", GRBS 22 (1981), p. 49, lines 42-43 (4th century BC), Amphiareion at Oropos, for recording the names of incubants; IG XII:5, 647, 40 (3rd century BC), Keos, a regulation for sacrifices and athletic festivals; Sokolowski, $\operatorname{LSAM}$ (n. 58), no. 53, lines 35-36 (1st century AD), Miletos, regulations concerning the Molpoi and Prophetes; $c f$. MxLonopoulos \& Bubenheimer, $l . c$. (n. 50), p. 19-21. On wooden boards, see also E.G. Turner, Greek papyri: An introduction, Oxford, 1968, p. 6; R. Thомas, Literacy and orality in ancient Greece, Cambridge, 1992 (Key themes in ancient bistory), p. 83. In the Sacred Spring temenos at Corinth was found a series of rectangular holes apparently for wooden stelai (two examples measuring $0.09 / 0.13 \times 0.23 / 0.24 \mathrm{~m}$ ), erected in the 5th century, see Ch.K. Williams, II \& J.E. Fischer, "Corinth, 1970: Forum area", Hesperia 40 (1971), p. 15 and pl. 4.

159 Stele bases or cuttings for stelai are found along the northern side of the temple terrace, along the south-western wall of the stoa and in front of the cave.

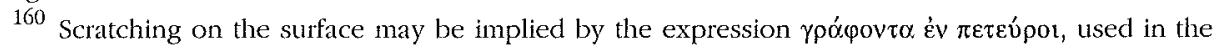
inscription from the Amphiareion; Sokolowski, LSCG (n. 158), no. 69, line 42; Petropoulou, l.c.

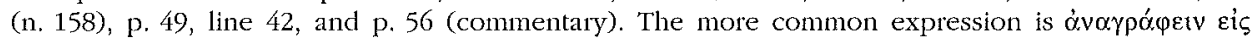

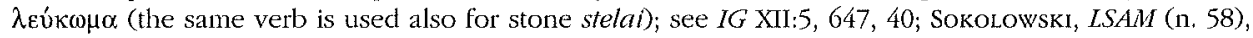
no. 53, lines 35-36; Dem., Contr: Timocr., 23. 
been to house wooden boards on which were recorded the names of all the girls embraced by the arkteia during a certain period of time.

The number of girls actually participating in the ritual at Brauron is not definitely known and estimates have varied between all Athenian girls of the relevant age to only a few privileged ones from rich and prominent Athenian families. ${ }^{161}$ Christiane Sourvinou-Inwood's detailed discussion of the evidence has demonstrated the logistic impossibility of having more than a small number of girls present at the sanctuary for a long period of time. Since the literary sources speaking of the arkteia suggest some kind of tithe, it has been argued that a representative cross-section was made on tribal bases, perhaps one girl from each phyle, selected by drawing lots. ${ }^{162}$ At the same time, the importance of the arkteia as marking an essential stage of maturation in the development of all young, Athenian girls into marriageable women seems to be beyond doubt, whether or not they were actually present at Brauron. ${ }^{163}$ The select number of girls performing the ritual at the sanctuary may therefore have been perceived as being representative of their whole age-group, i.e. four year-crops.

Seen in this perspective, one way of including all Athenian girls of the right age in the arkteia would have been to record all their names on wooden boards each fourth year, when the ritual took place, and to display these in the northern section of the stoa. Even though only a few girls actually stayed at the sanctuary during a certain period of time, the listing of all the names would have been a way to make all the girls participate in a sense and further demonstrate that the arkteia was of concern to them all, whether or not they had been selected to be physically present at Brauron. That names of visitors and worshippers were listed and displayed in Greek sanctuaries with the explicit intention of their being seen by others is clear from a number of cases. A sacred law from the Amphiareion at Oropos, for example, states that the neokoros was to write down the full name of each incubant, as soon as he had paid the fee, and to display the board bearing this information in the sanctuary, so that anyone who so desired was free to inspect the name. ${ }^{164}$

161 Simon (o.c. [n. 20], p. 86) concluded that, owing to the frequency and quality of the kiateriskol connected with the arkleia, the whole Athenian population must have participated. H.W. PARKe (Festivals of the Athenians, London, 1977 [Aspects of Greek and Roman life], p. 140) saw the arkteia as the duty and privilege of a limited number of aristocrats; cf. also Cole, l.c. (n. 22), p. 242. Bonnechere (o.c. [n. 17], p. 29) suggests that only a fer girls from privileged families took part in the arkteia at Brauron and Mounychia, while the general public celebrated the ritual in local sanctuaries.

162 Sourvinou-Inwood (1988), o.c. (n. 17), p. 114-116; cf. Brulé, o.c. (n. 9), p. 206-207; DowDEN,

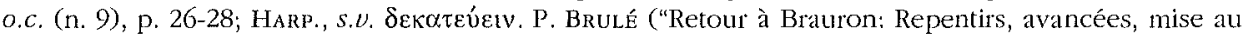
point", DHA 16:2 [1990], p. 71) also suggests that the number of couches in the stoa (99) was not coincidental but was related to the number of tribes (ten) and therefore provided sufficient space for the fathers of the arktoi at the dining taking place in connection with the ritual.

163 Sourvinou-INWOOD (1988), o.c. (n. 17), p. 22 with n. 61; OsBorne, o.c. (n. 2), p. 165; Dowden, o.c. (n. 9), p. 29; Bonnechere, o.c. (n. 17), p. 36-37. The aitia of the arkteia insist that it was necessary for each Athenian girl to have been a "bear" before getting married; cf. HARP., s.u.

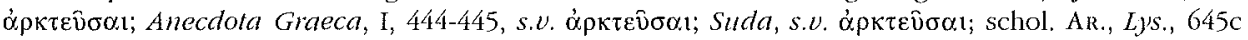
(Hangard),

164 Sokolowski, LSCG (n. 158), no. 69, lines 39-43; Petropoulou, l.c. (n. 158), p. 49, lines 39-43:

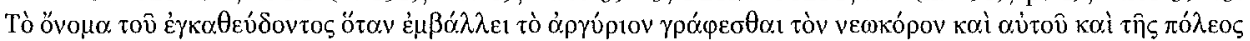

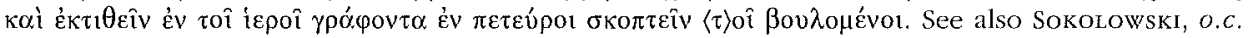
(n. 158), no. 93, lines 8-14, Eretria, 4th or 3rd century BC, to note the names of the children participating in the procession at the Asklepieia and display the leukoma in the sanctuary; Sokolowski, LSCG (n. 158), no. 83, lines 30-37, Korope, c. 100 BC, write down the names of those 
According to Sourvinou-Inwood's calculations, the total number of girls from one year-crop would amount to around $600-700$, which adds up to a considerable number of names each fourth year, when the arkteia was performed. ${ }^{165}$ The recording of such a quantity of text must have been a laborious work, even though it took place only each fourth year. Since the display of the names was probably only of relevance for a certain period of time (three or four years), the painting or scratching of the names on the boards would have been both cheaper and less timeconsuming than inscribing them on stone slabs. ${ }^{166}$ The same boards could later have been whitewashed and re-used. ${ }^{167}$ Even though the display of these documents was set off from the main part of the sanctuary, unlike the stone inscriptions recording the inventories of the offerings, which have mainly been found close to the temple, the wooden boards were still highly accessible and visible to those visiting Brauron in connection with festivals, for private religious errands or just passing by. ${ }^{168}$ Moreover, the location of the stele bases in the stoa facing the narrow, open courtyard would have provided the boards with enough light to make them easy to see and read. ${ }^{169}$

Sourvinou-Inwood has stressed the importance of the arkteia as a ritual embracing the whole polis and, in a way, functioning as a female counterpart to the epbebeia for the young men. ${ }^{170}$ She has further suggested that the arkteia was of high, ideological concern and, in the context of Kleisthenes' reforms, that the ritual was shaped to express and validate the new articulation of the polis as a democracy and its cohesion. Bearing this in mind, what would have been more democratic than to name in public all the girls undergoing the transformation into future wives and mothers of new citizens? Furthermore, that fact that the arkteia marked the girls as entering the age when they could be married is also of interest here and the listing of the names may have been one way of presenting all the girls eligible for marriage in

who are to consult the oracle and display the leukoma in front of the temple; cf. ibid., no. $154 \mathrm{~A}$, lines 12-18, Kos, c. 300-250 BC; no. 166, lines 32-35, Kos, 2nd or 1st century BC; no. 173, lines 65-102, Halasarna, c. $200 \mathrm{BC}$.

165 Sourvinou-Inwood (1988), o.c. (n. 17), p. 116. For other attempts to calculate the number of arktoi, see Dowden, o.c. (n. 9), p. 27-28; cf. Brulé, o.c. (n. 9), p. 370-376. Since the arkteia was celebrated also at Mounychia, it is possible that only half the number of girls were connected with Brauron.

166 The same reasoning must have lain behind the use of wooden boards for proposals for decrees to go before the Athenian assembly, only some of which were later cut in stone; see Thomas, o.c. (n. 158), p. 83; cf. IG XII:5, 647, 40-43 (= SoKolowski, LSCG [n. 158], no. 98).

167 Petropoulou (l.c. [n. 158], p. 56) suggests that the boards used at the Amphiareion were coated with a new layer of white substance when the surface had been filled with writing.

168 The stone inventories seem to have been put up at the locations where the actual offerings were kept; see Linders, o.c. (n. 8), p. 72; Hollinshead, l.c. (n. 9), p. 434.

169 The limited extent of literacy in antiquity is an argument against the assumption that Greek inscriptions were put up with the intention of providing the public with information. Still, literacy allowing the decoding of names seems to have been more widespread; see Thomas, o.c. (n. 158), p. $8-12$.

170 Sourvinou-Inwood (1988), o.c. (n. 17), p. 111-113; cf. Cole, l.c. (n. 22), p. 233-244, comparing the arkteia to the koureion for the boys. Incidentally, in the Classical period, the names of the ephebes seem to have been written on leukomata, which were then displayed; see Ch. Pélékidis, Histoire de l'épbébie attique des ortgines à 31 avant Jésus-Christ, Paris, 1962 (École française d'Athènes: Travaun et mémoires, 13), p. 73 and 100-101. 
the near future. ${ }^{171}$ The lists with the names perhaps also functioned as a means of demonstrating their proper Athenian ancestry. This aspect may have been particularly important as a result of Perikles' citizenship laws of 451/0 BC, according to which an Athenian citizen had to be of citizen descent on his mother's side as well as his father's. ${ }^{172}$

\section{The adyton of the temple of Artemis}

The third part of the sanctuary at Brauron suggested to be related to Iphigeneia is the adyton of the temple of Artemis (Fig. 1, no. 1). In an article comparing the layouts of the three temples of Artemis at Brauron, Halai/Loutsa and Aulis, John Travlos argued that, since all these temples had adyta, taken to be a characteristic feature of shrines of chthonian divinities, there must have existed a chthonian aspect of the cult at each of these three locations. ${ }^{173}$ At all three sites, Iphigeneia would have been the chthonian side of Artemis, having her cult housed in the adyton of the temples of the goddess.

In a re-study of these three temples, Mary Hollinshead refuted the hypothesis of the adyta housing any form of ritual activity or being connected with Iphigeneia. ${ }^{174}$ At Halai/Loutsa and Aulis, there is, in fact, no evidence to support a cult of Iphigeneia and an analysis of the archaeological material suggests that the presence of adyta at these sites may be explained as a result of particular local traditions or as later additions to the original layout of the temple. ${ }^{175}$ In the case of Brauron, Hollinshead suggests that the adyton served as a storage facility for valuable goods rather than any cultic purpose. ${ }^{176}$ This interpretation of the adyton at Brauron is supported by the number of offerings found to the north and north-west of the temple terrace. ${ }^{177}$ Though most of these objects seem to have been intentionally deposited at the spring, some of this material may be taken to represent the remains of the dedications once kept in the adyton, which ended up north and north-west of the temple terrace

171 On the arkteia being part of a larger festival aiming at the reunion of the sexes, as well as showing off the girls for marriage, see Dowden, o.c. (n. 9), p. 40-41 and 200; Id., I.c. (n. 40), p. 39. Cf. C. Calame, Les cboeurs de jeunes filles en Grèce archä̈que. I. Morpbologie, fonction religieuse et sociale, Rome, 1977 (Filologia e critica, 20), esp. p. 445-447, on religious festivals, choruses and dancing in particular, functioning as a means of presenting the young girls to the community and as a preparation for their subsequent marriage.

172 On Perikles' law, see C.B. Patterson, Pericles' cilizenship law of $451 / 0$ BC, Ph.D. Diss, University of Pennsylvania, 1976, passim and esp. p. 79-80, 176-179 and 221-229; WHITEHEAD, O.C. (n. 2), 71-72 and 98-99; P.J. Rhodes, A commentary on the Aristotelian Athenaion Politeia, Oxford, 1981, p. 331-335 and 496-497; C.B. PATterson, The family in Greek bistory, Cambridge \& London, 1998, p. 109-110. It cannot be shown that the law was revoked or modified between its enactment in 451/0 and its re-enactment in 403; see Ead. (1976), supra, p. 221-229. That the law was still in force late in the century is evident from AR., Av., 1649-1661, the play being performed in $414 \mathrm{BC}$.

173 Travlos, l.c. (n. 38), p. 197-205, esp. 197-198 and 204, fig. 8; cf. KaHl (1977), l.c. (n. 6), p. $86-$ 98; Ead., l.c. (n. 46), p. 77; Brulé, o.c. (n. 9), p. 193-195; Dowden, o.c. (n. 9), p. 38. For the remains of the adyton of the temple at Brauron, see Travlos, o.c. (n. 3), p. 53 and 61, fig. 58; PAAH 1945-1947. 1948, p. 86; PAAH 1949, p. 75-77; PAAH 1955, p. 118; PAAH 1956, p. 74, fig. 1; Eigon 1955, p. 33.

174 Hollinshead, l.c. (n. 9), p. 419-440.

175 Hollinshead, l.c. (n. 9), p. 423-424, 427-428, 430-432 and 435-439.

176 HOLlinshead, l.c. (n. 9), p. 432-435 and 438-439.

177 Ergon 1961, p. 30-34; PAAH 1959, p. 19; Engon 1959, p. 16; cf. Ergon 1962, p. 27-28; see also the discussion above, p. 79-82. 
when the temple was plundered and destroyed by the Persians in $480 \mathrm{BC}$ or were dumped there during the subsequent cleaning up of the temple site. ${ }^{178}$

Travlos' interpretation of the adyton as linked with Iphigeneia was based on the assumption that a chthonian divinity demanded particular kinds of cultic installations, adyta being one of these. In a second study, Hollinshead has demonstrated the unsuitability of the term adyton for the inner room of a Greek temple, in particular, since the application of the term easily carries with it assumptions of particular divine recipients and rituals, especially secret rites, which are not supported by the archaeological evidence. ${ }^{179}$ Furthermore, temples with an inner room cannot be connected with any particular divinity nor be taken as a sign of "chthonian" activity. Instead, such rooms were in general used for storage and safekeeping, apart from a few cases in which an oracular function can be demonstrated. ${ }^{180}$ The location of Iphigeneia's cult in the adyton of the temple at Brauron has therefore no factual support and is based only on the supposition of the existence of particular chthonian traits and rituals. ${ }^{181}$

To sum up, the archaeological evidence at Brauron, as known at present, cannot be said to corroborate the assumptions of a cult of Iphigeneia, made on the basis of the literary sources. There is no archaeological support for identifying the cave area and the adjacent buildings as the tomb or beroon of Iphigeneia. The find material from this part of the sanctuary cannot be said to demonstrate her presence at this particular location but rather indicates that the cave was connected with the same divinity as the rest of the sanctuary. More specifically, certain sections of the cave may have been used as storage space for votive offerings made to Artemis, while other parts functioned as a dining facility and could perhaps also be used as accommodation, perhaps for religious office-holders. The northern section of the stoa, suggested to house the clothes dedicated to Iphigeneia, is better explained as having been used for sheltering wooden boards listing the names of all the girls embraced by the arkteia during a certain period of time. Finally, a particulat connection between the inner room or adyton within the temple of Artemis and a chthonian cult of Iphigeneia is not supported by the comparative evidence, either the archaeological or the written, and this part of the temple was rather used for the safekeeping of valuable offerings.

\section{De-constructing Iphigeneia}

The analysis of the evidence from Brauron presented above points in the direction of a re-evaluation of Iphigeneia's presence and cult at the site and of the literary sources supporting them. Bearing in mind that the site is mainly known from preliminary reports, it still seems clear that Iphigeneia is remarkably absent from the epigraphical and iconographical, as well as the archaeological material. Furthermore,

178 In particular, the material found in the ashy layer just to the north of the terrace wall; see supra, n. 108; cf. Ergon 1961, p. 31-32. There is no mention of Iphigeneia on any of the objects recovered here, while at least one bronze mirror had an inscribed dedication to Artemis; see supra, n. 52.

179 M.B. Hollinshead, "Adyton', 'opisthodomos' and the inner room of the Greek temple", Hesperia 68 (1999), p. 189-218.

180 Hollinshead, l.c. (n. 179), p. 189-218, esp. 195-199 and 214.

181 Cf. Hollinshead, l.c. (n. 179), p. 198. On the difficulties in applying the concept of "chthonian" to Greek religion, in particular, the archaeological evidence, see above, p. 82-83. 
the buildings and structures usually connected with Iphigeneia can be interpreted as having different functions than those traditionally proposed and these functions can be integrated in the development of the sanctuary both synchronically and diachronically (see further the Appendix).

Altogether, there is at present no evidence which supports or confirms Euripides' statements, nor are there any indications of a pre-Euripidean presence of the heroine at the sanctuary. At the end of this inquiry, Iphigeneia still remains an evasive literary figure more than an actual recipient of cult. Where does all this leave Euripides and the other literary sources connecting Iphigeneia and Brauron? The crux of the matter is, in fact, Euripides, since the information in scholia on Aristophanes' Lysistrata (645) cannot be demonstrated to pre-date him. In any case, the scholia, including the quotation from Euphorion, do not provide any independent evidence, since it cannot be excluded that their information may be a result of influences from Euripides. We should therefore consider the possibility that Iphigeneia's presence at Brauron, her tomb, cult and particular votive practices are an Euripidean invention. Though such a conclusion may at first seem too bold to be accepted, it may be argued that we are here dealing with an aition which is a literary construct rather than an account of the actual ritual practices of an Athenian cult.

It is, of course, still possible that Iphigeneia was present at or connected with Brauron in a way which has left no traces either in the previous literary record or in the archaeological remains so far known from the site. ${ }^{182}$ She may have been a predecessor of Artemis or an aspect or epithet of the goddess or a mythical figure linked to Brauron, perhaps not even called Iphigeneia to begin with, to whom Euripides ascribed cultic functions as well. ${ }^{183}$ This may have been the case, but it has to be remembered that the antiquity of Iphigeneia still remains an inference not supported by any direct evidence. Euripides is the earliest source to connect Iphigeneia with Brauron in any sense and also the source that provides the most explicit evidence for her cult at the sanctuary.

The story of Iphigeneia was known in various versions, but the variant presented by Euripides in the IT differs in certain respects from the other known accounts. According to the other versions, including Euripides' own Ipbigeneia at Aulis, Iphigeneia was either saved by Artemis, transported to Tauris and made immortal or simply died at Aulis. ${ }^{184}$ In the IT, Euripides is reshaping the story, so that his version is the only one in which Iphigeneia survives without being given any immortal qualities and is instead said to die a peaceful death. ${ }^{185}$

182 WolfF (l.c. In. 23], p. 323, n. 39) suggests that Phanodemos, FGIHist, 325, F 14, the scholia on Ar., Lys., 645a-b (Hangard) and EupHorion, all connecting Iphigeneia and Brauron, may reflect such earlier elements.

183 The suggestion that Iphigeneia was an older, even prehistoric, birth goddess, has been based on the interpretation of her name, alleged to mean "strong in birth"; see Brulé, o.c. (n. 9), p. 267, n. 89; cf. WolfF, l.c. (n. 23), p. 320, n. 34; Aretz, o.c (n. 9), p. 33-36. Dowden (o.c. [n. 9], p. 46), however, argues that "Iphigeneia" is rather to be understood as "born beautiful".

184 Made divine or given an immortal quality: Stasinos (ap. Proklos, Chrestomatbia [Allen, p. 104, 12-201), Hes., fr. 23a, 17-26 and 23b (Merkelbach \& West), STesichoros, fr. 215 (PMG), Eur., IA, 1607-1608, 1614 and 1622. Died at Aulis: Pind., Pytb., XI, 22-23, Aesch., Ag., 114-138, Soph., El., 566. On the conflicting versions, see also A.O. Hulton, "Euripides and the Iphigenia legend", Mnemosyne 15 (1962), p. 364-368.

$185 \mathrm{It}$ is interesting to note that, at the end of the $I A$, produced posthumously in $405-c .400 \mathrm{BC}$, Euripides makes no mention of Iphigeneia's return to Brauron and only states that she was 
Furthermore, Euripides is the first author who describes Iphigeneia's return to Greece from Tauris and it may also have been he who brought Orestes into the story. ${ }^{186}$ Bearing this in mind, it is tempting to suggest that her particular connection with Brauron is a further Euripidean elaboration or invention and that it may, in fact, have been Euripides who located Iphigeneia in Brauron in the first place. It may not be coincidental that, in the $I T$, Iphigeneia is described as coming to a sanctuary of Artemis which was already in existence, contrary to Orestes, who was to build a new temple at Halai and there set up the statue of Artemis Tauropolos ${ }^{187}$ Her arriving at a cult place already in use can perhaps be taken as an indication that Iphigeneia was actually added to Brauron at a late stage.

Since Euripides elaborated on the Iphigeneia story as regarded her whereabouts after coming to Tauris, it is also of interest to take a closer look at what kind of rituals he outlined for Iphigeneia at Brauron and to see how they compare with Greek cult at large. ${ }^{188}$ In the case of Brauron, Euripides states that Iphigeneia was to be given the clothes from women who had died in childbirth. One further reason for doubting that Euripides is describing an actual, practised cult of Iphigeneia at Brauron is related to this particular ritual. There seem, in fact, to be no known parallels to this kind of ritual practice anywhere else in the Greek world. ${ }^{189}$ As far as we can tell, all other dedications of clothes made in connection with childbirth were made by women who had survived the delivery.

Moreover, if the clothes of those who perished in giving birth were dedicated in a sanctuary, what were they supposed to achieve? ${ }^{190}$ For a pregnant woman to die while giving birth was a disaster, not only for the woman herself, the child and her family, but also because she did not fulfil her role as a woman. If this could be avoided in the future by dedicating the dead woman's clothes to a certain divinity, one would expect that dedications of this kind would be common in sanctuaries dealing with women and childbirth. To prevent the death of other mothers-to-be would have been of prime concern for the families.

Not only the lack of parallels to the offering of dead women's clothes ought to raise our awareness but also the fact that the wider content of this ritual is highly unusual, if seen within the context of Greek votive practices at large. Dedications in sanctuaries were made in order to get protection and help from the gods in the future

sacrificed and saved and is now to be found among the gods (IA, 1607-1608, 1614 and 1622). On the difficulties about the authenticity of the exodus of this play, see above, n. 12. It seems clear, however, that the contents are those of the original version; see also Eur., fr. $587\left(\mathrm{Nauck}^{2}\right)$.

186 Cf. Aretz, o.c. (n. 9), p. 37. According to Pausanias (I, 33, 1), Iphigeneia returned to Argos after having brought Artemis' image back to Brauron. On Orestes, see Hulton, l.c. (n. 184), p. 368.

187 On Iphigeneia going to a pre-existing place of worship, see WolfF, I.c. (n. 23), p. 319-320. Athena does not order Iphigeneia to found the cult at Brauron in the same sense that she commands Orestes to found Halai, as has been claimed by, for example, Ch. Sourvinou-Inwood, "Tragedy and religion: Constructs and readings", in Ch. Pebley (ed.), Greek tragedy and the bistorian, Oxford, 1997, p. 174-175.

188 Cf. F.M. DunN, Tragedy's end. Closure and innovation in Euripidean drama, New York \& Oxford, 1996, p. 63.

189 Cf. WolfF, l.c. (n. 23), p. 320 and 323. Platnauer in his commentary on the IT (o.c. [n. 75], p. 178 , line 1465$)$ is mistaken.

190 JoHnston (o.c. [n. 55], p. 239-240) suggests that the offerings may have been made for the good of the rest of the family, especially the infant, if it had survived, or any future children the husband may have, as well as his future wife. 
or as thank-offerings when this help and assistance had been forthcoming. ${ }^{191}$ To commemorate, in a sanctuary, the dreadful misfortune of a woman dying when giving birth seems to have been contrary to the basic principle of Greek votive religion. It is true that the dedication of war spoils to the gods also involved someone's misfortune and death, but the objective behind such offerings was gratitude to the gods who had contributed to the victory rather than the commemoration of the enemies who had died. Therefore, this particular ritual at Brauron may also be taken as an Euripidean creation.

Bearing all of this in mind, the suggestion that Iphigeneia's presence and cult at Brauron is an invention by Euripides may still seem too daring to be accepted. One reason for this can definitely be found in our scholarly tradition of having great confidence in what the literary sources tell us about antiquity. In accordance with our Christian tradition, in which we have the text of the Bible as a guideline, we subconsciously tend to regard any explicit written information on religion and cult practice as definite and correct. Greek religion, however, was flexible and multifaceted, with no written rules or dogma and no institutionalized priesthood. Thus, Euripides could very well speak of rituals that did not have an equivalent in actual, practised religion, without this being seen as committing sacrilege or as being a nuisance to his audience. The nature of Euripides as a source for Greek religion has to be kept in mind here: the text in question was a tragedy, not a handbook by a Kultschriftsteller: ${ }^{192}$ Furthermore, recent work on Euripides has demonstrated his flexible use of myth, reshaping the familiar stories, adding new details or episodes and emphasizing new aspects of the legends. ${ }^{193}$ The aetiologies dealing with religion, frequently used in particular as endings of his plays, can in several cases be demonstrated to be inventions. ${ }^{194}$ The case of Eurystheus, outlined in Heracles (10301036), who is to be buried in Athens and to protect the city but explicitly demands not to be given a cult, is one such example, and the institution of a cult to the children of Medea by their mother; who in fact killed them, has also been suggested to be a literary construct. ${ }^{195}$

It is therefore possible that Euripides located Iphigeneia in Brauron and supplied her with a cult there. This scenario, however, was only feasible since the

191 See F.T. van Straten, "Gifts for the gods", in H.S. Versnel (ed.), Faith, bope and woisbip: Aspects of religious mentality in the ancient world, Leiden, 1981 (Studies in Greek and Roman religion, 2), p. 88-104.

192 For the distinctions between paganism and monotheism and how they affect the source material and our modern attitudes to it, see SCuLlion, 1.c. (n. 16), p. 217-233, esp. 218.

193 Dunn, o.c. (n. 188), p. 56-57 and 152-153; Scullion, l.c. (n. 16), p. 217-233; Hulton, l.c. (n. 184); cf. J.D. Mikalson, Honour tby gods: Popular religion in Greek tragedy, Chapel Hill \& London, 1991, p. 235. On Euripides' intellectual relation to myth, see F. JOuAN, Euripide et les légendes des chants cypriens: Des origines de la guerre de Troie à l'Iliade, Paris, 1966 (Collections d'études anciennes), p. 440-459. On Iphigeneia and the IT, see Brelich, o.c. (n. 17), p. 243, who comments that Euripides is not likely to have invented a myth but could very well have introduced new elements. KaHIL (l.c. [n. 27], p. 719) comments that Iphigeneia's role at Brauron might have been a literary invention by Euripides, had it not been confirmed by excavation. Also the new epithet for Artemis in the IT, Tauropolos, has been suggested to be an Euripidean invention; see WOLFF, l.c. (n. 23), p. 313, n. 11.

194 DunN, o.c. (n. 188), p. 56-57, 60-63 and 94-95; Scullion, l.c. (n. 16), p. 217-233.

195 Medea, 1378-1383. See Scullion, l.c. (n. 16), p. 217-233, who also discusses the burial of the knife and the anachronistic treaty between Athens and Argos in Suppl., 1205-1212, and the rituals at Halai and Brauron outlined in the $I T$. 
contemporary cultic situation at this site offered both rituals and divinities from which he could create a cultic persona for Iphigeneia. Her close link with Artemis was, of course, already self-evident. Geographically, she had been previously connected in the epic tradition with Aulis, a coastal sanctuary of Artemis in many respects similar to Brauron. One important reason, however, for placing her at Brauron and not at another sanctuary of Artemis may have been that the arkteia was performed here. The story of Iphigeneia could be correlated to the myths serving as the aitia for the arkteia, since both concerned an animal sacred to Artemis and a young girl or girls having to be sacrificed to placate the anger of the goddess. Moreover, the context of Iphigeneia's sacrifice was marriage, an event which was central also to the arkteia, since the purpose of the titual was to prepare the young girls for this future event. Still, and it is important to note this, there are many distinctions between, on the one hand, the myths behind the arkteia and what the arktoi did at Brauron and, on the other, what happened to Iphigeneia at Aulis and her future functions at Brauron. The ritual and the myths of the arkteia could very well have existed and functioned without Iphigeneia, i.e. it is not necessary to have her present at Brauron in order to explain the arkteia. ${ }^{196}$ And, as far as we can tell, Euripides makes no reference to the arkteia. The connections between Iphigeneia and this ritual are found only in the post-Euripidean sources.

That Iphigeneia was to be the priestess of the goddess also at Brauron is not surprising, since this was her relation to Artemis at Tauris. Furthermore, if Iphigeneia was to be transferred back to Greece, she must be given a function and, since marriage was excluded, a continued service as the goddess's virgin priestess seems to be the only option. To have a priestess of a god or goddess buried in the sanctuary is a pattern known from other cults and sanctuaries. ${ }^{197}$

The most interesting part of Euripides' text concerns the dedication to Iphigeneia of the clothes belonging to women who had died when giving birth. This statement has led some scholars to suggest that Iphigeneia and Artemis at Brauron were two distinct divinities, the former being the negative counterpart of the goddess and dealing with the ill outcome of childbirth. ${ }^{198}$ This role ascribed to Iphigeneia seems to be more a result of a too strong belief in Greek religion being divided into an Olympian and a chthonian sphere, each being the other's opposite, than a reflection of the cultic reality. ${ }^{199}$ The particular and unique, votive ritual consisting of the dedication of dead women's clothes may, in fact, have been constructed from

196 Even Sourvinou-INwood (1990), l.c. (n. 17), p. 52-54, a firm believer in Iphigeneia's intimate connection with the arkteia, admits that the transformation Iphigeneia underwent (saved from sacrifice and turned into the goddess's virgin priestess) is completely different from that of the arktoi (losing their wild element in order to be able to marry eventually). See also KEARNs, l.c. (30), p. 101, pointing to the gap between what the arktoi did and what they presumably heard about Iphigeneia.

197 See Farnell, o.c. (n. 74), p. 53-70, for references. If the priestesses of Artemis used the cave for ritual meals or even stayed there, as was suggested above, the rubble from the collapsed cave may perhaps have constituted a source of inspiration for the claim that the sanctuary housed Iphigeneia's tomb.

198 Kondis, l.c. (n. 3), p. 161; Brulé, o.c. (n. 9), p. 233; cf. Wolff, l.c. (n. 23), p. 320. On Iphigeneia's particular connection with childbirth, as indicated by the etymology of her name, see above, n. 183 .

199 On the lack of distinct evidence for such a separation between Artemis and Iphigeneia, see KEARNs, o.c. (n. 31), p. 29. On the difficulties of applying the Olympian-chthonian distinction to Greek hero-cults, see Eкroth, o.c. (n. 1). 
various aspects of the cult of Artemis. The dedication to Artemis of clothes after childbirth is a practice well documented in the cult of this goddess and at Brauron she also shows a strong, kourotrophic aspect. ${ }^{200}$ Artemis was, however, not only concerned with the positive sides of motherhood but was also regarded as terrifying for women giving birth, striking them with a sudden death. ${ }^{201}$ The dark, dangerous and death-related traits ascribed to Iphigeneia can therefore be found in Artemis as well. Since there seems to be no evidence that Artemis (or any other divinity) received the clothes of dead women, either at Brauron or elsewhere, it is possible that these different sides of the goddess, both as a protector and a destroyer of pregnant women, were modified by Euripides and assigned to Iphigeneia. ${ }^{202}$

When evaluating the ritual centring on the commemoration of women dying in childbirth, it is also of interest to consider this practice within the wider context of the other rituals mentioned in the IT. This is indeed a tragedy full of unusual and uncanny, ritual behaviour. First of all, there are the explicit human sacrifices to Artemis Taurica (IT, 38-41, 380-390 and 609-635) and the fact that the whole startingpoint of the Iphigeneia story is herself being sacrificed at Aulis. Two-thirds of the way through the play, Euripides also gives an aition for the Choes in Athens, focusing on the establishment of this ritual as a response to Orestes' polluted state. ${ }^{203}$ Finally, in the cult of Artemis Tauropolos at Halai, human blood is to be drawn from the neck of a man with the help of a sword. ${ }^{204}$ Some of the ritulal practices outlined here are depicted as having a clear, foreign and barbarian origin and it is doubtful to what extent, if any, they formed part of contemporary Athenian religion. ${ }^{205}$ This concerns in particular the human sacrifice, a kind of ritual not practised by the Greeks of the historical period, and the drawing of human blood at Halai, an action which has no parallel in other Greek cults. ${ }^{206}$ Seen against this setting, it is possible that the ritual outlined for Iphigeneia at Brauron was just one among several poetic elaborations of the Athenian cultic practices by Euripides in creating this play.

A final reason for locating Iphigeneia in Brauron may have been the presence of another divinity at this site, Hekate. Sarah Johnston (who believes that there was a cult of Iphigeneia at Brauron) has suggested that Iphigeneia belongs to the category of "the dying virgin", a female who died because of the wrath of a certain goddess

200 On Artemis as kourotrophos, see KaHil, l.c. (n. 22), p. 802.

201 Call., Hymn. III. In Dianam, 126-127; cf. E. CAHEN, Les bymnes de Callimaque: Commentaire explicatif et critique, Paris, 1930 (BEFAR, 134bis), p. 123, line 127, for commentary and further references. See also $\mathrm{Anl}$. Pal., VI, no. 348; a woman has died in childbirth and the poet asks Artemis if she cares only for dogs and hunting; cf. KEARNS, o.c. (n. 31), p. 29. On Artemis' association with cruel and bloody rituals, see also W. Burker'T, Greek religion: Archaic and Classical, London, 1985, p. 152.

202 The etymology of Iphigeneia's name may also have influenced Euripides to connect her with childbirth; see Sculion, l.c. (n, 16), p. 227; on Iphigeneia and childbirth, see also Kearns, o.c. (n. 31), p. 27-29. For the possible meanings of the name Iphigeneia, see above, n. 183.

203 IT, 947-960; cf. WoLFF, l.c. (n. 23), p. 325-326.

204 IT, 1441-1460, esp. 1458-1460.

205 On this theme, see Scullion, l.c. (n. 16), p. 225-226 and 229; Sourvinou-Inwood, l.c. (n. 187), p. 171-175; cf. Hughes, o.c. (n. 26), p. 135-136. On the violent contents of the cults described in the IT, see WolfF, I.c. (n. 23), p. 318-324.

206 On human sacrifices, see Bonnechere, o.c. (n. 17), passim, esp. p. 311-318; Hughes, o.c. (n. 26), passim, esp. p. 185-193. On Halai, see Duns, o.c. (n. 188), p. 63; Wolfr, l.c. (n. 23), p. 323, n. 40 . 
and who may come back after death to harm virgins, mothers and babies and therefore needs to be placated with a cult. ${ }^{207}$ Johnston further argues that, when Hekate entered Greece in the Archaic period, she was both a protector of women and children and a leader of the restless dead. As such, she partly overlapped with Artemis and continued to have the same functions as this goddess in cult, while in myth she was linked to the dying virgins often connected with the cult of Artemis.

If there existed an earlier cult of Iphigeneia at Brauron, of which we have no trace, Hekate may have been linked to her as well as to Artemis. However, it may be that the presence of Hekate at Brauron actually made it possible for Euripides to place Iphigeneia here. Admittedly, the evidence for Hekate at Brauron is not very extensive, but she is represented in the form of a small, Hellenistic statue and probably also in the late-5th-century "Relief of the gods", which seems to depict the main divinities of the sanctuary. ${ }^{208}$ Hekate may have existed at Brauron in connection with Artemis, perhaps dealing with the negative sides of delivery. ${ }^{209}$ In myth, a connection between Iphigeneia and Hekate is found as from the early Archaic period and Iphigeneia is after her death even transformed into Helkate. ${ }^{210}$ These links between Hekate, Artemis and Iphigeneia may have been further exploited by Euripides.

Altogether, after considering the evidence for Iphigeneia's presence at Brauron literary, epigraphical, iconographical and archaeological - I would conclude that Euripides elaborated on the story of Iphigeneia by locating her in Brauron, letting her die and be buried there and, most of all, making her a figure of cult. From the divinities already present at the sanctuary and the important rituals connected with Brauron, he constructed a new role for Iphigeneia. This Euripidean treatment of a well-known myth, resulting in a different outcome of the story, is far from unique and this literary construction of Iphigeneia is probably what lies behind the tradition of a cult of Iphigeneia at Brauron which we see reflected in the later literary sources. Why Euripides chose to present this version of Iphigeneia in this tragedy, we can only speculate. The general popularity of the Iphigeneia story may have led him to want to create his own version, particularly so, since his interest in variations on familiar myths is well documented. The importance of Brauron in the 5th century, not least as a seat for the arkteia, may also have triggered his interest in this particular sanctuary. The reconstruction work at the site, as well as the construction of the great stoa, which was finished around $420 \mathrm{BC}$, must also have put the sanctuary in focus and may have constituted a further source of inspiration in writing the Ipbigeneia among the Taurians, which was probably performed in 413 .

In the end, we are faced with different sets of sources which are hard, if not impossible, to reconcile: the explicit, literary evidence and the incomplete, silent,

207 JOHNSTON, O.c. (n. 55), p. 238-249.

208 For references, see above, p. 73, with n. 70; cf. Brulé, o.c. (n. 9), p. 196. Some of the terracotta relief plaques found at Brauron show a female figure carying a torch and accompanied by a dog and are perhaps also to be seen as references to Hekate; see Mirsopoulos-Leon, l.c. (n. 69), p. 364. On the connection between Artemis and Hekate in the Artemision at Peiraieus, see Brut.é, o.c. (n. 9), p. 188.

209 Johnston (o.c. [n. 55], p. 203-215 and 241-249) has argued that Hekate gradually came to be seen as associated with the restless dead and with vengeful ghosts, particularly those of young women who died prematurely and did not fulfill their roles as wives and mothers.

210 For Hekate-Iphigeneia in myth, see supra, n. 67. Cf. Johnston, o.c. (n. 55), p. 247. 
archaeological material. How we choose to proceed is partly a question of methodology. Is the written word to be taken as the more reliable one, as has usually been done in the study of Greek religion? Or is our interpretation to be guided by the accumulated and comparative evidence which has emerged over the years from the study of the archaeological material from a number of sites connected with Greek religion? The fact remains that, if we are to take Euripides to be describing an actual, practised cult of Iphigeneia at Brauron, complete with her chthonian character, having a burial and cult place located in a cave and the adyton of the temple and a gallery for the display of the dead women's clothes offered to her, we have to treat the archaeological evidence as mute and adaptable, ready to be fitted into whatever frame the literary sources provide us with. On the other hand, if the archaeological material is approached outside the framework of our preconceived notions of Greek religion, which to a large extent are based on the literary sources, it is possible to reach different conclusions and even challenge the written word.

Gunnel Eкroth

Department of classical archaeology

and ancient history

Stockholm University

SE - 10691 STOCKHOLM 


\section{Appendix}

\section{The development of the sanctuary at Brauron}

In this Appendix, a proposed development of the sanctuary, both synchronically and diachronically, will be presented, in order to demonstrate the plausibility of the suggested re-interpretations of the buildings usually connected with Iphigeneia and her cult. The development of the sanctuary may be divided into five phases, from its foundation in the Geometric period to its abandonment in antiquity and re-use as a Christian site.

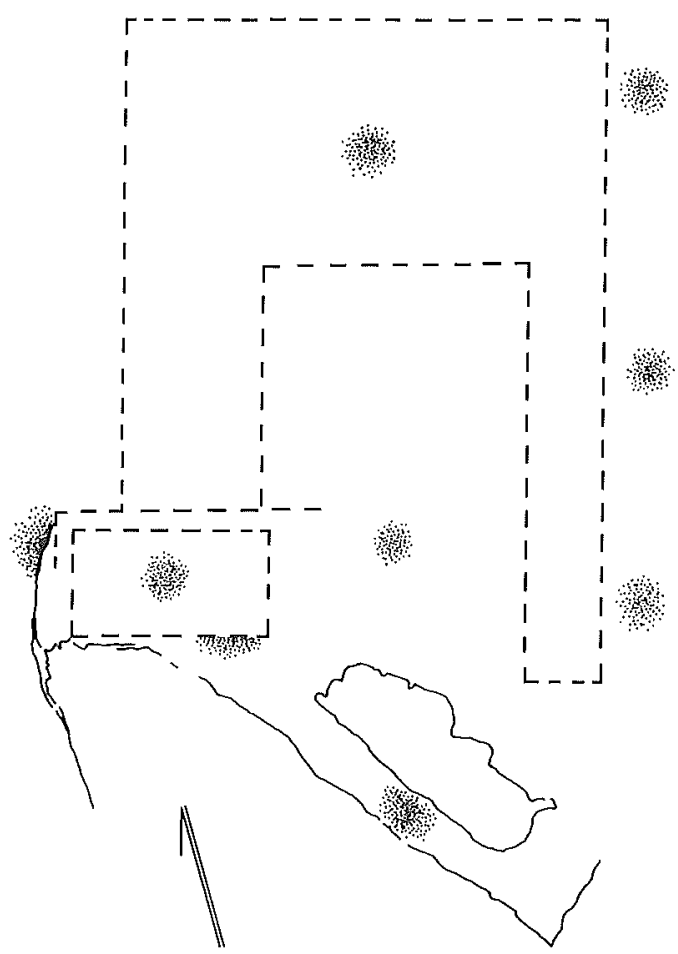

Fig. 6. Brauron, 8th-7th centuries BC.

The stippling indicates approximate areas where 8 th- and 7 th-century material has been recovered.

\section{Phase 1: The 8th -7th centuries BC (Fig. 6)}

The earliest evidence of post-Bronze-Age activity at Brauron consists of pottery recovered to the east of the stoa and reportedly going back to the 9th century or the late PG period. ${ }^{211}$ This material may very well derive from some kind of cultic activity in the area, the nature of which cannot be further defined, since the finds do not seem to be connected with any kind of architecture and the material was most likely not even found in situ, ${ }^{212}$ In the 8th century, the use of the site was intensified and the rise of an important

211 Themelis (1974), o.c. (n. 49), p. 10; Eustratiou, /.c. (n. 87), p. 79. The material was recovered from deep layers during the building of a pump-house. On the pre-historic activity in the area, see supra, n. 93.

212 Some 8th- and 7th-century material, including Corinthian lekythoi and aryballoi, has also been found east of the eastern propylon of the stoa, probably brought there by erosion from the 
sanctuary can be observed, already having particular areas accommodating the various functions needed. The basic structural organization which the sanctuary was to keep throughout its life span was established already at this stage, centring on the spring, the temple site, the area to the east of the temple and the cave.

The spring to the north-west of the temple may have been the feature which attracted the worshippers to the site in the first place. It certainly constituted an important cultic spot as early as the 8th century, as well as being the main area for the deposition of offerings. Pottery and other kinds of material found at this site date back to before $700 \mathrm{BC}$ but occur in abundant quantities in the 7th century. ${ }^{213}$ The question whether in this period this area was already connected with some architectural feature, such as a terrace, is difficult to answer. The material was found at the foot of the bedrock on top of which the later temple was constructed and it is possible that the votives were deposited by worshippers standing on the rock.

Some kind of shrine or simple structure is likely to have existed at this clate, housing a cult statue or statues, as well as dedications, perhaps those of a more valuable kind, in particular. ${ }^{214}$ The most probable location for such a building is the site where the later temple was built. ${ }^{215}$ In the open space to the east of the temple site, 7 th-century pottery and figurines were recovered, deriving from what seems to have been the site of the altar. $^{216}$ Sacrifices are likely to have taken place here and probably also dining, perhaps under temporary shelters or tents. The open area to the east and north, stretching towards the Erasinos, provided additional space for the diners, as well as easy access to the water of the river, and may have been used as a Festwiese. ${ }^{217}$

Erasinos river; see Ergon 1961, p. 28-29. Pottery of the 8th century was also recovered from deeper levels under the central section of the stoa; see Ergon 1960, p. 23. On the Kapsala hill, to the southeast of the sanctuary, Geometric tombs were excavated and a settlement of this period is likely to have been located somewhere in the vicinity; see PAAH 1957, p. 45; Ergon 1957, p. 23.

213 For the material recovered in this area, see above, p. 79-81.

214 The cult statue is likely to have been old, judging from the literary tradition. See also the later inscriptions mentioning the "old statue"; cf. Linders, o.c. (n. 8), p. 14-15; Romano, l.c. (n. 151), p. 130, n. 23 and 131, n. 43 . A clump of votive material next to the southern foundations of the later temple contained 8th-and 7th-century pottery and small metal objects, the oldest material dating to $c .775-750$, but the bulk being c. 750-700; see KAHL, 1.c. (n. 49), p. 232 and figs. 15.1 \& 15.2; $P A A H$ 1945-48, p. 86; PAAH 1949, p. 79 and figs. 7-8; PAAH 1955, p. 118.

215 Here, 8th- and 7th-century material was recovered, as well as traces of a paving and a transversal wall, interpreted by Papadimitriou as the remains of an earlier temple or an altar; see $P A A H$ 1955, p. 118. It has been suggested that already in the 8 th century a small, wooden chapel may have existed on the rock-cut terrace to the south of the temple; see Eustratiou, l.c. (n. 87), p. 79; A. Mazarakis Ainian, From ruler's' dwellings to temples: Arcbilecture, religion and society in. Early Iron Age Greece (1100-700 BC), Jonsered, 1997 (SIMA, 121), p. 317. This seems unlikely for various reasons. No pottery of this early date has been recovered here, but this may be due to the exposed nature of the site. On the other hand, a structure on this terrace presupposes that the terrace was already levelled in the 8th century. Such a major undertaking seems implausible at this date, considering the still modest size of the sanctuary, and should more likely be ascribed to a later phase when the building activity at Brauron was more substantial.

${ }^{216}$ PAAH 1956, p. $73-75$; PAAH 1959, p. 20; Ergon 1956, p. 25; Ergon 1959, p. 19-20. The area to the east of the temple has been heavily disturbed by later activity in the sanctuary, mainly in the Christian period.

${ }^{217}$ Hundreds of simple pottery mugs, dating from Sub-Geometric to later times but mainly from the early Archaic period, were found in a small area in the field to the east of the stoa, as if they had been thrown together there after local use, presumably at meals, see Th. HaDzisteliouPrICE, Kourotrophos: Cults and representations of the Greek muring deities, Leiden, 1978 (Studies of the Dutch Archaeological and Historical Society, 8), p. 122 with n. 113 and p. 207. On the Festwiesen as important components of Greek sanctuaries, see U. SINN, "Sunion. Das befestigte 
While the majority of the worshippers dined out in the open at the festivals, the religious office-holders and other prominent participants could have taken their meals in the cave, enjoying its seclusion and shade. The cave may also have been used as accommodation for the priestesses or other officials staying at the sanctuary for long periods. If the number of girls performing the arkteia at Brauron was very limited, as was argued above (see p. 91-92), the cave was perhaps used as living quarters for these arktoi. ${ }^{218}$ The material recovered from the cave suggested that it had a second function as well, namely as a storage space for dedications, perhaps supplementing the temple in this respect.

\section{Pbase 2: The 6th century down to the first balf of the 5th century BC (Figs. 7-8)}

The second phase of the sanctuary witnessed a great surge of building activity, resulting in the elaboration of the areas used in the previous period, as well as the erection of new buildings to accommodate certain functions that were in need of more space. $^{219}$

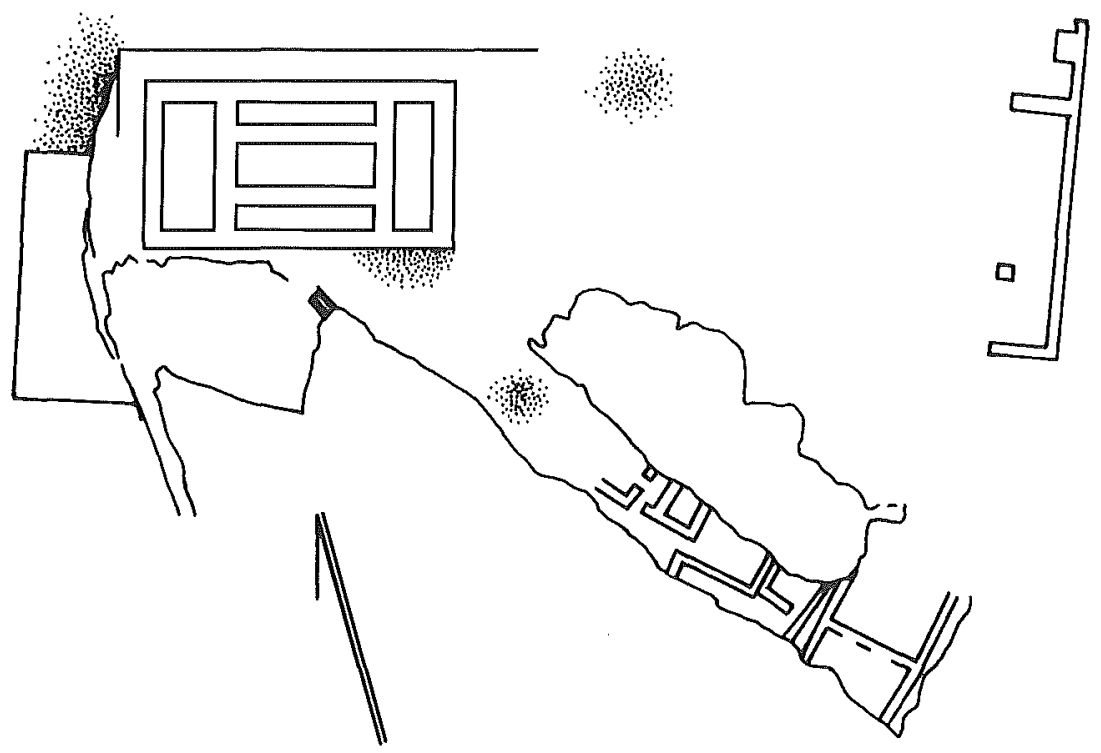

Fig. 7. Brauron, 6th century BC. The stippling indicates approximate areas where 6th-century material not directly associated with any architecture has been recovered.

Heiligtum der Athena und des Poseidon an der 'Heiligen Landspitze Attikas'”, AW 23 (1992), p. 183, figs. 11 and 13-14.

218 The link between caves and bears has been stressed by Paula PerLan ("Acting the she-bear for Artemis", Aretbusa 22 [1989], p. 122-124), who proposed that the cave at Braturon was connected with the festival of the arkioi, by analogy with how the she-bear withdraws into a cave to hibernate, give birth to the cubs and later re-appear as a mother. It is not known when the arkteia was introduced at Brauron. On the ritual being old, see above, n. 40.

219 This flourishing has been connected with Peisistratos originating from Brauron, see PHOT., s.v., B povpovía (Theodoridis, B 264); S. Angrolillo, "Pisistrato e Artemide Brauronia", PP 38 (1983), p. 351-354; Peppas-Delmousou, l.c. (n. 7), p. 323-329. On Peisistrastos and the cult of Artemis Brauronia on the Acropolis, see below, n. 260. 
The Archaic period saw the construction of the first stone temple, dated to the end of the 6 th or the beginning of the 5th century $\mathrm{BC}^{220}$ Only a few traces of this temple have been preserved, but it is likely that it was Doric and had an inner arrangement similar to that of the later, Classical temple, i.e. an inner room at the back and a cella with two rows of columns between which the cult statues were presumably placed. ${ }^{221}$ The erection of a stone temple must have called for the expansion on a substantial scale of its immediate surroundings. The present terrace wall to the north of the temple, rising five steps to a total height of $1.5 \mathrm{~m}$, probably belongs to the late 6th century, covering any possible predecessor. ${ }^{222}$

A further reason for extending the temple area may have been the intensification of the votive practices and dedications of offerings made by the worshippers, apparent from the particularly rich and abundant material dating from this period and found at the spring. ${ }^{223}$ The great terrace to the west of the temple is also likely to have been constructed in this period. ${ }^{224}$ Though the purpose of this structure is unclear, it may also to be connected with the dedication of offerings. The terrace may have functioned as a platform on which dedications were displayed or on which the worshippers may have stood when depositing votives in the spring or it may have constituted the foundation for a stoa in which dedications were housed. ${ }^{225}$ The inner room of the temple was probably also used for the storing of votives, while larger dedications, such as reliefs and sculptures, were placed on top of the terrace wall to the north. ${ }^{226}$

220 Ergon 1955, p. 33; cf. PAAHI 1945-48, p. 86; PAAH 1949, p. $75-76$ and 89-90, fig. 20; cf. BOERSMA, o.c. (n. 135), p. 35 and 176 , no. 42. The paving and the transversal wall discovered under the later cella may belong to the early part of this phase. Pottery of 6th-century date was recovered in the area of the cella and 6th-and 5th-century sherds and terracotta figurines also came from the dump along the southern side of the foundations for the temple.

221 The remains of the Archaic temple consist of a few architectural parts and cuttings in the rock; see PAAH 1945-48, p. 86; PAAH 1949, p. 75-76; Ergon 1955, p. 33. On the cult statues, their age and numbers, see Linders, o.c. (n. 8), p. 14-15; Romano, l.c. (n. 151), p. 131-132, esp. n. 43; Tréheux, l.c. (n. 151), p. 1-6.

222 PAAII 1945-48, p. 84; PAAH 1949, p. 77. Indications of the date of this terrace consist of a deposit of ashy soil mixed with pottery of early-5th-century date discovered along the western section of the northern side of the terrace. On top of this layer, a row of stele bases was placed in the late 5 th or early 4 th century.

223 See above, p. 79-82. Some of the 5th-century material had been transported further north by the flow of water from the spring and was found embedded in the mud; see Ergon 1962, p. 27-28 and figs. 33-35.

${ }^{224}$ PAAH 1949, p. 77-79, fig. 6; PAAH 1956, p. 75; PAAH 1959, p. 19; TheMELIs, l.c. (n. 7), fig. 2, no. 4; 5th-century material is reported from on top of this structure. At the south-western corner of the terrace, a staircase leads up to the level of the temple (see PAAH 1956, p. 74, fig. 1).

225 It is not clear whether the whole terrace was level with the top of the rock where the temple is situated. Perhaps the terrace consisted of several steps or levels from which worshippers may have watched the activities at the spring or where votives were displayed. What looks like a block from an exedra is visible at the northern end of the terrace; see $P A A H 1956$, p. 75 , fig. 1 . To the north-west of the western terrace was found a paving and an enclosure forming a sacred lake (Ergon 1961, p. 30-31). These two features are probably to be connected with the Archaic phase of the sanctuary, when the increased votive activity at the spring may have called for more permanent arrangements than just the bare, living rock.

${ }^{226}$ On the adyton and possible material deriving from it, see above, p. 80-82. Fragments of a cylindrical altar bearing a relief of Dionysos and a number of other divinities may have stood on top of the northern terrace wall (see supra, n. 71). 


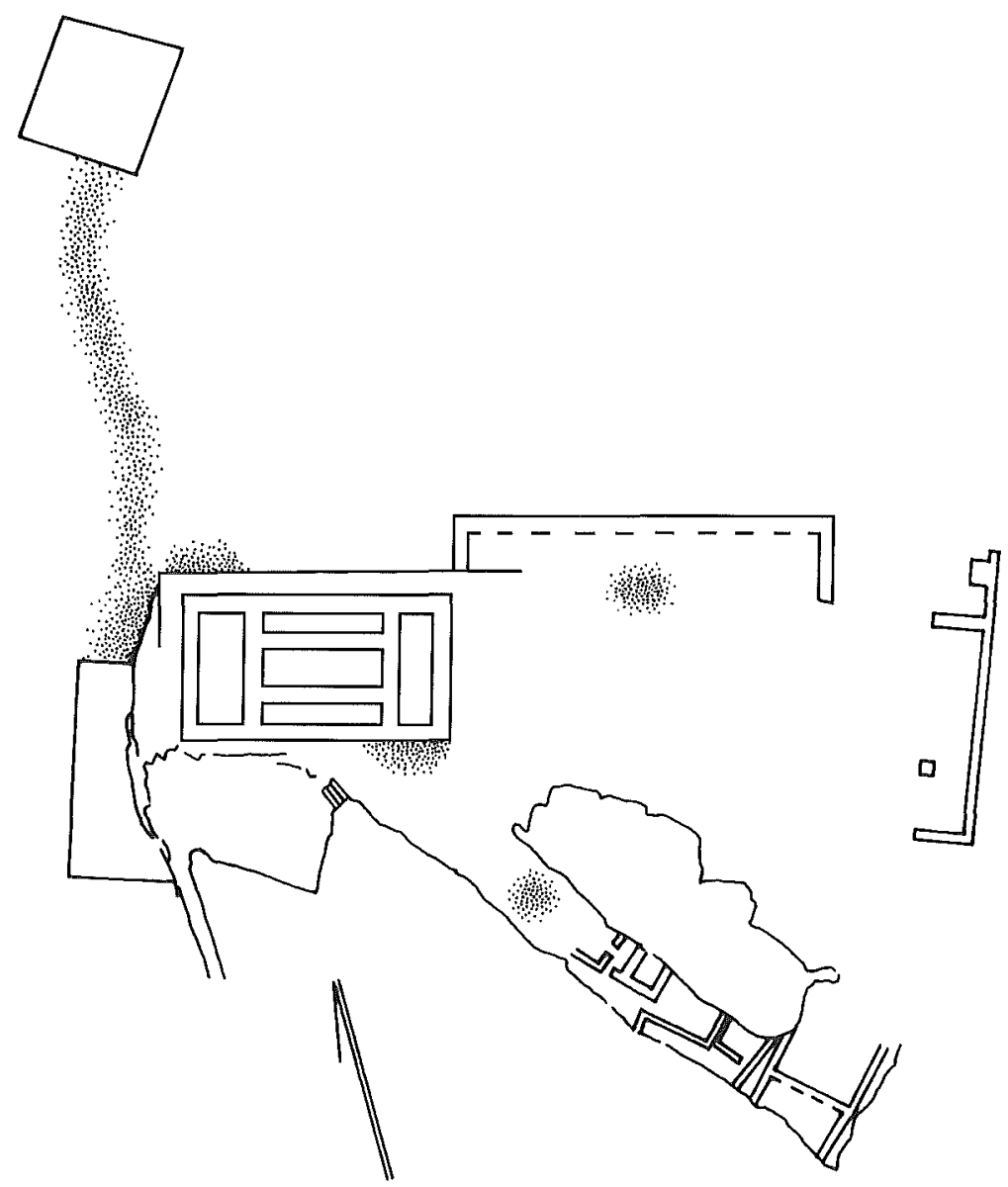

Fig. 8. Brauron, first half of the 5 th century $B C$. The stippling indicates approximate areas where 5th-century material not directly associated with any architecture has been recovered.

To this phase may also be assigned the creation of the terrace or platform cut out of the bedrock to the south of the temple, where the 15th-century-AD church of Ag. Georgios stands today. The principal argument for dating the execution of this terrace to the Archaic period and not earlier is the fact that this was a major undertaking more compatible with the monumentalization of the sanctuary in this period than the more modest activities of the previous centuries. The rock-cut platform is accessible from the lower-lying temple by five steps carved out of the cliff in the north-eastern corner. No finds are reported from the terrace itself, but the face of the rock on the higher levels at its eastern and southern sides shows a number of cuttings for votives and stelai, while, inside the church, cuttings for some kind of structure are also visible. ${ }^{227}$ Considering the laborious work involved in creating this terrace and its closeness to the main temple, it is likely to have housed some kind of structure or installation central to the cult, such as an altar or a small shrine. ${ }^{228}$

227 PAAH 1945-48, p. 86; Papadinitriou, l.c. (n. 4), p. 113.

228 Papadimitriou (l.c. [n. 4], p. 113) suggests an altar; Kondis (l.c. [n. 3], p. 168-169) the main altar of Artemis. That the main altar would have been located here seems unlikely, however. First 
The monumentalization of the sanctuary in this period is also visible to the east of the temple, where the altar was probably located. ${ }^{229}$ Here, a terrace of polygonal poros blocks topped with cut limestone blocks was constructed, running from west to east, with a north-south extension at each end (Fig. 8). ${ }^{230}$ The fill within this wall contained 6th-and 5th-century pottery, terracotta figurines, two black-figure, terracotta dice, some fragments of sculpture and some fragments of gold, parts of an early-5th-century inscription, as well as ash. It is clear that the wall supported only a terrace and not a building, such as a stoa, and that its purpose was probably to extend and formalize the altar area. ${ }^{231}$ The terrace may have been used for the display of votives but also provided space for the worshippers to observe and participate in the sacrifices and the rituals. An important element of the arkteia, which is depicted on the 6th" and 5th-century krateriskoi, seems to have been races for the arktoi, running around or to the altar, perhaps in connection with the shedding of the krokotos. ${ }^{232}$ The construction of the terrace may have provided more room for this particular ritual.

The importance of the altar area is underlined by the construction of a building further to the east, formalizing the extension of the sanctuary in that direction. ${ }^{233}$ This building, constructed of poros blocks, was at least $20 \mathrm{~m}$ long. Since the structure was partly obliterated by the construction of the later stoa, its layout is not clear, but it seems to have been divided into rooms or sections, the northernmost one perhaps functioning as a propylon. ${ }^{234}$ The southern section was $c .15 \mathrm{~m}$ long and may have been a stoa facing

of all, the altar area to the east of the temple shows activity already in the 7th century (see above, n. 216). Secondly, an important feature of the arkteia seems to have been a race to and around the altar, a motif which is depicted on the krateriskol; see KaHIL (1965), l.c. (n. 6), p. 20-33; Ead. (1977), l.c. (n. 6), p. 88; Ead., I.c. (n. 22), p. 804-805; Themelis (1974), o.c. (n. 49), p. 16. This ritual must have been hard to perform, if the altar had been located at this elevated and off-centre position. Thenelis (l.c. [n. 7], p. 231) proposes that the older temple of Artemis was located here (which leaves the early pottery and traces of walls under the main temple unexplained). On the presence of an earlier shrine here, see also supra, n. 215.

229 It has been suggested that the altar is shown on a fragment of a late, black-figure krateriskos; see KaHL (1977), l.c. (n. 6), p. 87 and pl. 21:1; Ead., l.c. (n. 22), p. 806. On this sherd, to the right of the depicted altar, are two columns which may represent the temple, since the stoa with its colonnade had not yet been constructed when this vessel was manufactured.

${ }^{230}$ PAAH 1959, p. 20; Ergon 1959, p. $19-20$ and fig. 20; Bouras, o.c. (n. 5), p. 9-13; Boersma, o.c. (n. 135), p. 35 and 160 , no. 17. At the western end, the north-south extension of the polygonal terrace wall abuts on the temple terrace and can therefore be dated to $c .500-450 \mathrm{BC}$. Further to the south were found the remains of a paving and a wall, as well as 6th-and 5th-century pottery and terracotta figurines and ash; see PAAH 1956, p. 75 and pl. 18 b; Ergon 1956, p. 25. This material may perhaps represent an earlier extension of the altar area.

231 Bouras, o.c. (n. 5), p. 9-13. On the remains being those of a stoa, see Lauter, o.c. (n. 156), p. 44 .

232 Sourvinou-Inwood (1988), o.c. (n. 17), p. 39-64; Kahil (1965), l.c. (n. 6), p. 20-33; Themelis (1974), o.c. (n. 49), p. 16.

233 Ergon 1962, p. 29-32; cf. Ergon 1961, p. 21; Ergon 1962, p. 28-29; THemelis, l.c. (n. 7), p. 239, fig. 1, no. 4 .

234 Ergon 1962 , p. 29-30. A poros paving with wheel ruts was found to the north. The suggestion that the northern section was a propylon is not entirely convincing, since the visitors entering here would immediately have stumbled on the terrace supporting the altar area (see my Figs, 1 and 8). It is more likely that the entrance from the east was situated further to the south, between the eastem building and the acropolis. Furthermore, if this building partly functioned as a propylon, it is strange that this function could be completely erased in the late 5th century, when the back wall of the eastern wing of the new stoa was constructed (see further below, p. 108-109). The wheel ruts may perhaps derive from the period when the sanctuary had been abandoned. 
west or a larger room with internal supports. ${ }^{235}$ The finds included rich find material (see above, p. 81-82, and Table 2) but also ash. Owing to the similarity of the material recovered here to the finds from the spring and the cave, the eastern building may have been used for the storage and display of offerings. Its location facing the altar area, however, is also important. The building may have been used as a dining-room for the meals following the sacrifices and, if it had a colonnade facing west, worshippers could have watched the rituals taking place at the altar from here. ${ }^{236}$ An increase in the number of visitors and worshippers may have called for the construction of this building. The open field to the north of the polygonal terrace and the altar area was presumably still used for dining and a more extensive use of this area may have called for more elaborate arrangements for dealing with the water flow from the spring and the Erasinos, such as the construction of a flat, poros bridge to the west in the mid-5th century (Fig. 8), ${ }^{237}$

Ritual meals and storage of offerings may also have been the two main functions of the cave area in this period. There is abundant, 6th- and 5th-century material which can be connected with the rooms $\mathrm{A}, \mathrm{B}, \Gamma, \Delta$ and $\mathrm{E}$, stretching the whole length of the cave (Fig. 2). ${ }^{238}$ The layout of the structures within the cave seems to have undergone certain changes, presumably in this period, and it was suggested above that the area was now principally used for the keeping of dedications, although a function as a dining-room or perhaps living quarters may be proposed for one of the rooms. This change in use can be connected with the erection of the building to the south-east of the cave, the so-called "Sacred House", which could have been used as a dining-room, accommodating eleven klinai (Fig. 3, no. 2). ${ }^{239}$ If this interpretation of its function is correct, dining for some worshippers and religious office-holders, which previously took place within the cave, could in this period have been moved to the "Sacred House".

At the end of this phase, the sanctuary was equipped with a stone temple, storage space for votive offerings in the inner room of the temple, the eastern building and the cave, and formal dining facilities in the "Sacred House" and the eastern building. The cave may still, though to a lesser extent, have been used for ritual meals or perhaps for the accommodation of the religious office-holders or the selected arktoi. This second phase in the history of the sanctuary was terminated by two events, the sack by the Persians in 480 $\mathrm{BC}$ and the destruction of the temple, and the collapse of the roof of the cave, probably around $450 \mathrm{BC}^{240}$

\section{Phase 3: The second balf of the 5th century to the late 4th century BC (Fig. 9)}

The greatest undertaking of the third phase was the construction of the large, pishaped stoa to the north, framing and extending the area in front of the temple on its

235 See Ergon 1962, p. 29, fig. 36; one internal support was excavated to the south. A large, battered, Doric poros capital incorporated in the eastern wall of the 5 th-century stoa may have originated from the front or inner colonnade of this building (see Ergon 1961, p. 21).

${ }^{236}$ On stoas being used for these kinds of activities, see G. KuHN, "Untersuchungen zur Funktion der Säulenhalle in archaischer und klassischer Zeit", JDAI 100 (1985), p. 169-317. THEMELIS (l.c. [n. 7], p. 239, fig. 1) reconstructs the building as one large room with four internal supports and suggests a function as a dining-hall. For Archaic, broad-room bestiatoria of a similar shape and proportions, see Bergquist, l.c. (n. 130), p. 29-36.

237 Ergon 1961, p. 29-30; Ergon 1962, p. 25-27; Boersma, o.c. (n. 135), p. 62 and 225, no. 107. Two walls, probably of Classical date, since they incorporate parts of the Archaic temple, were also built between the western terrace and the site of the later stoa to prevent flooding of this part of the sanctuary.

238 For the evidence, see above, p. 74-80.

239 See above, p. 85.

${ }^{240}$ For a different chronological scenario at the cave, see above, p. 86-87. 
western, northern and eastern sides. ${ }^{241}$ The construction of the stoa meant the desertion and levelling of the eastern building, but its functions seem to have been transferred to the new stoa. The stoa seems to have been meant to have a colonnade on all three sides, but only the northern one was completed (Fig. 5). A formal entrance was located in the western wing. On the western and northern sides, the building had a series of rooms equipped with couches and tables and thus functioning as dining-rooms. ${ }^{242}$

The stoa can, on stylistic grounds, be dated to around $420 \mathrm{BC}$, a date confirmed by the finding in the eastern wing of an inscription from the year of the archon Arimnestos in $416 / 15 .{ }^{243}$ The main function of the building must have been to serve as a dining facility but from the colonnade the worshippers could also have watched the sacrifices and other rituals taking place in the open area at or near the altar. ${ }^{244}$ The northern colonnade was also used for the display of prestigious votive offerings and here were found several high quality reliefs (including the so-called "Relief of the gods"), fragments of more than 50 statues of arkto $i$, statues of small boys, fragments of two Panathenaic amphorai and a great number of bases for various kinds of objects. ${ }^{245}$ In the centre of the northern wing, a narrow passage led to the courtyard with the shallow stoa with its row of stele bases, suggested above to have housed wooden boards bearing the names of all the girls eligible for the arkteia during a certain period of time.

In the 5 th century, some time after 480 , a new stone temple was erected, probably with the same plan as its predecessor and replacing the building destroyed by the Persians. ${ }^{246}$

241 Bouras, o.c. (n. 5), passim; PAAH 1949, p. 83-84; PAAH 1950, p. 177-187; PAAH 1959, p. 18-19; Ergon 1958, p. 31-39; Ergon 1959, p. 13-15; Ergon 1960, p. 21-26; Ergon 1961, p. 21-29; Ergon 1962, p. 37-39; M.S. Goldsters, The selting of the ritual meal in Greek sanctuaries: 600-300 BC, Ph.D. Diss., University of California, Berkeley, 1978, p. 114-125; Börker, l.c. (n. 5), p. 802-806; Covlton, o.c. (n. 146), p. 42-43 and 226-227; Boersma, o.c. (n. 135), p. 91, 95 and 214, no. 90.

242 The traces of hearths or fires found in the centres of several of the rooms, suggested by Bouras (o.c. [n. 5], p. 78 and 170) to be signs of later re-use of the abandoned building by shepherds, may just as well be taken as indications of the rooms being used for ritual meals. An optaion tile (Id., o.c. [n. 5], p. 79, fig. 58) may also have belonged to this building and was perhaps used for letting the smoke out.

243 Bouras, o.c. (n. 5), p. 149-159; PAAH 1959, p. 18; Ergon 1958, p. 37; Eigon 1959, p. 13; BoERSMA, o.c. (n. 135), p. 91, 130-131, no. XIII, and 214, no. 90. For the pottery from the stoa, see KaHIL (1963), l.c. (n. 6), p. 27. Nine of the rooms of the stoa have the same square plan and proportions, housing eleven couches and seven tables. Two smaller rooms, located at the southern end of the western wing and entered from the east and at the western end of the northern wing and entered from the open courtyard to the north, have been explained as rooms for the guards (Ergon 1961, p. 26), a dining-room and a storage facility for valuable offerings, respectively (Travlos, o.c. [n. 3], p. 55) or as housing wooden staircases for a presumed upper floor (Mylonopoulos \& Bubenheimer, l.c. [n. 50], p. 18).

244 On the use of stoa for such purposes, see KuHN, l.c. (n. 236), p. 169-317, esp. 259-260 for Brauron.

245 Bouras, o.C. (n. 5), p. 141-148; Ergon 1958, p. 35-38, figs. 35-37; Ergon 1960, p. 22-23, figs. 30 and 32.

246 Papadimitriou dated the temple to the first half of the 5 th century BC (see Ergon 1959, p. 1920); cf. PAAH 1945-48, p. 86-89 and PAAH 1949, p. 75. Other dates have also been proposed, see Boersma, o.c. (n. 135), p. 51 and 175, no. 42 (c. 500-450 BC); Hollinshead, l.c. (n. 9), p. 432 with n. 63 (c. 475-450 BC); Travlos, o.c. (n. 3), p. 55 (early 5th century); Mylonopoulos \& Bubenheimer, l.c. (n. 50), p. 12-14 (c. 425-400). A deposit of votives found near the southern foundations of the temple must have been laid down after its construction, since the deposit contained material from the 8 th to the 4th century $\mathrm{BC}$ (the latest material being hand-made, terracotta figurines); see $P A A H$ 1949, p. 79 and 90. There are only scanty remains of the Classical temple. John Camp, at a lecture given in Athens in 1991, suggested that this temple, or parts of it, may have been moved to Athens in the Augustan period. For such "wandering" temples and monuments, see H.A. THOMpson \& R.E. 
Apart from this construction, the area around the temple seems to have undergone few changes. Even though the spring area has yielded predominantly pre-Persian material, there is also a fair number of late-5th-century finds, showing that this part of the sanctuary was still of interest in this period. ${ }^{247}$ Here were also found several fragments of reliefs, sculptures and inscriptions, some of which may originally have been placed along or on top of the northern temple terrace. ${ }^{248}$ To the south of the western terrace was found a rich deposit of 5th-century material (including high-quality, terracotta figurines and red-figure pottery) which the excavator suggested had derived from a small shrine higher up, perhaps located on the rock-cut terrace where the small church stands today. ${ }^{249}$

The cave area was apparently abandoned in the mid-5th century, presumably after the collapse of the roof of the cave, which led to the rooms within all being covered by stones. The "Small Temple", erected at the north-western entrance of the cave, may have taken over some of the functions of the now deserted structures inside the cave (Fig. 3, no. 1). ${ }^{250}$ Owing to the size of this building and the spot of ash found in its centre, it was suggested above that the "Small Temple" may have been used as a bestiatorion, perhaps for a select group of diners distinct from those dining in the stoa to the north. It is also possible that the "Sacred House", to the south-east of the cave, was no longer in use in this period and the ritual meals suggested to have taken place there were now staged in the "Small Temple". 251 The storage of votives, which previously may have been the main function of the cave, was probably transferred to the temple and, in particular, to its inner room. ${ }^{252}$

If the religious office-holders or the arktoi also used the rooms in the cave when staying at the sanctuary, they must now have been accommodated elsewhere. The excavator suggested that the arktoi in fact lived in the rooms with the couches in the stoa, an interpretation which has few adherents today. ${ }^{253}$ If the stoa had a second floor, which is disputed, the arktoi, as well as the religious office-holders, may have been housed there. ${ }^{25 i}$ Another possible candidate is a small building with two rooms, probably of

Wycherley, The Athenian Agora XIV. The Agora of Atbens: The bistory, sbape and uses of an ancient city centre, princeton, 1972, p. 160-168; W.B. Dinsmoor, Jr., "Anchoring two floating temples", Hesperia 51 (1982), p. 411-452.

247 PAAH 1959, p. 19; Ergon 1959, p. 15-16.

248 For example, marble heads of arktoi (PAAH 1950, p. 177, figs. 6-11; PAAH 1959, pl. 12 b-d) and a late-5th-century relief showing Artemis and a goat with three kids (Ergon 1959, p. 17, pl. 18).

249 PAAH 1959, p. 19; Ergon 1959, p. 15 and figs. 12-14.

250 For the evidence, see above, p. 85-86.

251 For the "Sacred House", see above, p. 85. Only 6th- and 5th-century material is reported from this building. The diners may, of course, also have been moved to the new stoa.

252 On the temple being used for the storage of the dedications mentioned in the 4th-century inventories, see Linders, o.c. (n. 8), p. 71-72. Possibly the small room at the south end of the western wing of the stoa closest to the temple (see supra, n. 243) was also used for the keeping of votives.

253 PAAH 1958, p. 36-37; Papadimitriou, l.c. (n. 4), p. 118-119. On the rooms being hestiatoria, see BörKer, l.c. (n. 5), p. 805-806, and Goldstein, o.c. (n. 241), p. 114-125.

${ }^{254}$ No architectural members of a second floor have been recovered. Mrlonopoulos \& Bubenheimer (l.c. [n. 50], p. 18) suggest that the two small rooms at the southern end of the east wing and the eastern end of the north wing respectively may have housed wooden staircases to the upper floor and that the lack of blocks from this storey is simply due to the site being plundered in later periods. 
Classical date, excavated to the east of the sanctuary, on the slope of the acropolis. ${ }^{255}$ Among the pottery recovered within were krateriskoi of the kind typical of the arkteia. ${ }^{256}$

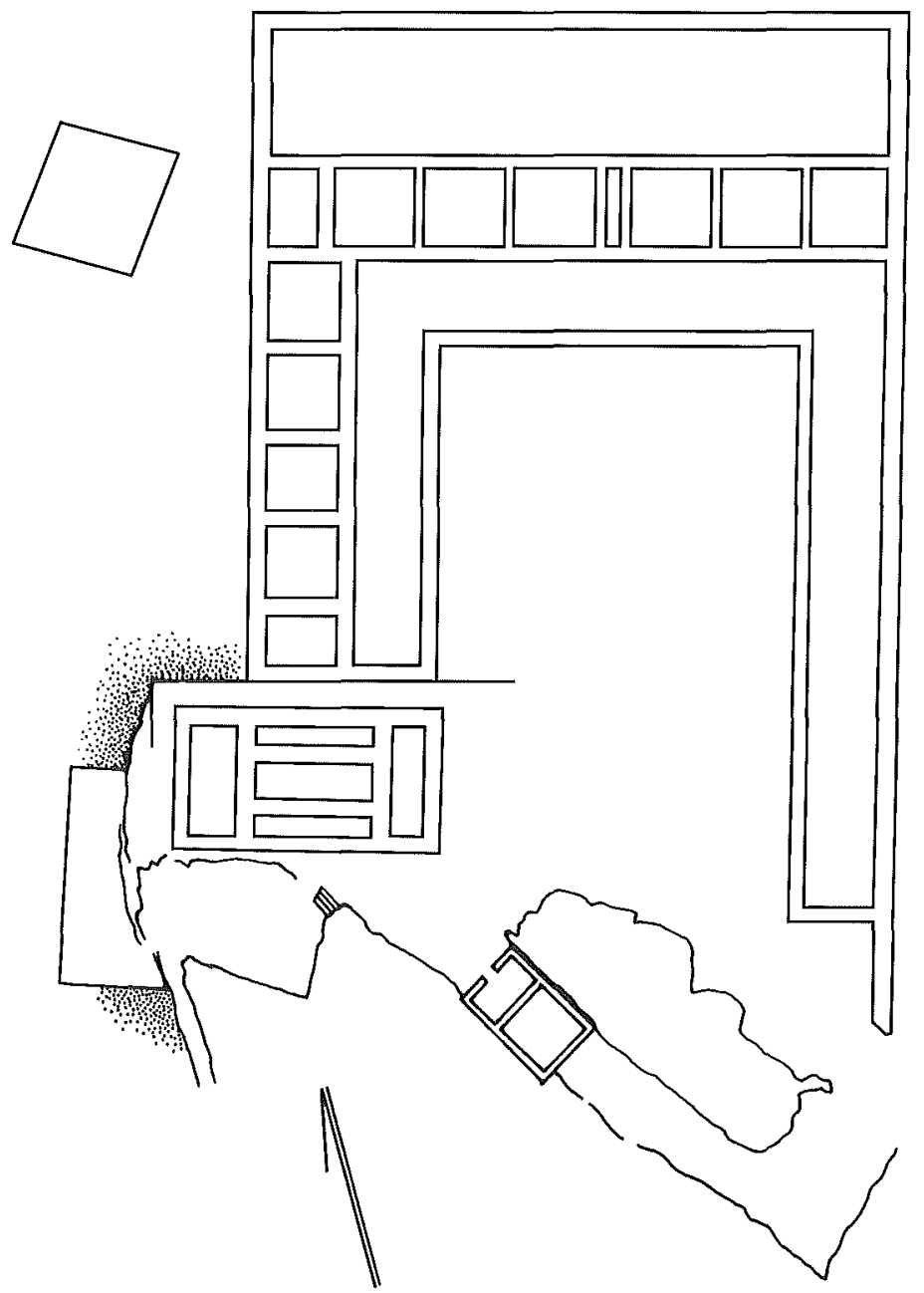

Fig. 9. Brauron, second half of the 5 th century BC to the late 4 th century $\mathrm{BC}$. The stippling indicates approximate areas where late-5th- to late-4th-century material not directly associated with any architecture has been recovered.

255 Ergon 1961, p. 35-36, fig. 40. The interior of the building was $3.25 \mathrm{~m}$ wide and was excavated to an interior length of $5.14 \mathrm{~m}$.

256 Ergon 1961, p. 36, fig. 41. For the krateriskoi, see KAHIL (1963), l.c. (n. 6), p. 13-14, nos, 25-26, pl. 6:1-2, dating them to the first half of the 5th century BC; cf. Ead. (1965), I.c. (n. 6), p. 20-22, nos. 2-3, pl. 7:3 and 5. A large number of krateriskol were also recovered in the cave area. At the recent excavations at Halai, c. $200 \mathrm{~m}$ to the south of the temple, was discovered a small building with an interior hearth and among the finds were a number of krateriskoi; see Eustratrou, l.c. (n. 35), p. 73; Kahil (1977), l.c. (n. 6), p. 88 with n. 23 and 96; Brulé, o.c. (n. 9), p. 193. Perhaps this building may have had a similar function to that of the structure found at Brauron. 
To sum up, the importance of Brauron during the second half of the 5 th century, as well as during the 4th century, is clear from the building activity, but also from the reliefs and sculptures dedicated and from the epigraphical material. ${ }^{257}$ This was an important rural sanctuary of interest to the Athenian state, not just the local deme Philaïdai. ${ }^{258}$ Those of the women dedicating clothes in the sanctuary who are identified by family and demotic names did not for the most part come from the local deme or the neighbouring demes, but from quite far away. ${ }^{259}$ Brauron was also one of the few Attic sanctuaries, if not the only one, outside Athens to have a branch inside the city, in this case even on the Acropolis itself, and a procession apparently took place from this precinct of Artemis Brauronia to the sanctuary at Brauron. ${ }^{260}$

In this period, the sanctuary at Brauron must be expected to have catered for various religious needs: to house the religious office-holders and the selected arktoi for long periods of time, to accommodate larger numbers of visitors more temporarily in connection with the Brauronia and other festivals, to receive private visitors making dedications, as well as the storing of a great number of offerings of various kinds, such as clothes, jewellery, pottery, sculptures and reliefs. The dedication of votives, such as clothes and sculptures of children, may have taken place at any time during the year and not necessarily in connection with a particular festival. ${ }^{261}$ The extensive use of the sanctuary on the private level is perhaps best illustrated by the fact that the majority of the child statues are boys. ${ }^{262}$ The dedication of statues of girls can be seen as having been engendered by the arkteia but, as no corresponding festival for boys is known, these dedications must have been made on a private basis to Artemis as a protector of families, mothers and their offspring. ${ }^{263}$

257 Most of the arktoi heads and sculptures seem to be 4 th century; see, for example, Papadimitriou, l.c. (n. 4), p. 116; cf.J. Frel, "Deux têtes d"arktoi' et deux rectifications supplémentaires", Bulletin du Musée Hongrois des Beaux-arts 24 (1964), p. 3-4, and S. PAPASPYRIDI-

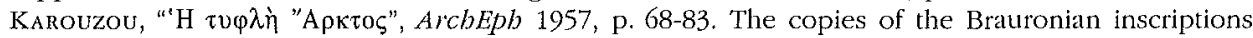
found in Athens date to the mid-4th century; see Linders, o.c. (n. 8), p. 5. For some of the exceptional lebetes gamikoi from the mid-4th century, see L. KAHIL, "Quelques examples de vases de mariage à Brauron", in Petrakos, o.c. (n. 69), p. 379-404.

258 The absence of any deme records also shows that the sanctuary was administered by the state rather than by the deme; see OsBorne, o.c. (n. 2), p. 170. On Brauron not being made into an independent deme and perhaps being omitted from the Cleisthenic system, since it was the home town of Peisistratos, see Whitehead, o.c. (n. 2), p. 11, n. 30, 24, n. 83 and 177, n. 6. The remains of the deme-centre of Philaîdai have been tentatively identified c. $1.5 \mathrm{~km}$ to the east of the sanctuary; see Osbonne, o.c. (n. 2), p. 193, s.v., Philaïdai and pl. 12.

259 For the prosopography, see OsBorne, o.c. (n. 2), p. 158-160; Antoniou, o.c. (n. 7), p. 79-124.

260 The Athenian Brauronion was perhaps founded by Peisistratos, stemming from Brauron; see Kahil, l.c. (n. 34), p. 253-263; Anglolillo, l.c. (n. 219), p. 351-354; Peppas-Delmousou, l.c. (n. 7), p. 323-329; Boersma, o.c. (n. 135), p. 15; cf. Рhot., s.v. B $\alpha \alpha v \rho \omega v i \alpha$ (Theodoridis, B 264). On the Athenian Brauronion, see J.M. Hurwit, The Atbenian Acropolis, Cambridge, 1999, p. 197-198; R.F. Rhodes \& J.J. Dobrins, "The sanctuary of Artemis Brauronia on the Athenian Acropolis", Hesperia 48 (1979), p. 325-341; Osborne, o.c. (n. 2), p. 154-156 and 172-173. The only comparable case is Eleusis and the Athenian Eleusinion located just east of the Panathenaic road on the outskirts of the Agora. For the procession, see Deubner, o.c. (n. 20), p. 208; Kondis, l.c. (n. 3), p. 184.

261 This is plausible, since the clothes seem to have been dedicated as thank-offerings after successful births. On rural Dionysia being performed at Brauron, see above, n. 71.

262 Kondis, l.c. (n. 3), p. 180 and 190; Cole, l.c. (n. 22), p. 238; Brulé, o.c. (n. 9), p. 24-25; cf. Th. Hadzisteliou-Price, "The type of the crouching child and the 'temple boys'", ABSA 64 (1969), p. 97. On the "male" presence at Brauron, see THemelis, l.c. (n. 7), p. 226-227.

263 BrulÉ (o.c. [n. 9], p. 259) suggests that male initiation ceremonies similar to those for the girls at Brauron may have been performed at nearby Halai. 
All this activity and, in particular, the construction of the stoa can be taken as signs of the cult flourishing and attracting greater interest. Euripides' tragedy Iphigeneia among the Taurians, which was probably produced around $413 \mathrm{BC}$, can also be seen as an indication of the importance of Brauron. This increase in the use of the sanctuary may have been the result of a general concern for the principal sanctuaries of Attica in the late 5 th century, a pattern which can be observed also elsewhere. ${ }^{264}$ In the particular case of Brauron, however, the performance of the arkteia, a ritual of concern for the whole polis, may also have contributed to the flourishing of the sanctuary.

\section{Phase 4: The 3rd century $B C$}

Very little is known of the sanctuary in the 3rd century and hardly any finds are reported from the area. The flourishing in the 4th century was probably followed by a period of decay, most likely due to political disturbances in Attica and by the flooding of parts of the sanctuary by the Erasinos. ${ }^{265}$ Some dedications of child sculpture were made and a small statue of Hekate also dates from this period. ${ }^{266}$ When the contemporary writer Euphorion speaks of Brauron as the cenotaph of Iphigeneia, he may therefore only be echoing Euripides rather than being inspired by a thriving sanctuary. ${ }^{267}$

The major source of information for this period is an Athenian state decree, issued by the nomothetai and dated to the 3rd century BC. This inscription was recovered in the western wing of the stoa. ${ }^{263}$ Here it is commanded that the buildings in the sanctuary at Brauron are to be inspected and put into order, the works to be paid for by the Athenian state. This wording indicates that a period of decay must have occurred, even though a complete desertion of the sanctuary and disintegration of the buildings do not have to be assumed. The restoration is in line with the general trend all over Attica in this period, when old, traditional, ancestral cults were being revitalized. ${ }^{269}$

The section of the inscription mentioning the buildings runs as follows: ${ }^{270}$

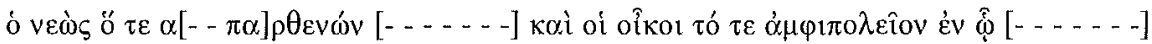

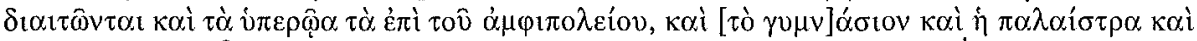

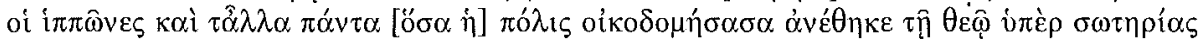

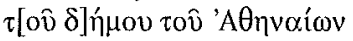

\footnotetext{
264 See Boersma, o.c. (n. 135), p. 91 .
}

265 The stoa was apparently in use for only a brief period of time and the excavator suggested that the building was partly flooded by the Erasinos in the late 4 th century and therefore deserted; see Papadimitriou, l.c. (n. 4), p. 120; PAAH 1959, p. 19; Ergon 1958, p. 38; Ergon 1959, p. 13; Bouras, o.c. (n. 5), p. 169.

266 3rd-century sculpture; see Kondis, l.c. (n. 3), p. 203; KaHIL (1984), l.c. (n. 6), nos. 140-361. For the Hekate, see supra, n. 70.

267 On Euphorion, see supra, p. 62. It is not clear whether he refers to the whole site of Brauron or only to a monument dedicated to Iphigeneia.

268 The inscription is known from a number of excerpts and there are slight variations in the suggested datings; see Ergon 1961, p. 24-25; PAPAdimitriou, 1.c. (n. 4), p. 120 (3rd century); SEG 35 (1985), no. 83; THemelis, l.c. (n. 7), p. 230-232 (3rd century); SEG 37 (1987), no. 89 (3rd century?); Peppas-Delmousou, l.c. (n. 7), p. 336-337, esp. n. 49 (3rd century); Antoniou, o.c. (n. 7), 280-281, no. 4 (middle of the 3rd century); Mylonopoulos \& Bubenhemmer, l.c. (n. 50), p. 8-9 with n. 14 (middle to late 3rd century); T. Linders, The treasurers of the other gods in Atbens and their functions, Meisenheim am Glan, 1975 (Beiträge zur klassiscben Pbilologie, 62), p. 64-65.

269 J.D. Mikalson, Religion in Hellenistic Atbens, Berkeley, Los Angeles, \& London, 1998 (Hellenistic culture and society, 29), p. 53, n. 25 and p. 166.

${ }^{270}$ The text follows Ergon 1961, p. 25, Linders, o.c. (n. 8), p. 71, and ANToniou, o.c. (n. 7), p. 281, no. 4; cf. SEG 37 (1987), no. 89. 
Depending on how the damaged sections are restored, the number of buildings referred to and their relations to each other vary considerably. The difficulty concerns the mutual relations between the naos, the Parthenon, the oiko $i$ and the amphipoleion with its upper floor and to what extent these buildings can be connected with the excavated remains. The restoration of $\Pi \alpha] \rho \theta \varepsilon v o$ ov seems to be beyond doubt and has been unanimously agreed upon. The first word to be restored in the lacuna before the Parthenon begins with an $\alpha$ and Papadimitriou suggested $\alpha \rho \chi \alpha \hat{i o s} .{ }^{271}$ Apparently there is space for more letters between this word and the following Parthenon, and Lily Kahil

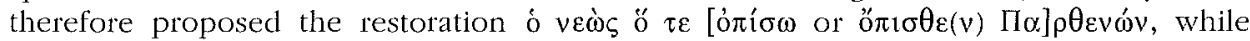

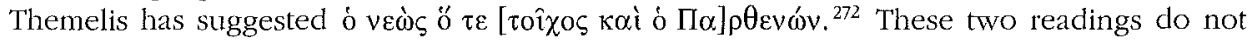
account for the $\alpha$ in front of the lacuna. Recently, Mylonopoulos and Bubenheimer have

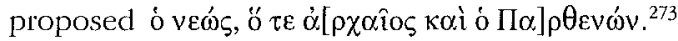

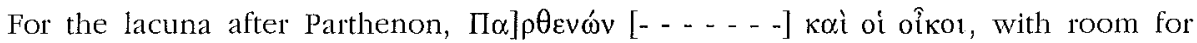
around eight letters, no suggestions have been offered. For the next lacuna, tó $\tau \varepsilon$

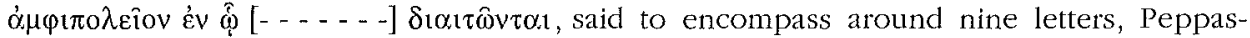

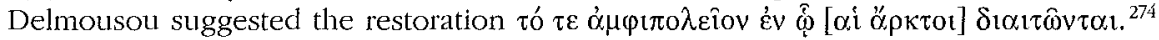

The next problem concerns how this inscription is to be linked to the remains found at Brauron (see Table 3). Most scholars have identified the naos with the main temple at Brauron, i.e. the temple of Artemis. It has also been suggested that naos in this inscription referred only to a part of this building, namely the cella. ${ }^{275}$ Others have proposed that the naos was a building distinct from the large temple known from the excavations, either the so-called "Small Temple" to the south-east at the entrance to the cave or a building situated on the rock-cut terrace to the south, where the church of Ag. Georgios stands today. 276

The Parthenon, in the sense of "the building for the parthenoi", was taken by Papadimitriou as referring to the stoa. Owing to the small sizes of the couches used in the rooms of the stoa, he suggested that the young arktot lived here during their stay at Brauron, while Kondis suggested that the stoa may have functioned as a kind of orphanage. Most scholars today interpret the rooms of the stoa as dining-rooms of the regular kind found in many sanctuaries. ${ }^{277}$ Such rooms are commonly designated as oikoi in texts concerning sanctuaries. The oikol mentioned in the Brauron inscription are therefore best taken to referring to the stoa and, more specifically, the dining-rooms in the northern and western wings.

271 Cf. J. \& L. Robert, "Bulletin épigraphique", REG 76 (1963), p. 134́-135, no. 91, ò vè̀çö $\tau \varepsilon$ $\dot{\alpha}[\rho \chi \alpha \hat{\imath} о \zeta \Pi \alpha] \rho \theta \varepsilon v \omega ́ v$.

272 KAHIL (1977), l.c. (n. 6), p. 96, n. 61, estimating room for around seven letters. Themelis (l.c.

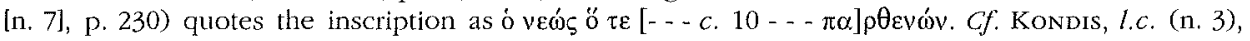
p. 170, n. 55 .

273 Mýlonopoulos \& Bubenheimer, l.c. (n. 50), p. 10-12.

274 Peppas-Delmousou, 1.c. (n. 7), p. 337, n. 49; Robert, l.c. (n. 271), p. 135. For the number of letters, see Themelis, l.c. (n. 7), p. 230. Mylonopoulos \& Bubenheimer (l.c. [n. 50], p. 16-17) suggest that this building must have been used by the priests but offer no restoration of the missing letters.

275 Mylonopoulos \& Bubenheimer, l.c. (n. 50), p. 12-18.

276 "Small Temple": Hollinshead, l.c. (n. 9), p. 434-435. It seems strange, however, that the inventory of the sanctuary should begin with this rather insignificant building. On the naos being located on the rock-cut terrace, see Themelis, l.c. (n. 7), p. 231.

277 On the klinai being of sufficient size for 5th-century, adult, male Athenians, see GoLDsTEIN, o.c. (n. 241), p. 121-122. 
Table 3. Suggested identifications of the buildings mentioned in the 3rd-century inscription.

\begin{tabular}{|c|c|c|c|c|}
\hline Scholar & ó vé́s & {$[\Pi \alpha] \rho \theta \varepsilon v \omega ́ v$} & oi ofkot & 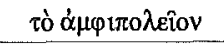 \\
\hline $\begin{array}{l}\text { Papadimitriou (n. 4), } \\
\text { p. 118-120; Ergon 1961, } \\
\text { p. } 25\end{array}$ & $\begin{array}{l}\text { Temple of } \\
\text { Artemis }\end{array}$ & $\begin{array}{l}\text { Stoa where the } \\
\text { arktoi lived? }\end{array}$ & - & - \\
\hline $\begin{array}{l}\text { Robert J. \& L. (n. 271), } \\
\text { p. } 135, \text { no. } 91\end{array}$ & - & $\begin{array}{l}\text { Building for the } \\
\text { partbenoi }\end{array}$ & - & - \\
\hline Bouras (n. 5), p. 75 & Temple & $\begin{array}{l}\text { Stoa where children } \\
\text { stayed }\end{array}$ & $?$ & $?$ \\
\hline $\begin{array}{l}\text { Kondis, (n. 3), p. } 170 \\
\text { and } 180-182\end{array}$ & $\begin{array}{l}\text { Temple of } \\
\text { Artemis }\end{array}$ & $\begin{array}{l}\text { Stoa used as } \\
\text { orphanage }\end{array}$ & Not found yet & Not found yet \\
\hline Börker (n. 5), p. 806 & Temple & $\begin{array}{l}\text { Cult building for } \\
\text { Iphigeneia? }\end{array}$ & $\begin{array}{l}\text { Dining-rooms } \\
\text { of the stoa }\end{array}$ & - \\
\hline Linders (n. 8), p. 71-72 & Temple & $\begin{array}{l}\text { Separate from the } \\
\text { temple but not } \\
\text { identical with the } \\
\text { stoa }\end{array}$ & - & - \\
\hline $\begin{array}{l}\text { Kahil (1977, n. 6), p. 96- } \\
97\end{array}$ & $\begin{array}{l}\text { Temple of } \\
\text { Artemis }\end{array}$ & $\begin{array}{l}\text { Adyton of the } \\
\text { temple }\end{array}$ & $\begin{array}{l}\text { Dining-rooms } \\
\text { of the stoa }\end{array}$ & - \\
\hline $\begin{array}{l}\text { Hollinshead (n. 9), } \\
\text { p. 434-435 }\end{array}$ & Temple ${ }^{278}$ & $\begin{array}{l}\text { Inner room of the } \\
\text { temple, though } \\
\text { name refers to the } \\
\text { whole building }\end{array}$ & $\begin{array}{l}\text { Probably the } \\
\text { rooms of the } \\
\text { stoa }\end{array}$ & - \\
\hline Themelis (n. 7), p. 231 & $\begin{array}{l}\text { Old temple, at } \\
\text { present site of } \\
\text { Ag. Georgios } \\
\text { church } \\
\end{array}$ & Post-Persian temple & $\begin{array}{l}\text { Stoa, used as a } \\
\text { dining-hall }\end{array}$ & Not found yet \\
\hline Brulé (n. 9), p. 245-248 & - & $\begin{array}{l}\text { Adyton of the } \\
\text { temple, "Old } \\
\text { Parthenon" }\end{array}$ & $\begin{array}{l}\text { Rooms of the } \\
\text { stoa }\end{array}$ & - \\
\hline $\begin{array}{l}\text { Peppas-Delmousou } \\
\text { (n. } 7), \text { p. } 337, \text { n. } 49\end{array}$ & - & - & - & Not the stoa \\
\hline Dowden (n. 9), p. 26 & - & $\begin{array}{l}\text { Adyton or small } \\
\text { temple to Iphigeneia }\end{array}$ & - & - \\
\hline $\begin{array}{l}\text { Mylonopoulos \& } \\
\text { Bubenheimer (n. 50), } \\
\text { p. } 12-18\end{array}$ & $\begin{array}{l}\text { Cella of the } \\
\text { temple }\end{array}$ & $\begin{array}{l}\text { Inner room of the } \\
\text { temple }\end{array}$ & $\begin{array}{l}\text { Inner rooms of } \\
\text { the stoa }\end{array}$ & $\begin{array}{l}\text { Section of the } \\
\text { stoa, including a } \\
\text { presumed upper } \\
\text { floor }\end{array}$ \\
\hline
\end{tabular}

If the oikot are the rooms of the stoa or a name for the entire building, the Parthenon has to be sought elsewhere. Its identification is complicated by the fact that the relation of the Parthenon to the noos is particularly difficult to disentangle. The Parthenon has been suggested to be the inner room of the temple, in which valuable dedications were kept and, in this sense, the term may have referred to the whole temple. ${ }^{279}$ It has also been suggested that, while the Parthenon was the term for the inner room of the temple, the cella itself was referred to as the archaios naos. ${ }^{280}$ However, some of the 4th-century

${ }^{278}$ Hollinshead (l.c. [n, 9], p, 434-435) makes a distinction between the temple mentioned in this inscription and the Old Temple mentioned in the inventories of offerings, which she identifies with the "Small Temple".

279 Inner room: KaHLL (1977), l.c. (n. 6), p. 96-97; Hollinshead, l.c. (n. 9), p. 434-435; BrulÉ, o.c. (n. 9), p. 247-248; Dowden, o.c. (n. 9), p. 26; MYlonopoulos \& Bubenheimer, l.c. (n. 50), p. 12-15. Whole building: Hollinshead, l.c. (n. 9), p. 434-435; Themelis, l.c. (n. 7), p. 231.

280 Mylonopoulos \& Bubenheimer, l.c. (n. 50), p. 12-15. 
inventories concerning Brauron also mention an Old Temple and a Parthenon and, in those cases, it seems clear that they constituted two separate entities and presumably also two separate buildings. ${ }^{281}$ It seems plausible that the two terms "Old Temple" and "Parthenon" would have been used in a similar manner in the 3rd century and therefore naos or archaios naos and Parthenon are best connected with two separate buildings. Themelis' suggestion that the Old Temple may have stood on the rock-cut terrace, today housing the small church, while the Parthenon is to be identified with the post-Persian temple, may be a possible solution. ${ }^{282}$ Finally, it has been proposed that the Parthenon may have been a cult building for Iphigeneia and is to be identified with the so-called "Small Temple". ${ }^{283}$

The amphipoleion with its upper floor is even more complex and has either been left without any comment or simply been located outside the excavated area. This building may have housed the religious office-holders, but it has also been suggested that the arkto lived there, perhaps on the upper floor, while cult equipment was kept downstairs. ${ }^{284}$ Since the amplipoleion is said to have had an upper floor, any links with the stoa have been excluded. Recently, it has been suggested that the stoa is to be identified with the amphipoleion, since it may have had an upper floor after all, the lack of evidence for which being simply due to an accidental state of preservation. ${ }^{285}$

The existence of a gymnasium, a palestra and stables, also mentioned in the inscription, offers no textual difficulties. All of these apparently remain to be discovered, most likely to the west or to the east of the sanctuary. ${ }^{286}$ Finally, there are the structures

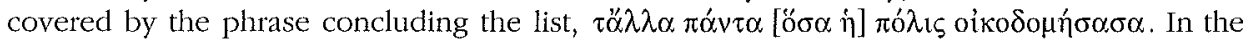
3rd century, the cave itself had, of course, long since been abandoned and the same probably also went for the "Sacred House". The building at the north-western entrance of the cave, the "Small Temple", is likely to have gone out of use by this period, but, if it was still functioning, it may have been included in this phrase. ${ }^{287}$ In any case, the "Small Temple" was apparently not considered as being of such importance that it merited a particular mention in the inventory of the sanctuary, unlike the stables, for example. ${ }^{288}$

281 LiNDERs, o.c. (n. 8), p. 71-72, cf. 52-53. In $I G \mathrm{II}^{2}, 1524,44-47$ (353/2 BC), objects kept in the Old Temple are handed over by the priestess to the epistatai and placed in the Parthenon.

282 Themelis, l.c. (n. 7), p. 231.

283 Börker, l.c. (n. 5), p. 806; DOWDEN, O.C. (n. 9), p. 26.

284 Brulé, o.c. (n. 9), p. 245-248; Dowden, o.c. (n. 9), p. 38; Mylonopoulos \& Bubenheimer, l.c. (n. 50), p. 16-17; Peppas-Delmousou, l.c. (n. 7), p. 336-337. On the ampbipoloi referring to older, former bears assisting in the arkteia, see Sourvinou-INwood (1988), o.c. (n. 17), p. 106-108; cf. S.

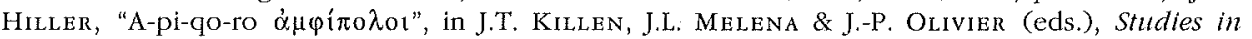
Mycenaean and Classical Greek presented to Jobn Chadwick, Salamanca, 1987 (= Minos 20-22), demonstrating that the original meaning of ampbipolos was a servant of an earthly or heavenly mistress.

285 Mylonopoulos \& Bubenheimer, l.c. (n. 50), p. 18.

286 To the east of the late-5th-century stoa, a 30-m-long wall, oriented north-south, was discovered, perhaps to be connected with one or more of these buildings (see Ergon 1962, p. 31). For the suggestion that the stables are to be identified with the northern section of the stoa, see above, n. 156. Apart from the architectural difficulties of such an interpretation, it seems strange that the stables should not have been mentioned in connection with the stoa, had they been part of this building. Stables are mentioned also in another inscription from Brauron; see Ergon 1961, p. 24; SEG 37 (1987), no. 35.

287 Mylonopoulos \& Bubenheimer (l.c. [n. 50], p. 21) suggest that this phrase may refer to the "Small Temple", the "Sacred House" and the bridge.

288 Unless the "Small Temple" is to be identified with the Parthenon; see above, n. 283. Another structure not mentioned is the mid-5th-century bridge located to the west of the stoa. This may also have gone out of use in the 3rd century, perhaps covered by soil or mud from the Erasinos. 


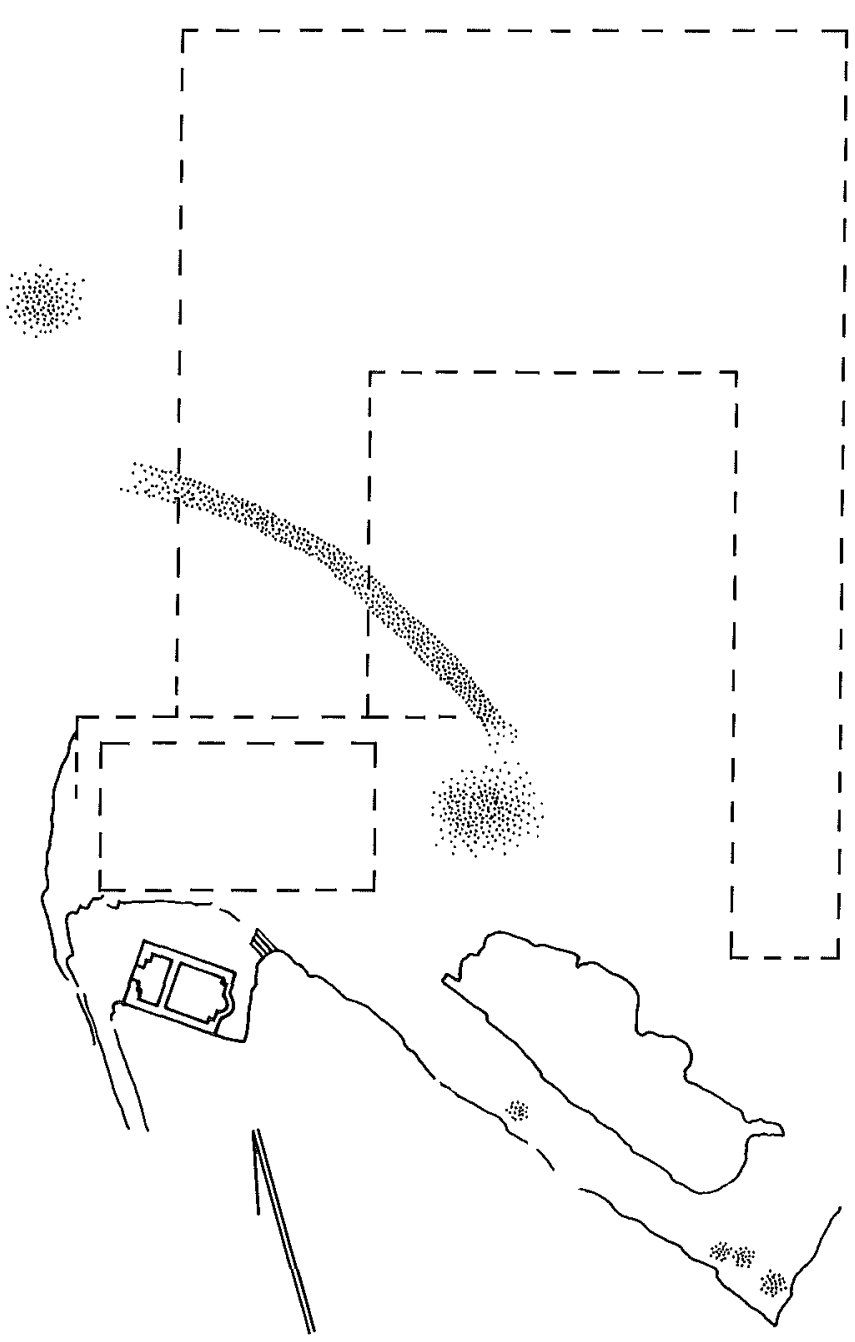

Fig. 10. Brauron, Roman and Byzantine periods.

The stippling indicates approximate areas with traces of Roman and Christian activity.

Phase 5: The Roman and Byzantine periods (Fig. 10)

By the Roman period, Brauron may have been completely deserted and contemporary sources, such as Pomponius Mela, speak of the sanctuary as not being in operation. ${ }^{259}$ The changes that had taken place are most clearly illustrated by the four graves which were found in the cave area and which most likely date from the 2nd century $\mathrm{AD}$, when the site had long been abandoned as a living sanctuary. ${ }^{290}$ It is interesting to note that several fragments of a large relief showing Polydeukion, one of the

289 Pomponius Mela, II, 46. For the suggestion that the temple may have been moved in Augustan times, see supra, n. 246.

290 For these graves, see above, p. 77-78. 
favourites of Herodes Atticus, were recovered to the east of the stoa. ${ }^{291}$ The young man, who died around $\mathrm{AD} 165$, was depicted as a reclining banqueter, a scheme commonly used for funerary monuments in the Hellenistic and Roman periods. Perhaps the whole area had, by this time, acquired some kind of funerary function. ${ }^{292}$

Some time after the $3 \mathrm{rd}$ century $\mathrm{BC}$, though probably at a considerably later date, a paved road was constructed over the western wing of the stoa ${ }^{293}$ The paving was made up by architectural parts from the stoa itself and by reliefs, sculptures and inscriptions. To the north-west of the former stoa was discovered a deposit of similar material, which apparently had been accumulated at this spot to facilitate its removal. The road led from the north-west to the south-east towards the open area in front of the temple and parts of the northern side of the temple seem to have been removed for it. The date of the road is hard to ascertain, but it seems unlikely that it predated the desertion of the sanctuary in Roman times. Perhaps both the plundering of the sanctuary for building stones and the laying out of the road are to be connected with the construction in the 6th century AD of a large Christian basilica $c .1 .5 \mathrm{~km}$ to the west, since this structure definitely incorporates a number of blocks from the sanctuary. ${ }^{29 i}$ In the Christian period, the area of the former sanctuary may have housed some kind of habitation, judging from a series of four large pithoi excavated in front of the temple, and the road can maybe also be linked to this activity. ${ }^{295}$ The latest activity on the site was the construction of the small, post-Byzantine chapel of Aghios Georgios in the 15th century $\mathrm{AD}$, which also incorporated re-used blocks from the sanctuary. ${ }^{296}$

291 Ergon 1961, p. 35-36, fig. 39; Ergon 1962, p. 32-33, fig. 42; found only $0.50 \mathrm{~m}$ below the modern ground surface. Polydeukion was not buried at Brauron, but Herodes Atticus erected a number of monuments to him in this part of Attica after his death; see W. Ameling, Herodes Atticus, vol. 1, Biograpbie, Hildesheim, 1983 (Subsidia epigraphica, 11), p. 114-117; Id., Herodes Atticus, vol. 2, Inscbriftenkatalog, Hildesheim, 1983 (Subsidia epigrapbica, 11), p. 166-172, nos. 171-176.

292 If the four burials are to be dated to the 2nd century $A D$ and are therefore contemporary with the Polydeukion monument, they may all be connected with the plague which swept Greece in the middle of this century; see J.F. Gilliam, "The plague under Marcus Aurelius", $A J P h$ 82 (1961), p. 225-251. The death of Polydeukion, as well as the sudden deaths of two other young favourites of Herodes Atticus, have been suggested to be connected with this disease; see Ameling, o.c. (n. 291), vol. 1, p. 114.

293 Ergon 1960, p. 23-24, figs. 31 and 36; Ergon 1961, p. 27-28; Bouras, o.c. (n. 5), p. 169-170.

294 Bouras, o.c. (n. 5), p. 169. This basilica was destroyed in the 7th century; see Themelis (1974), o.c. (n. 49), p. 28-30.

295 PAAH 1956, p. 73-75, pl. 18 g; Ergon 1956, p. 25. The whole area to the east of the temple had been heavily disturbed in the Christian period.

296 Eigon 1960, p. 28-29; Themelis (1974), o.c. (n. 49), p. 28-30. 